September 2004 - NREL/TP-500-36551

\title{
Wind Power Plant Behaviors: Analyses of Long-Term Wind Power Data
}

\author{
Yih-Huei Wan
}

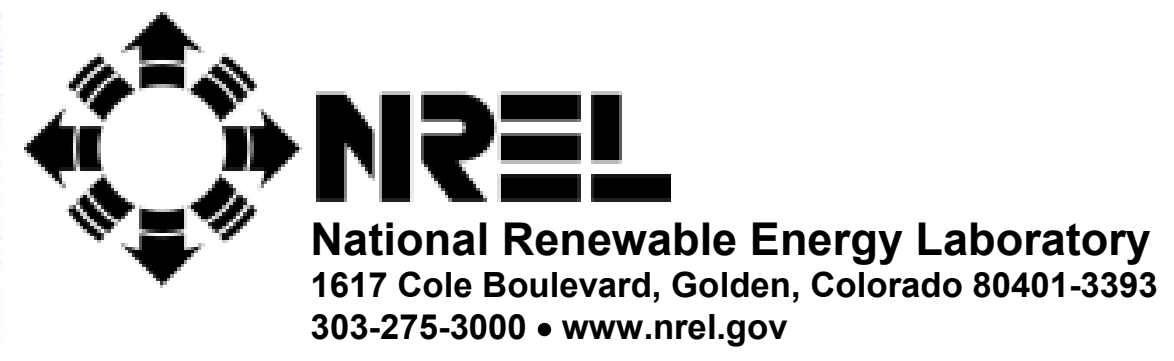

Operated for the U.S. Department of Energy Office of Energy Efficiency and Renewable Energy by Midwest Research Institute $\bullet$ Battelle 


\section{Wind Power Plant Behaviors: Analyses of Long-Term Wind Power Data}

\section{Yih-Huei Wan}

Prepared under Task No. WER4.4001

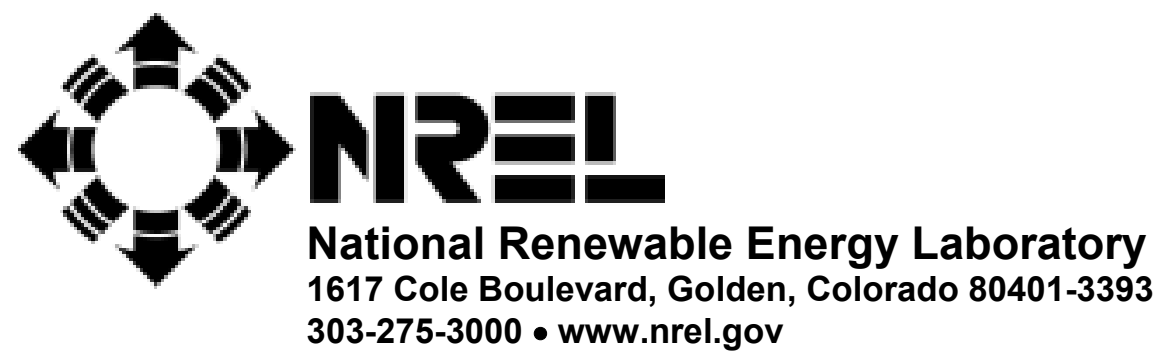

Operated for the U.S. Department of Energy Office of Energy Efficiency and Renewable Energy

by Midwest Research Institute • Battelle

Contract No. DE-AC36-99-G010337 


\section{NOTICE}

This report was prepared as an account of work sponsored by an agency of the United States government. Neither the United States government nor any agency thereof, nor any of their employees, makes any warranty, express or implied, or assumes any legal liability or responsibility for the accuracy, completeness, or usefulness of any information, apparatus, product, or process disclosed, or represents that its use would not infringe privately owned rights. Reference herein to any specific commercial product, process, or service by trade name, trademark, manufacturer, or otherwise does not necessarily constitute or imply its endorsement, recommendation, or favoring by the United States government or any agency thereof. The views and opinions of authors expressed herein do not necessarily state or reflect those of the United States government or any agency thereof.

Available electronically at http://www.osti.gov/bridge

Available for a processing fee to U.S. Department of Energy and its contractors, in paper, from:

U.S. Department of Energy

Office of Scientific and Technical Information

P.O. Box 62

Oak Ridge, TN 37831-0062

phone: 865.576.8401

fax: 865.576.5728

email: mailto:reports@adonis.osti.gov

Available for sale to the public, in paper, from:

U.S. Department of Commerce

National Technical Information Service

5285 Port Royal Road

Springfield, VA 22161

phone: 800.553 .6847

fax: 703.605.6900

email: orders@ntis.fedworld.gov

online ordering: http://www.ntis.gov/ordering.htm 


\section{Table of Contents}

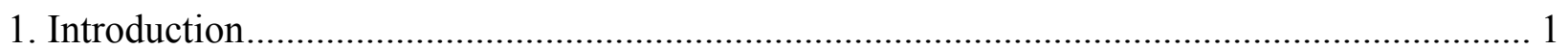

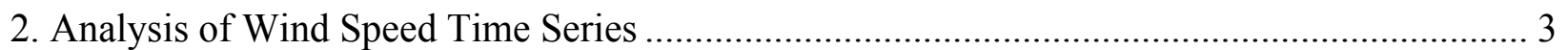

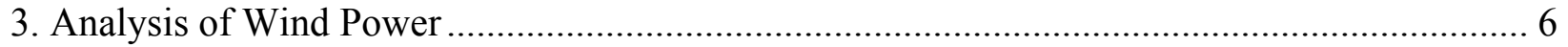

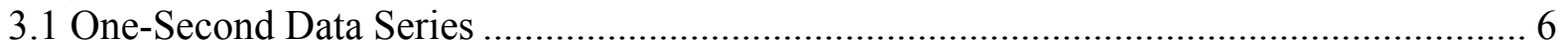

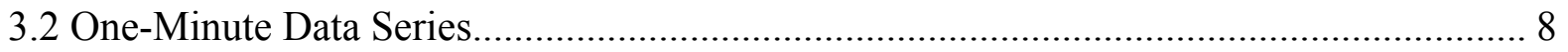

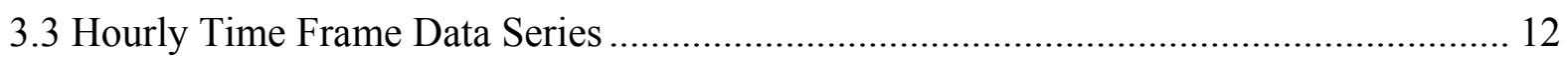

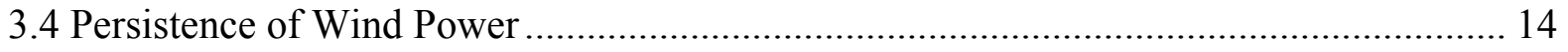

3.5 Daily Wind Power Profile......................................................................................... 16

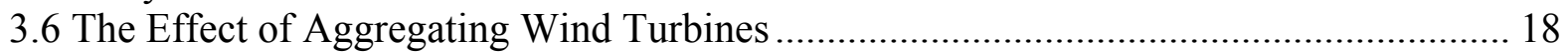

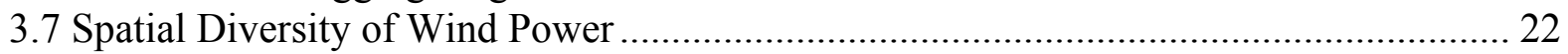

3.7.1 Output Correlation between Adjacent Wind Power Plants ..................................... 23

3.7.2 Output Correlation between Distant Wind Power Plants ......................................... 25

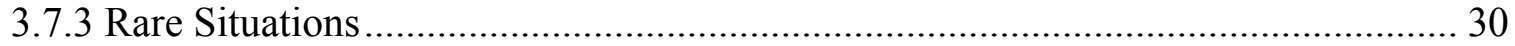

4. Long-Term Statistics of Wind Power ………………............................................................... 33

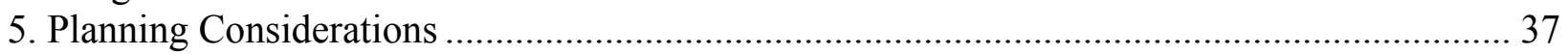

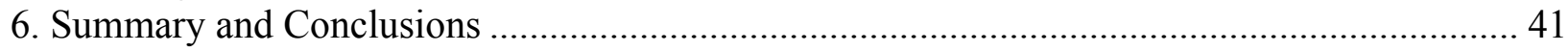

APPENDIX A. Statistics of Wind Power Step Changes with 1-Second Data Series ................... 42

APPENDIX B. Statistics of Wind Power Step Changes with 1-Minute Data Series..................... 45

APPENDIX C. Statistics of Wind Power Step Changes with 10-Minute Data Series ................... 48

APPENDIX D. Statistics of Wind Power Step Changes with 1-Hour Data Series ........................ 51

APPENDIX E. Statistics of Wind Power Ramping Rates with 1-Minute Data Series ................. 54

APPENDIX F. Links to Related Studies ................................................................................... 57 


\section{List of Tables}

Table 1. Distances between Midwest and Texas Wind Power Plants ..................................... 2

Table 2. Monthly Statistics of 1-Minute Step Changes ............................................................ 10

Table 3. Monthly Ramping Statistics with 1-Minute Average Power Data ............................... 11

Table 4. Average and Extreme Values of Wind Power Hourly Step Changes .......................... 13

Table 5. Average and Extreme Ramping Rates with Hourly Wind Power................................ 14

Table 6. State Transition Rates with 1-Second Power Data ……………………………........... 15

Table 7. State Transition Rates with 1-Minute Average Power Data........................................ 15

Table 8. State Transition Rates with Hourly Average Power Data ............................................. 16

Table 9. Average Magnitudes of 1-Minute Step Changes of Turbine Groups ………................ 20

Table 10. Average Magnitudes of Ramping Rates and Ramping Periods.................................. 21

Table 11. Average Magnitudes of 1-Minute Step Changes of Scaled-Up Data .......................... 21

Table 12. 1-Minute and 1-Hour Step Changes of Texas Wind Power Plants.............................. 26

Table 13. 1-Minute and 1-Hour Ramping Rates of Texas Wind Power Plants .......................... 27

Table 14. Effect of Aggregating Wind Power ............................................................................. 27

Table 15. Monthly Average Correlation Coefficients of Powers among Texas Wind Power Plants............................................................................................... 28

Table 16. Monthly Average Correlation Coefficients of Powers from Texas and Midwest

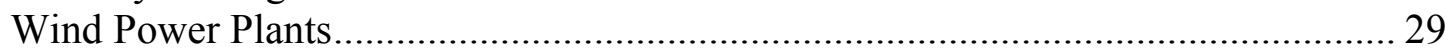

Table 17. Distribution of 10-Minute Wind Power Step Changes as Percentage of Plant Capacity 36 


\section{List of Figures}

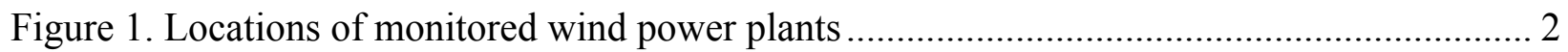

Figure 2. 1-minute average wind speed of a 24-hour period .................................................... 3

Figure 3. 1-minute average wind speed in a 60 -minute window .................................................. 4

Figure 4. Frequency distribution of wind speed positive and negative ramping periods ............... 5

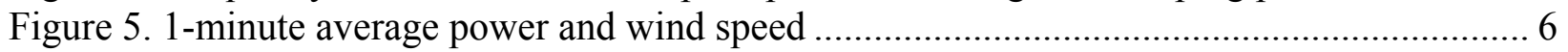

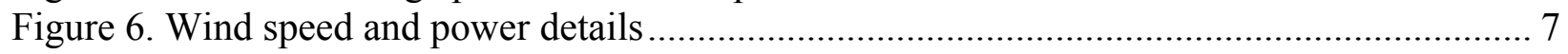

Figure 7. Distribution of 1 -second step change values ................................................................. 7

Figure 8. Distribution of ramping rate and step changes values................................................ 9

Figure 9. Distribution of monthly step changes and ramping rates .......................................... 12

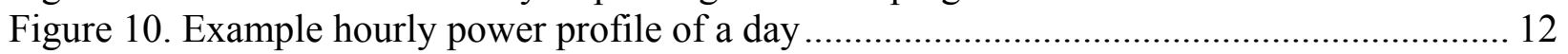

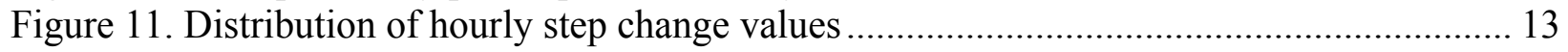

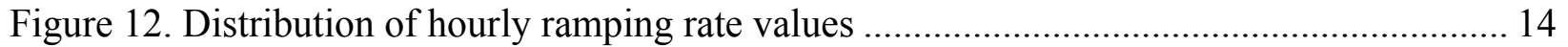

Figure 13. Average hourly power profile for the month of August............................................. 17

Figure 14. Average hourly power profiles of spring months ........................................................ 17

Figure 15. Average hourly power profiles of winter months................................................. 17

Figure 16. Average hourly power profiles of fall months ........................................................... 18

Figure 17. Average hourly power profiles of summer months .................................................. 18

Figure 18. Distribution of correlation coefficients of three time intervals ................................... 20

Figure 19. Distribution of correlation coefficients between SW Minn. and Storm Lake.............. 23

Figure 20. Correlation of daily outputs between SW Minn. and Storm Lake ............................... 24

Figure 21. Example of weekly 1-minute average power from SW Minn. and Storm Lake ......... 24

Figure 22. Cross-correlation between SW Minn. and Storm Lake............................................ 25

Figure 23. Example daily output profiles of four Texas wind power plants ................................ 26

Figure 24. Example of hourly output profiles of Midwest and Texas wind power plants ........... 30

Figure 25. Example of wind power during high wind period........................................................ 31

Figure 26. Detail of turbine cut-off with 1-second power data series .......................................... 32

Figure 27. Example of wind power outage .............................................................................. 34 


\section{Introduction}

In the past 20 years, U.S. wind power capacity has increased continuously. With the federal tax credit and the emerging green market, total installed wind power capacity in the United States exceeds 6,000 MW. However, the industry's growth continues to be hampered by many market barriers, some of which stem from utilities' lack of experience with the technology. The effects of wind power fluctuations on power system operations and requirements of ancillary services for wind power have increasingly become concerns for many electric utilities and wind power developers.

Large-scale installation of wind power faces more scrutiny because of its unique characteristics. Wind power output varies with wind speed. A single wind power plant may have many relatively small induction generators that behave differently than conventional central-station power plants with large synchronous generators. Utility system operators and planners need to understand the effects of fluctuating wind power on system regulation and stability. Without high-frequency wind power data and realistic wind power plant models to analyze the problem, utilities often rely on conservative assumptions and worst-case scenarios to make engineering decisions.

To remedy the situation, the National Renewable Energy Laboratory (NREL) has undertaken a project to record long-term, high-resolution (1-hertz [Hz]) wind power output data from large wind power plants in various regions. The objective is to systematically collect actual wind power data from large commercial wind power plants so that wind power fluctuations, their frequency distribution, the effects of spatial diversity, and the ancillary services requirements of large commercial wind power plants can be analyzed. It also aims to provide the industry with nonproprietary wind power data in different wind regimes for system planning and operating impact studies.

Under NREL's wind power plant monitoring project, data are being collected at seven locations. The locations and total installed capacity of the monitored plants are listed here. Figure 1 shows the locations of wind power plants. The distances between these plants are shown in Table 1 .

1. Wind power plant at southwest Minnesota (SW Minn.). It encompasses 138 turbines, each rated at 750 kilowatts $(\mathrm{kW})$ for a total installed capacity of 103.5 megawatts (MW). Four 34.5-kilovolt $(\mathrm{kV})$ lines collect the power and feed it into the local utility's nearby transmission network through a substation. Data recording equipment is installed at these interconnection points to collect data.

2. Wind power plant in northwestern Iowa near Storm Lake, Iowa. It has 151 Zond Z50 turbines with a total installed wind power capacity of $113.25 \mathrm{MW}$.

3. Buffalo Ridge Substation in southwestern Minnesota. The substation receives wind power from five wind power plants of various sizes and turbine types with a total capacity of about $230 \mathrm{MW}$. All five wind power plants are located along a topographic feature known as Buffalo Ridge

4. Wind power plant in southwest Upton County, Texas (SW Upton). It has 214 Bonus 1.3MW turbines. The output of 61 of the 214 turbines (a capacity of $79.3 \mathrm{MW}$ ) is monitored. 
5. Wind Power plant in south Upton County, Texas (S Upton). It has 125 Vestas V47 660-kW turbines. The total installed capacity is $82.5 \mathrm{MW}$.

6. Trent Mesa Wind Project (Trent Mesa), in Taylor County near Abilene, Texas, consists of 100 GE 1.5-MW turbines for a capacity of $150 \mathrm{MW}$.

7. Texas Wind Power Project (TWPP), in Culberson County, Texas (located about 100 miles east of El Paso), consists of 112 Kenetech 330-kW turbines with a capacity of 35 MW.

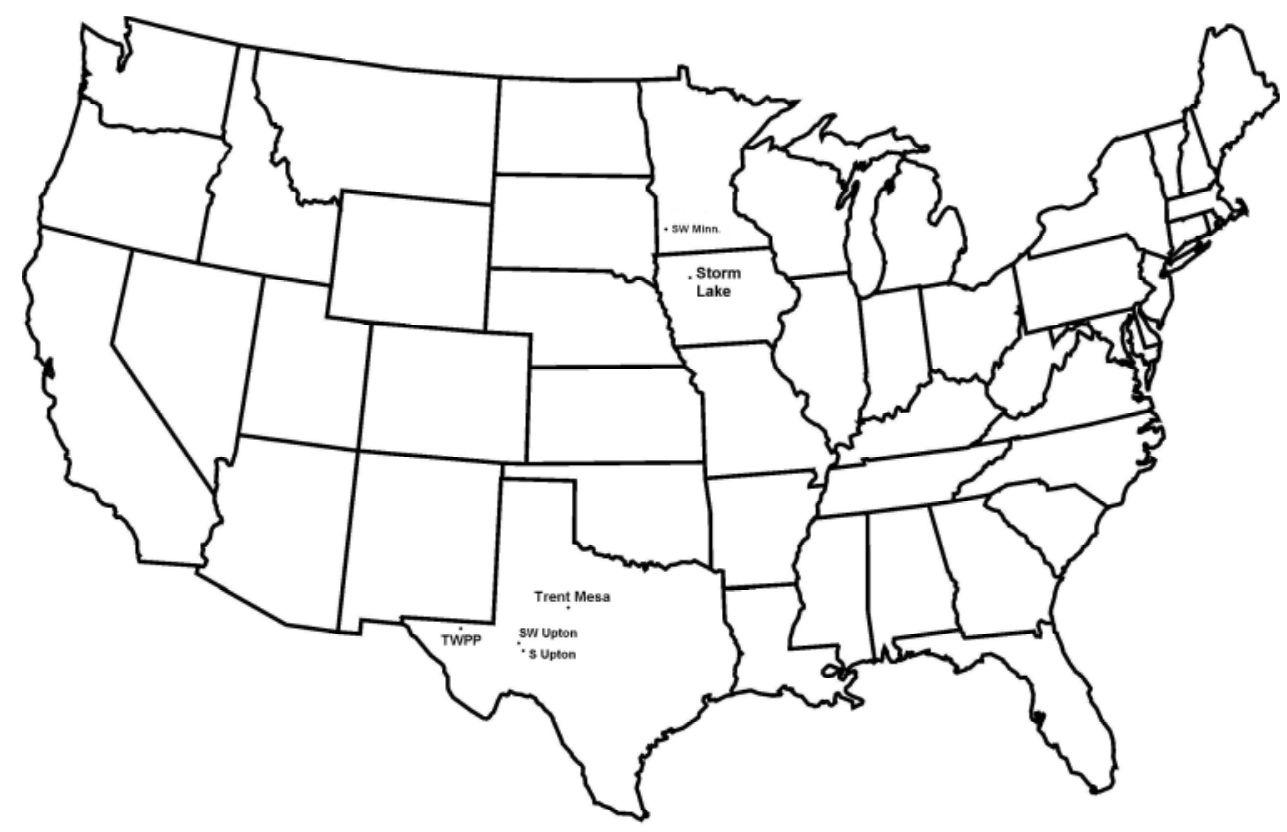

Figure 1. Locations of monitored wind power plants

Table 1. Distances between Midwest and Texas Wind Power Plants

\begin{tabular}{|l|c|c|c|c|c|}
\hline Distance (km) & SW Upton TX & S Upton TX & TWPP & SW Minn. & Storm Lake \\
\hline Trent Mesa & 270 & 290 & 490 & 1,370 & 1,200 \\
\hline SW Upton TX & & 40 & 260 & 1,540 & 1,410 \\
\hline S Upton TX & & & 280 & 1,580 & 1,450 \\
\hline TWPP & & & & 1,590 & 1,480 \\
\hline SW Minn. & & & & & 200 \\
\hline
\end{tabular}

The power data are recorded at $1 \mathrm{~Hz}$. One-minute average wind speeds at hub height are also recorded from an on-site meteorological tower at the SW Minn. wind power plant. From the recorded 1-second and 1-minute data series, 1-minute, 10-minute, and 1-hour time series wind power and wind speed data are compiled for analysis.

The industry has used a large amount of data collected for various system integration studies. Links to some of the reports are listed in the Appendix. This report will summarize the results of data analysis performed at NREL and discuss the wind power characteristics related to power system operation and planning. The goal is to help utility planners and operators who have not had experience with wind power in their systems to better understand wind power plant behavior. 


\section{Analysis of Wind Speed Time Series}

This report focuses on the behavior of large wind plant output, so it will only briefly discuss those wind attributes that directly affect short-term wind power fluctuations. The wind speed attributes of interest are average, standard deviation, step changes, and ramping rates over different time scales. The following example illustrates these attributes.

Figure 2 plots 1-minute average wind speeds at turbine hub height $(50 \mathrm{~m})$ over a 24-hour period (total 1440 data points) from the wind power plant at SW Minnesota. During this period, wind speed varies from $4.43 \mathrm{~m} / \mathrm{s}$ to $13.03 \mathrm{~m} / \mathrm{s}$ and averages at $8.63 \mathrm{~m} / \mathrm{s}$. The jagged appearance of the wind speed plot is typical for the time scale used in the figure. The wind speed changes continuously, and the short-term changes are stochastic. In a much longer time frame, such as days or months, the wind may display distinct diurnal cycles or seasonal variations, but those features will not be considered here.

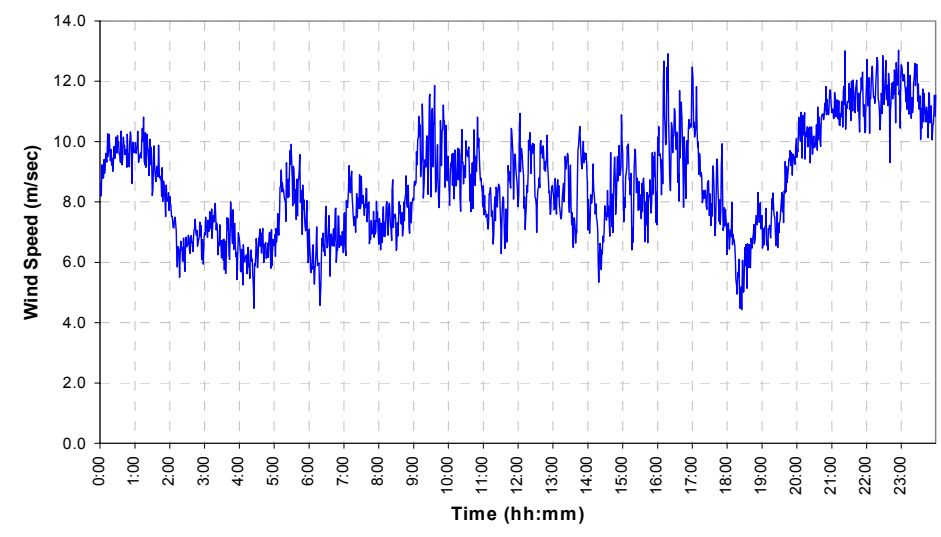

Figure 2. 1-minute average wind speed of a 24-hour period

In addition to mean and standard deviation values of wind speed over a specific period, wind speed ramping or rate of change influences plant output. In this report, wind speed ramping or rate of change is defined as the differences of wind speeds over a chosen period divided by the duration or period. Wind speed step change (i.e., wind speed differences from one minute to the next) is one way to look at wind speed ramping - how fast the wind speed can change in one time step in the time series. This measure gives an outer boundary of wind speed ramping. For sustained rates of change, longer periods are chosen. In this report, these are subperiods of the wind speed time series during which the wind speeds either increase or decrease monotonically. The average rate of wind speed change - wind speed difference of the subperiod divided by the subperiod length - is used to represent the ramping rates of each subperiod. 


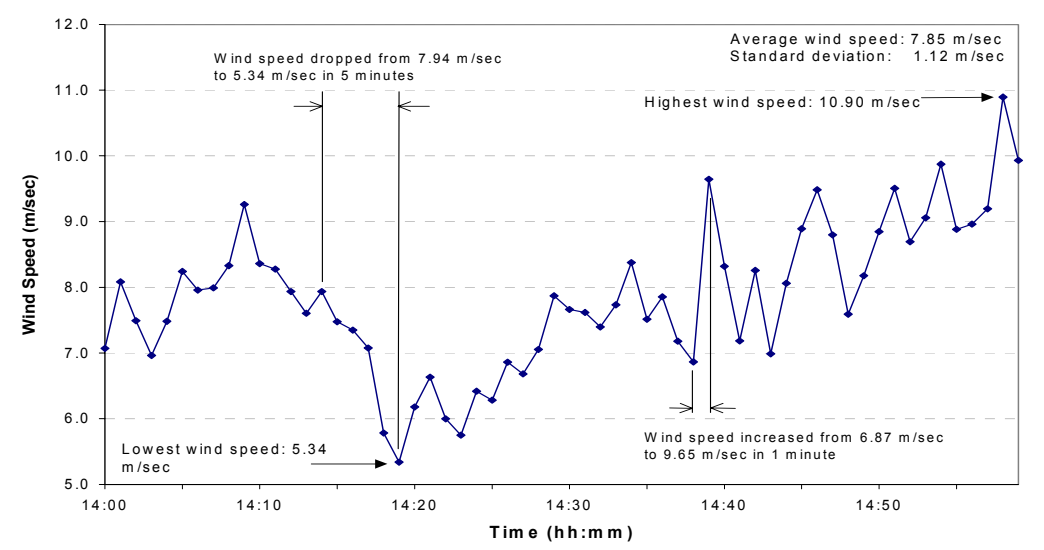

Figure 3.1-minute average wind speed in a 60-minute window

The plot in Figure 3 illustrates these two methods of examining wind speed ramping. It also provides a clearer view of wind speed short-term changes, 1 hour of the 1-minute wind speed time series (60 data points from 14:00 to 14:59). The average wind speed during this period is $7.85 \mathrm{~m} / \mathrm{s}$ with a standard deviation of $1.12 \mathrm{~m} / \mathrm{s}$. It yields a coefficient of variance (COV, or standard deviation divided by average) of 0.14 . The largest 1-minute wind speed change is 2.78 $\mathrm{m} / \mathrm{s}$ (so the rate is $2.78 \mathrm{~m} / \mathrm{s}^{2}$ ) in the positive direction (increasing), and the largest 1-minute wind speed change in the negative direction is $-1.33 \mathrm{~m} / \mathrm{s}$ (for a rate of $-1.33 \mathrm{~m} / \mathrm{s}^{2}$ ), but their average values are small: $0.70 \mathrm{~m} / \mathrm{s}$ in the positive direction and $-0.59 \mathrm{~m} / \mathrm{s}$ in the negative direction.

Sixteen subperiods range from 1 to 3 minutes in length, during which the wind speed increases monotonically. These are called positive ramping periods in this report. Also, 16 subperiods, called negative ramping periods, range from 1 to 5 minutes, in which the wind speed decreases monotonically. In Figure 3, the largest positive ramping occurred in 1 minute (when wind speed increased by $2.78 \mathrm{~m} / \mathrm{s}$ ) and the largest negative ramping occurred in 5 minutes (when wind speed decreased by $2.60 \mathrm{~m} / \mathrm{s}$ ), for an average rate of $-0.52 \mathrm{~m} / \mathrm{s}^{2}$. The longest negative ramping period in Figure 3 is 5 minutes. The longest positive ramping period in Figure 3 is 3 minutes. Most positive and negative periods last 1 minute. During this 60 -minute period, the average length of positive ramping periods is 1.8 minutes, and the average length of negative ramping periods is 1.9 minutes. This method yields an average positive ramping rate of $0.77 \mathrm{~m} / \mathrm{s}^{2}$ and an average negative ramping rate of $-0.64 \mathrm{~m} / \mathrm{s}^{2}$.

For the 24-hour period shown in Figure 3, the average wind speed is $8.63 \mathrm{~m} / \mathrm{s}$ with a standard deviation of $1.75 \mathrm{~m} / \mathrm{s}$ (for a COV of 0.20 ). There are 712 positive steps (wind speed is higher in the next minute), and the average of all positive step changes is $0.58 \mathrm{~m} / \mathrm{s}$. There are 727 negative steps (wind speed is lower in the next minute), and the average value of all negative step changes is $-0.56 \mathrm{~m} / \mathrm{s}$. The largest 1 -minute increase of wind speed is $3.68 \mathrm{~m} / \mathrm{s}$, and the largest 1 -minute decrease in wind speed is $-2.60 \mathrm{~m} / \mathrm{s}$. 
There are 431 positive ramping periods and 430 negative ramping periods during this 24 -hour period. Figure 4 plots the frequency distribution of positive and negative periods. The longest positive ramping period is 5 minutes, and the longest negative ramping period is 7 minutes. Average lengths for positive and negative periods are of the same value at 1.7 minutes. Figure 4 shows that $85 \%$ of all ramping periods are shorter than 2 minutes. Calculated this way, the average positive ramping rate and negative ramping rate are $0.62 \mathrm{~m} / \mathrm{s}^{2}$ and $-0.60 \mathrm{~m} / \mathrm{s}^{2}$, respectively. They are very close to the average positive and negative step change values.

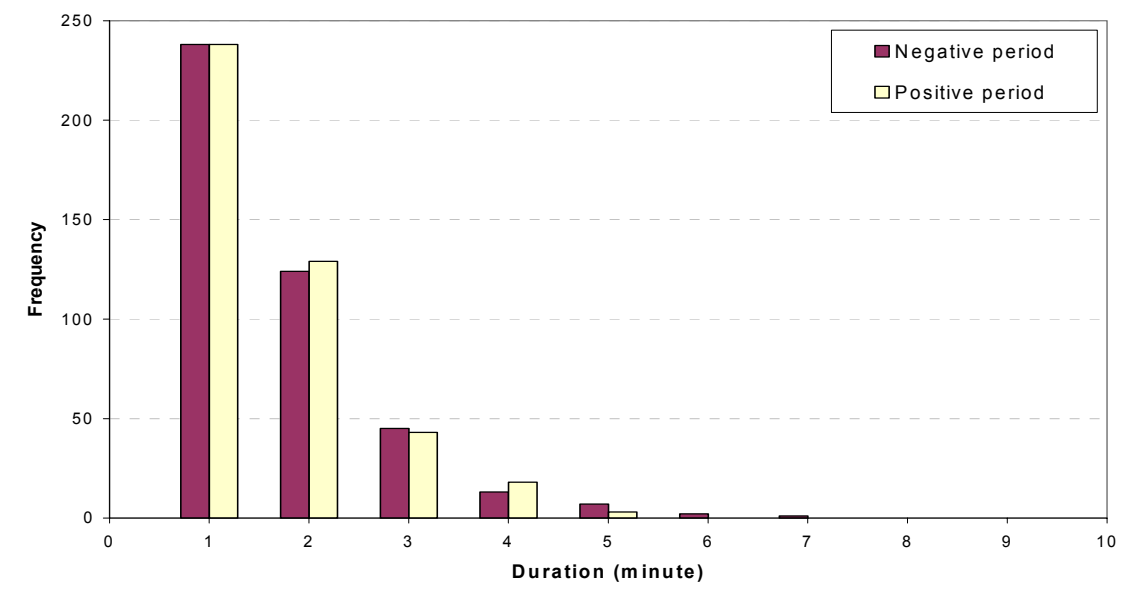

Figure 4. Frequency distribution of wind speed positive and negative ramping periods 


\section{Analysis of Wind Power}

To see how wind power plant output relates to the wind speed variations, the step changes and ramping rates from 1-minute wind power series for the same 24-hour period are analyzed. Figure 5 is the wind speed plot shown in Figure 1 with 1-minute average output power from the SW Minnesota wind power plant. The scale for the power is on the right side of the graph. As previously noted, the total installed capacity at SW Minnesota wind power plant is $103.5 \mathrm{MW}$. The power trace in Figure 5 follows the general trend of wind speed closely, but it appears to be smoother. It suggests that short-term fluctuations of output power may be less than those of wind speed. The rest of this section will focus on analyzing wind power data series at different time frames.

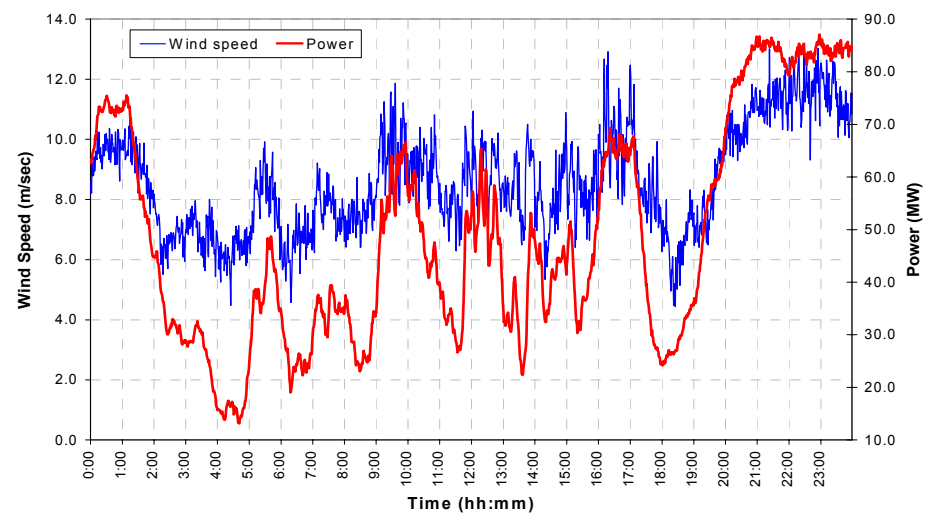

Figure 5. 1-minute average power and wind speed

\subsection{One-Second Data Series}

A 1-hour time series of 1-minute average wind speed and wind power in Figure 5 is redrawn in Figure 6 (the same 60-minute period as in Figure 3) for a clearer view of the relation between wind speed and plant output. Overlaying the 1-minute average power trace in Figure 6 is 1second data used to calculate the 1-minute average power. The process of averaging smoothes out many of the zigzags in the 1-second data series. During this 1-hour period, the 1-minute power ranges from 32.4 MW to $47.9 \mathrm{MW}$, with an average value of $41.4 \mathrm{MW}$ and a standard deviation of 4.4 MW. These values yield a COV of 0.11 , which is less than wind speed COV during the same period. It supports the observation that wind power is less variable than wind during this period. This relation is somewhat unusual. The COV for wind power is expected to be greater than the COV of wind speed because the available power from wind is proportional to the wind speed cubed. ${ }^{1}$ A small change in wind speed translates to a large change in available power. This will be discussed in greater detail later.

\footnotetext{
${ }^{1}$ Available power from wind is $1 / 2 \rho \mathrm{Av}^{3}$ [1], where $\rho$ is air density, $\mathrm{A}$ is the area of turbine rotor disk, and $\mathrm{v}$ is wind speed.
} 


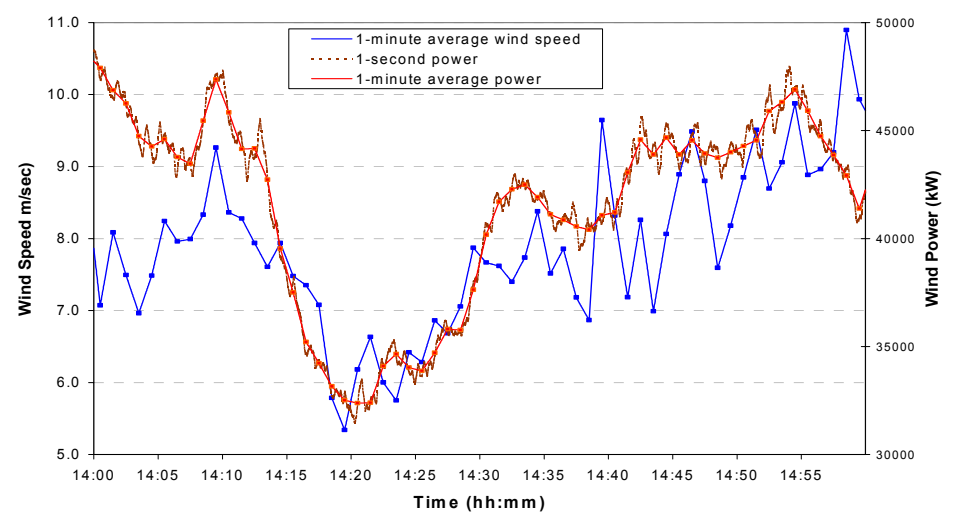

Figure 6. Wind speed and power details

The average of all 1-second positive step changes during this hour is $64 \mathrm{~kW}$, and the average of all negative step changes is $-66 \mathrm{~kW}$. The largest 1 -second power increase during this hour is 320 $\mathrm{kW}$, and the largest 1 -second power decrease is $-332 \mathrm{~kW}$. The average of the magnitude of all step changes (i.e., absolute differences between consecutive 1-second power values) is $65 \mathrm{~kW}$. These values are small compared to the installed capacity of 103.5 MW and average output of 47.9 MW during this hour. For the 24-hour period, the average magnitude of 1-second step changes is $104 \mathrm{~kW}$ (positive steps average $105 \mathrm{~kW}$; negative steps average $-104 \mathrm{~kW}$ ). The monthly average magnitudes of 1-second step changes range from a low of $50 \mathrm{~kW}$ to a high of $133 \mathrm{~kW}$ for the 3-year period during which the wind power data from SW Minnesota wind power plant are available. The largest 1-second power level change is $4 \mathrm{MW}$ (magnitude), but such a large step change rarely occurs. Figure 7 shows the frequency distributions of 1-second step changes expressed in terms of wind power plant installed capacity for three time frames: 1hour, 24-hour, and 1-month. To reconcile the tremendous differences in the numbers of 1second steps in the three time frames, the frequencies in the figure are normalized by the total numbers of steps of each time frame.

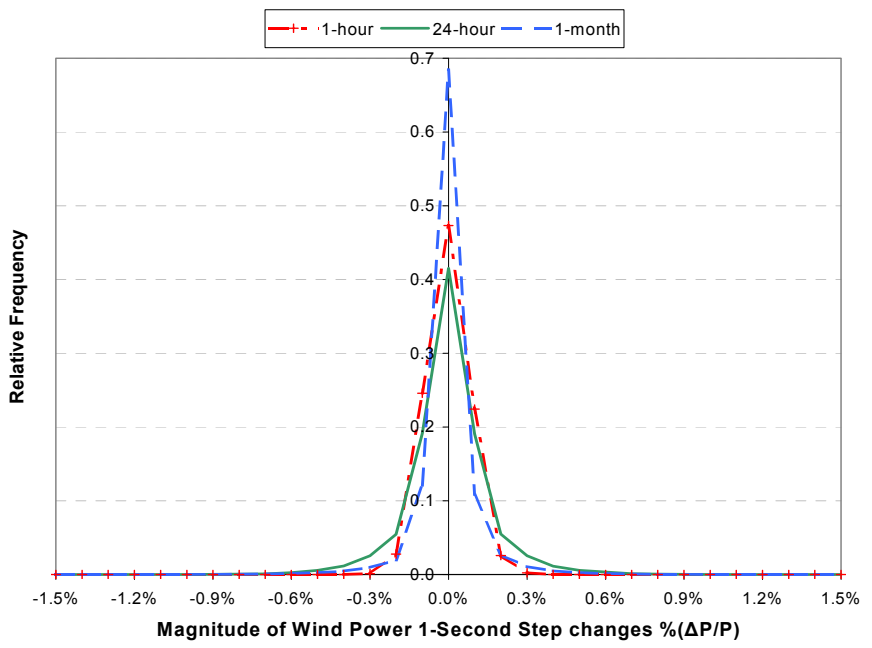

Figure 7. Distribution of 1-second step change values 
Figure 7 clearly shows that the magnitudes of wind power 1-second changes are small. For the 1-hour period in question, all 1-second step changes are within $\pm 300 \mathrm{~kW}$ or $0.3 \%$ of plant capacity. For the month in question, $99.9 \%$ of all 1 -second step changes are within $\pm 800 \mathrm{~kW}$ $(0.8 \%$ of plant capacity) range. For a day, average durations of positive and negative ramping periods are the same 2.3 seconds with the same standard deviation values of 2.7 seconds. For the month, the average of all positive ramping periods is 2.0 seconds (standard deviation 2.0

seconds); the average of all negative ramping periods remains at 2.3 seconds (standard deviation 2.3 seconds). The wind power data show no pattern for second-to-second fluctuations, and there is no reason to believe that one exists. The small second-to-second fluctuations appear to be random.

The appearance of zero differences in the step change distribution plot is the result of the numerical process used for grouping step changes. The chosen width of each bin is $0.1 \%$ of installed capacity, which gives $0.05 \%$ of installed capacity on either side of zero. Very small positive and negative step changes are rounded to zero, thus giving the appearance that wind power does not change. ${ }^{2}$

\subsection{One-Minute Data Series}

There are 10 positive ramping periods (ranging from 1 minute to 6 minutes) and 11 negative ramping periods (ranging from 1 minute to 8 minutes) in the 1 -minute wind power trace of Figure 6. Compared with 16 positive and 16 negative ramping periods of wind speed during the same period, the output power changes less often. The average length of all positive ramping periods is 2.6 minutes and 3.0 minutes for all negative ramping periods. For wind speed during the same period, they are 1.8 minutes and 1.9 minutes, respectively. Power output of a wind plant will remain in one mode (either increasing or decreasing) longer than the wind speed when examined on the same time scale.

The average rate in all 10 positive ramping periods is $0.8 \mathrm{MW} / \mathrm{min}$ and in all 11 negative ramping periods is $-0.7 \mathrm{MW} / \mathrm{min}$; both are smaller in magnitude than the average 1-minute positive and negative step change rates of $0.9 \mathrm{MW} / \mathrm{min}$ and $-0.9 \mathrm{MW} / \mathrm{min}$, respectively. As discussed earlier, the step changes set the outer boundaries of rates of change in a time series. Unless wind power keeps the same rate of change during either a positive or a negative ramping period, the average ramping rates calculated from ramping periods will be less than the 1-minute step change rates.

\footnotetext{
${ }^{2}$ Except when the wind is calm and the output of the wind power plant is zero, the data indicate that a constant power level in consecutive seconds is rare. It is difficult for a large wind power plant with hundreds of turbines scattered over tens of square kilometers, such as the wind power plant near Ruthton, to maintain a constant output for any appreciable time. One factor that may have caused the observed constant power level is the resolution limitations of the instruments used to measure the data. The power transducers at Ruthton wind power plant have a full-scale error of $\pm 0.1 \%$. It stands that on a $100+\mathrm{MW}$ wind power plant, output resolution finer than $100 \mathrm{~kW}$ is not meaningful. Although we have no way to prove it, we suspect that constant outputs in consecutive seconds result from instrument limitations at wind power plants. Constant power level in consecutive minutes occasionally can be observed in the 1-minute average wind power time series. However, further investigation of those very infrequent appearances of unchanging power level reveals that they are the artifacts of rounding in the arithmetic averaging operations. In the hourly power time series, power levels never remain constant from one hour to the next.
} 
For the 24-hour period (Figure 4), wind power peaked at 87.1 MW and dropped to a low of 13.1 MW with an average of $48.7 \mathrm{MW}$ and a standard deviation of $20.8 \mathrm{MW}$. The COV for the wind power is 0.43 , which is about twice the value of wind speed COV of 0.20 . The COV for wind speed during the same period is 0.20 . This result is misleading because available wind power is proportional to the wind speed cubed. Calculated with each wind speed value cubed for this 24hour period, the COV becomes 0.60 , which is a more realistic indication of the variability of available wind power, and as expected, is higher than the COV of wind power plant output.

Calculation of wind power ramping periods provides another way to show the reduced variability of wind power. As shown in Figure 3, there are 431 positive and 430 negative ramping periods in wind speed time series. The power time series contains only 288 positive and 287 negative ramping periods. The average length of ramping periods of the power time series is longer: 2.5 minutes versus 1.7 minutes. The average positive ramping rate is $0.8 \mathrm{MW} / \mathrm{min}$, and the average negative ramping rate is $-0.8 \mathrm{MW} / \mathrm{min}$. The maximum positive ramping rate is $3.5 \mathrm{MW} / \mathrm{min}$, which lasts 3 minutes, and the maximum negative ramping rate is $-3.1 \mathrm{MW} / \mathrm{min}$, which lasts 6 minutes.

There are 1,439 1-minute step differences ( 717 positive steps and 722 negative steps) during this 24-hour period. The largest 1-minute positive power level change is $4.7 \mathrm{MW}$ in 1 minute or about $5 \%$ of the installed capacity. As expected, it is higher than the maximum positive ramping rate. Similarly, the largest 1-minute negative power level change $(-6.2 \mathrm{MW}$ or about $6 \%$ of the installed capacity) is also higher than the maximum negative ramping rate. However, these higher rates of power level changes occur very infrequently and do not sustain. The average of all 1-minute positive power step changes is only at $0.9 \mathrm{MW}$ and at $-0.9 \mathrm{MW}$ for all 1-minute negative power changes.

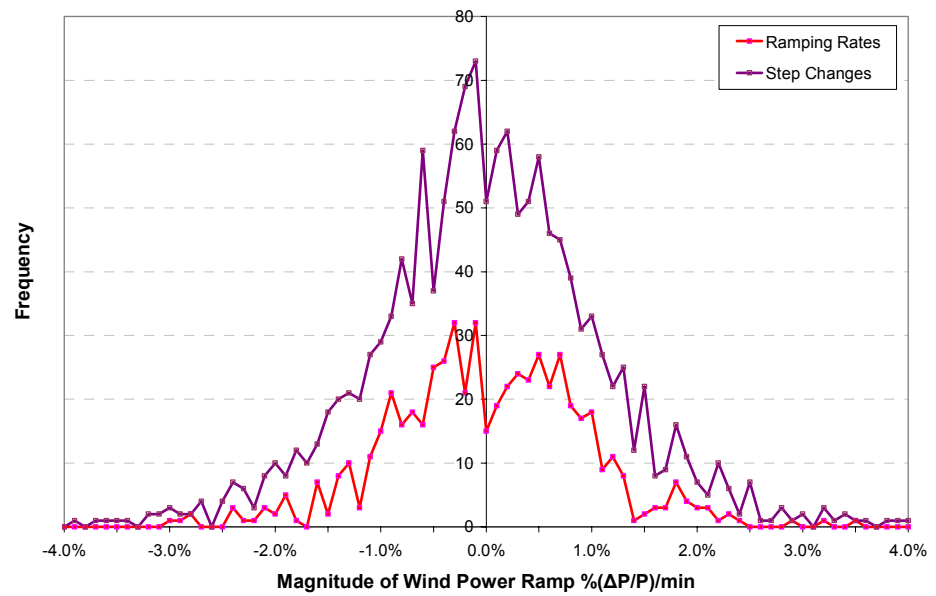

Figure 8. Distribution of ramping rate and step changes values

Figure 8 shows the frequency distribution of positive and negative ramping rates and 1-minute step changes expressed as a percentage of installed capacity per minute. There are only 575 subperiods of monotonically increasing (288) or decreasing (287) power. Both traces in Figure 8 show a small number of zero changes (power level remaining from one minute to the next). As explained earlier, the appearance of zero ramping rate is the result of the numerical process used 
for grouping ramping rates and step changes. There is no actual zero ramping period in the 1minute power time series during this 24-hour period.

Figure 8 shows that most ramping rates and 1-minute step changes are confined between $\pm 3 \%$ of the installed capacity per minute. In fact, $90 \%$ of all ramping rates and $85 \%$ of all 1 -minute step changes are with $\pm 1.5 \%$ of the installed capacity per minute. It suggests that despite the stochastic nature of wind speed and output power fluctuations, the actual short-time changes are relatively small. This point will become even more evident when more data are analyzed.

Table 2 lists monthly statistics of wind speed, COV of wind speed, COV of wind speed cubed, COV of output power, and average values and maximum values of 1-minute power level step changes. The example of using data from a 24-hour period shows that 1-minute step changes are symmetrical about zero, and average values of positive and negative step changes have nearly identical magnitudes. This fact suggests that a single average value of the magnitudes of all step changes can be used to show the variability of power level step changes. The column labeled Average Step Change is the average of absolute step change values (i.e., magnitude only). For the 12-month period, the monthly average 1-minute step changes are less than $1 \%$ of the installed capacity of the wind power plant. Closer examination of the maximum step changes indicates that some of the large step changes were caused by a sudden shutdown of part of the wind power plant. The causes cannot be determined with the data collected. ${ }^{3}$

Table 2. Monthly Statistics of 1-Minute Step Changes

\begin{tabular}{|c|c|c|c|c|c|c|c|c|}
\hline & \multicolumn{2}{|c|}{$\begin{array}{c}\text { Average } \\
\text { Wind Speed }\end{array}$} & \multicolumn{2}{|c|}{ cov } & \multicolumn{2}{|c|}{$\begin{array}{c}\text { Average } \\
\text { Step Change }\end{array}$} & \multicolumn{2}{|c|}{$\begin{array}{c}\text { Maximum Step } \\
\text { Change (MW) }\end{array}$} \\
\hline & $\mathrm{m} / \mathrm{s}$ & cov & Wind Speed ${ }^{3}$ & $\begin{array}{l}\text { Wind } \\
\text { Power }\end{array}$ & (kW) & $\begin{array}{c}\text { (\% of } \\
\text { Capacity) }\end{array}$ & $(+)$ & $(-)$ \\
\hline \begin{tabular}{|l|} 
July 2001 \\
\end{tabular} & 6.20 & 0.45 & 1.34 & 1.13 & 399 & $0.4 \%$ & 16.9 & -7.9 \\
\hline August & 6.37 & 0.39 & 1.06 & 0.96 & 384 & $0.4 \%$ & 22.7 & -19.4 \\
\hline September & 6.77 & 0.42 & 1.04 & 1.01 & 384 & $0.4 \%$ & 7.9 & -5.5 \\
\hline October & 8.48 & 0.41 & 1.17 & 0.74 & 549 & $0.5 \%$ & 7.8 & -6.5 \\
\hline November & 8.26 & 0.45 & 1.14 & 0.67 & 434 & $0.4 \%$ & 14.6 & -12.0 \\
\hline December & 7.86 & 0.41 & 1.19 & 0.68 & 464 & $0.4 \%$ & 12.2 & -8.2 \\
\hline January 2002 & 6.82 & 0.47 & 1.08 & 0.76 & 475 & $0.5 \%$ & 5.6 & -4.8 \\
\hline February & 9.00 & 0.36 & 1.11 & 0.56 & 491 & $0.5 \%$ & 17.4 & -21.4 \\
\hline March & 7.20 & 0.54 & 1.21 & 0.78 & 449 & $0.4 \%$ & 6.6 & -20.0 \\
\hline April & 8.90 & 0.43 & 1.15 & 0.73 & 564 & $0.5 \%$ & 14.7 & -27.6 \\
\hline May & 8.17 & 0.46 & 1.31 & 0.82 & 554 & $0.5 \%$ & 18.0 & -28.5 \\
\hline June & 8.01 & 0.43 & 1.07 & 0.80 & 631 & $0.6 \%$ & 16.2 & -21.7 \\
\hline
\end{tabular}

Table 3 gives the monthly statistics of ramping periods and ramping rates computed with 1minute power data time series. Monthly average ramping rates are similar in magnitude to the monthly average step changes of the corresponding months. The previous example of a 24 -hour

\footnotetext{
${ }^{3}$ Additional step change statistics are listed in tables in the appendices. These statistics are calculated with the recorded data, which contain sudden power drops and rapid power increases caused by forced or maintenance outages and special operations (e.g., curtailment of wind power due to grid constraints). The effects of those relatively small numbers of extreme values on the statistics (average and standard deviation values) should be minimal because of a large number of data points included in the calculation. However, they show up in the columns of maximum values of the tables. No attempt was made to remove these extreme values in the data series.
} 
period 1-minute power series shows that average 1-minute simple step changes expressed in $\mathrm{kW} /$ min have higher magnitudes than that of the average ramping rates. Except for the months of July, August, September, and October, the results in Table 3 follow this convention. Further analysis of those four months reveals the reason the magnitudes of average 1-minute simple step changes are slightly greater than the magnitudes of average ramping rates: the presence of many zero output periods in those months. Zero step changes during the zero output periods lowered the monthly average values of step changes.

Table 3. Monthly Ramping Statistics with 1-Minute Average Power Data

\begin{tabular}{|l|c|c|c|c|c|c|}
\hline & \multicolumn{2}{|c|}{$(\mathbf{+})$ Ramping (kW/min) } & & \multicolumn{2}{l|}{$(-)$ Ramping (kW/min) } & \\
\hline & Average & Maximum & $\begin{array}{c}\text { Average } \\
\text { Time (min) }\end{array}$ & Average & Maximum & $\begin{array}{c}\text { Average Time } \\
\text { (min) }\end{array}$ \\
\hline July 2001 & 446 & 7,233 & 2.9 & -441 & $-4,722$ & 2.9 \\
\hline August & 418 & 8,515 & 2.7 & -415 & $-10,154$ & 2.7 \\
\hline September & 453 & 3,922 & 2.5 & -451 & $-4,480$ & 2.5 \\
\hline October & 553 & 6,072 & 2.6 & -560 & $-6,450$ & 2.6 \\
\hline November & 400 & 8,403 & 2.7 & -402 & $-4,912$ & 2.7 \\
\hline December & 415 & 6,378 & 2.8 & -414 & $-4,925$ & 2.8 \\
\hline January 2002 & 433 & 4,041 & 2.9 & -439 & $-4,400$ & 2.8 \\
\hline February & 460 & 6,952 & 2.5 & -458 & $-8,145$ & 2.5 \\
\hline March & 435 & 5,441 & 2.5 & -444 & $-4,517$ & 2.5 \\
\hline April & 543 & 6,782 & 2.5 & -556 & $-5,300$ & 2.5 \\
\hline May & 535 & 6,698 & 2.6 & -535 & $-5,357$ & 2.6 \\
\hline June & 601 & 7,916 & 2.7 & -609 & $-5,287$ & 2.7 \\
\hline
\end{tabular}

Figure 9 is an example of monthly 1-minute step change and ramping rates distribution. Step changes and ramping rates have similar distribution. The difference in appearance is the result of the differences in numbers of 1-minute step changes and ramping periods in 1 month. As expected, the distribution plot shows that step changes and ramping rates are confined in very narrow ranges. Ninety percent of step changes concentrate in the range of $\pm 1 \%$ of the installed capacity.

The same step change and ramping rate calculations are carried out on the 1-second wind power series of the same 24-hour period. It shows that on average, the output power will change its direction in 2.3 seconds at an average rate of $0.1 \mathrm{MW} / \mathrm{s}$. This and the results of analyses of 1 minute wind speed and output power time series show that fluctuations of wind power are stochastic processes in a short time frame. From one second to the next or one minute to the next, wind speed changes and wind power level changes are random, but these changes are small. 


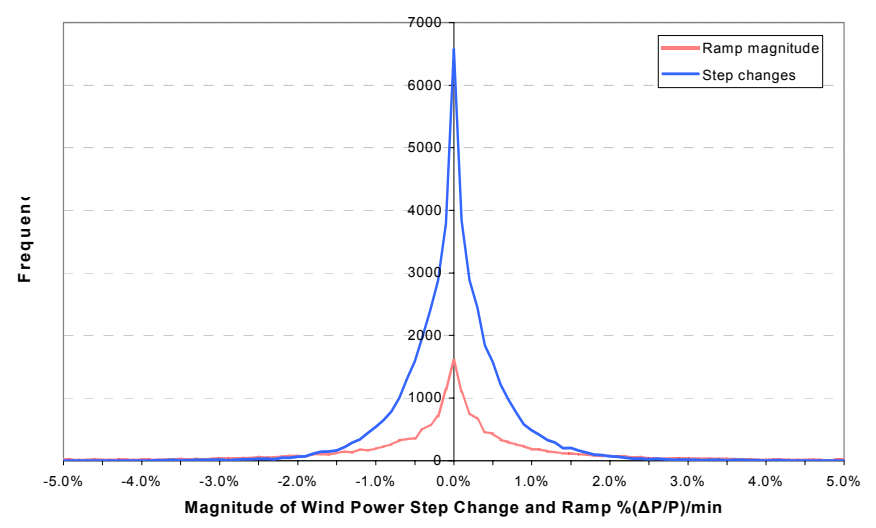

Figure 9. Distribution of monthly step changes and ramping rates

\subsection{Hourly Time Frame Data Series}

The statistics of hourly step changes are also calculated to see the wind power behavior during longer time frames. The wind speed and wind plant output will experience large changes in an hour. Figure 10 is the same 24-hour period wind power series plotted by its hourly average. For the 24-hour period, the wind power averages 48.7 MW. In Figure 10, the largest drop of power in 1 hour is $27 \mathrm{MW}$ ( $26 \%$ of the total capacity), and the largest power increase in 1 hour is 28 MW ( $27 \%$ of the total capacity). The average magnitude of all hourly step changes is $13 \mathrm{MW}$ or $13 \%$ of the wind plant installed capacity. Long-term data show that the maximum values of hourly power change are larger than that of this particular day, but monthly average values are smaller. Table 4 lists the monthly average and maximum positive and negative hourly step change values. Although the average values of hourly step changes are still relatively small ( $5 \%$ to $7 \%$ of installed capacity per hour), the maximum values in Table 4 show that wind power can change significantly in an hour. In the extreme, hourly changes exceed $60 \%$ of the installed capacity.

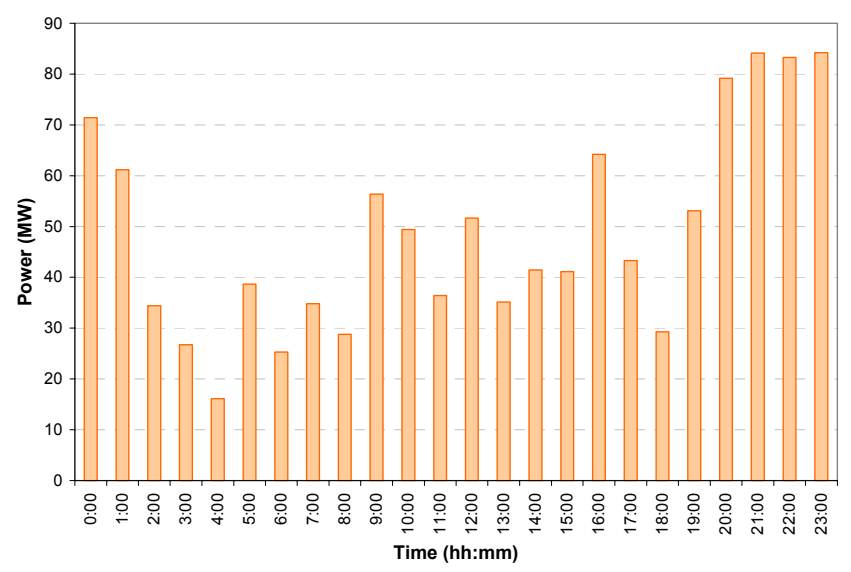

Figure 10. Example hourly power profile of a day

Figure 11 gives the distributions of hourly step changes for 1 month and 1 year. As the figure shows, for both time frames almost all hourly step changes are within $\pm 30 \%$ of the installed 
capacity (about $31 \mathrm{MW}$ in magnitude). For 1 month, 92\% of all hourly step changes are within $\pm 13 \%$ ( $\pm 13 \mathrm{MW})$ of the installed capacity. For the year, $94 \%$ of all hourly step changes are within the range of $\pm 20 \%$ of total capacity (about $\pm 21 \mathrm{MW}$ ).

Table 5 lists monthly average ramping rates and the maximum positive and negative ramping rates computed from the hourly wind power data series. The average ramping values over a 12month period are relatively constant at about $7 \mathrm{MW} / \mathrm{h}$ of $7 \%$ of wind plant capacity per hour. The maximum ramping rates are smaller than their corresponding monthly step changes as expected.

Figure 12 gives the distribution of ramping rates for the 12-month period listed in Table 4 . As Figure 11 demonstrates, $80 \%$ of all wind power ramping has a magnitude of $10 \mathrm{MW} / \mathrm{h}$ or less ( $10 \%$ of the wind plant capacity per hour). Ninety-seven percent of all ramping has a magnitude of $21 \mathrm{MW} / \mathrm{h}$ or less.

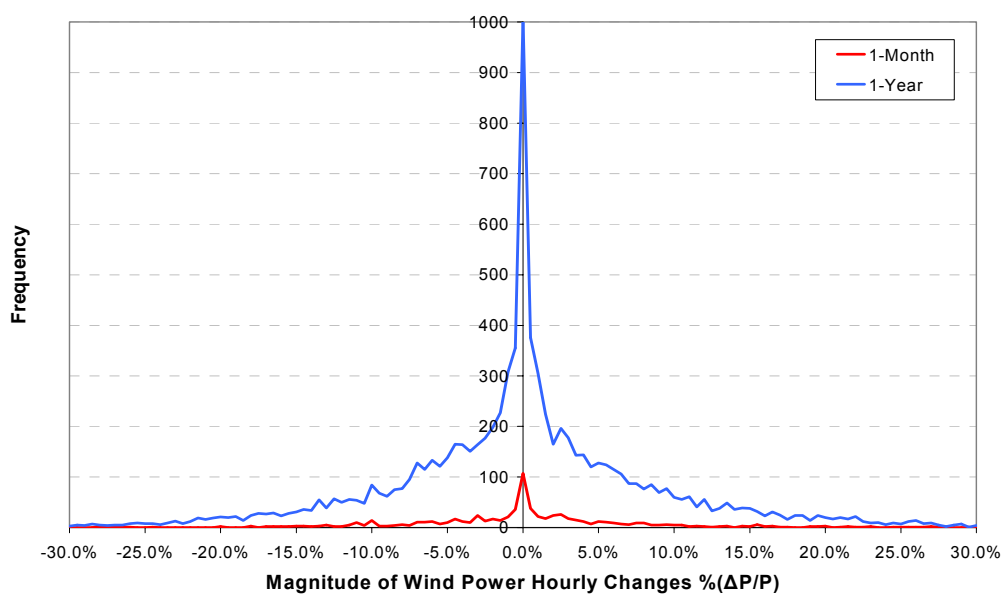

Figure 11. Distribution of hourly step change values

Table 4. Average and Extreme Values of Wind Power Hourly Step Changes

\begin{tabular}{|l|c|c|c|c|}
\hline & Average (MW) & $\begin{array}{c}\text { Average } \\
\text { (\% of Capacity) }\end{array}$ & $\begin{array}{c}\text { Maximum (+) } \\
\text { (MW) }\end{array}$ & $\begin{array}{c}\text { Maximum (-) } \\
\text { (MW) }\end{array}$ \\
\hline July 2001 & 5.6 & $5.4 \%$ & 31.8 & -36.9 \\
\hline August & 5.8 & $5.6 \%$ & 33.0 & -47.5 \\
\hline September & 5.2 & $5.0 \%$ & 32.5 & -68.6 \\
\hline October & 7.2 & $7.0 \%$ & 66.6 & -45.3 \\
\hline November & 6.8 & $6.6 \%$ & 42.5 & -47.9 \\
\hline December & 7.5 & $7.3 \%$ & 49.2 & -39.4 \\
\hline January 2002 & 7.6 & $7.3 \%$ & 40.7 & -38.2 \\
\hline February & 7.2 & $7.0 \%$ & 62.5 & -57.8 \\
\hline March & 6.4 & $6.2 \%$ & 59.4 & -47.8 \\
\hline April & 7.0 & $6.8 \%$ & 58.1 & -48.3 \\
\hline May & 7.3 & $7.1 \%$ & 59.4 & -46.8 \\
\hline June & 7.2 & $7.0 \%$ & 45.0 & -48.8 \\
\hline
\end{tabular}


Table 5. Average and Extreme Ramping Rates with Hourly Wind Power

\begin{tabular}{|l|c|c|c|}
\hline & $\begin{array}{c}\text { Average Ramping } \\
\text { (MW/h) }\end{array}$ & $\begin{array}{c}\text { Maximum (+) } \\
\text { Ramping } \\
\text { (MW/h) }\end{array}$ & $\begin{array}{c}\text { Maximum (-) } \\
\text { Ramping } \\
\text { (MW/h) }\end{array}$ \\
\hline July 2001 & 5.7 & 31.8 & -31.0 \\
\hline August & 5.6 & 33.0 & -36.1 \\
\hline September & 4.8 & 20.0 & -43.4 \\
\hline October & 6.7 & 44.9 & -32.6 \\
\hline November & 6.4 & 38.1 & -36.9 \\
\hline December & 7.2 & 44.4 & -24.0 \\
\hline January 2002 & 7.3 & 25.2 & -29.9 \\
\hline February & 6.6 & 24.6 & -40.3 \\
\hline March & 5.9 & 36.6 & -21.8 \\
\hline April & 7.0 & 46.2 & -35.5 \\
\hline May & 7.4 & 46.0 & -46.8 \\
\hline June & 7.5 & 40.9 & -48.8 \\
\hline
\end{tabular}

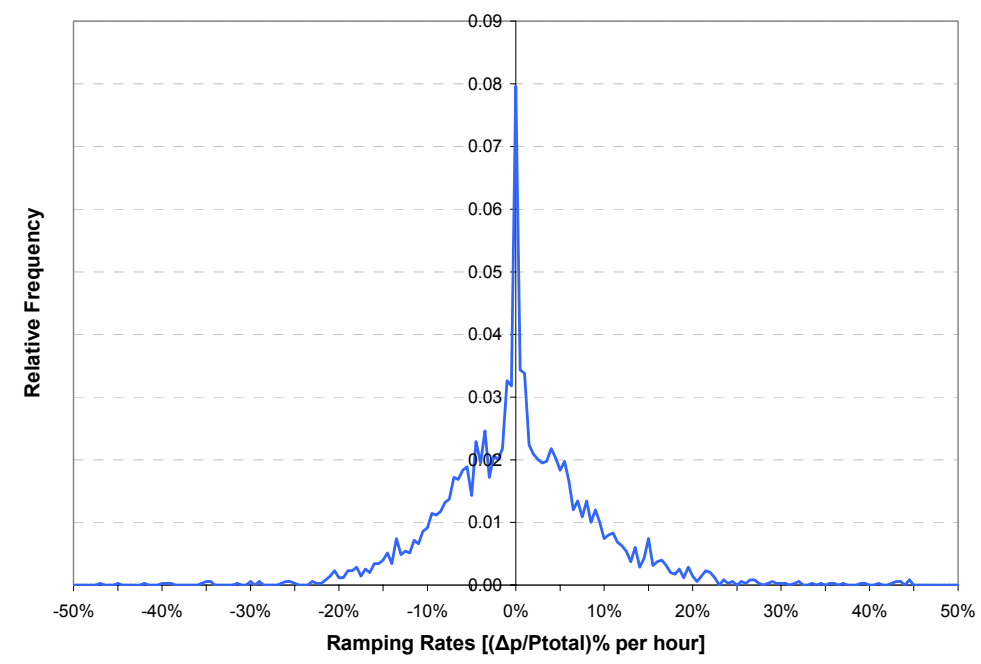

Figure 12. Distribution of hourly ramping rate values

\subsection{Persistence of Wind Power}

The relatively small values of average wind power step changes suggest a strong persistence of wind and the output of a wind power plant. This persistence can also be seen from the state transition rates, which indicate the likelihood of wind power from one level to another level in consecutive time steps. Tables 6, 7, and 8 list the wind power transition rates of the SW Minnesota wind power plant calculated with 1-second, 1-minute, and hourly data series. The row headings indicate power levels in current time step, and the column headings indicate power levels in the next time step. For example, if the current power level is at $40 \%$ of its nameplate power at any particular second (row labeled with 40\%), $99.47 \%$ of the time its output will stay at the same level (column with $40 \%$ heading) at the next second. Its power will jump to $50 \%$ of the rated value next second only $0.27 \%$ of the time, and drop to $30 \%$ of the rated value at the next second $0.26 \%$ of the time. This result is expected with very small average values of 1 -second step changes. 
Table 6. State Transition Rates with 1-Second Power Data

\begin{tabular}{|l|c|c|c|c|c|c|c|c|c|c|}
\hline & $\mathbf{1 0} \%$ & $\mathbf{2 0} \%$ & $\mathbf{3 0} \%$ & $\mathbf{4 0} \%$ & $\mathbf{5 0} \%$ & $\mathbf{6 0} \%$ & $\mathbf{7 0} \%$ & $\mathbf{8 0} \%$ & $\mathbf{9 0} \%$ & $\mathbf{1 0 0} \%$ \\
\hline $\mathbf{1 0} \%$ & 0.9992 & 0.0008 & 0 & 0 & 0 & 0 & 0 & 0 & 0 & 0 \\
\hline $\mathbf{2 0} \%$ & 0.0016 & 0.9967 & 0.0016 & 0 & 0 & 0 & 0 & 0 & 0 & 0 \\
\hline $\mathbf{3 0} \%$ & 0 & 0.0019 & 0.9962 & 0.0019 & 0 & 0 & 0 & 0 & 0 & 0 \\
\hline $\mathbf{4 0 \%}$ & 0 & 0 & 0.0026 & 0.9947 & 0.0027 & 0 & 0 & 0 & 0 & 0 \\
\hline $\mathbf{5 0} \%$ & 0 & 0 & 0 & 0.0034 & 0.9928 & 0.0038 & 0 & 0 & 0 & 0 \\
\hline $\mathbf{6 0} \%$ & 0 & 0 & 0 & 0 & 0.0047 & 0.9893 & 0.0060 & 0 & 0 & 0 \\
\hline $\mathbf{7 0} \%$ & 0 & 0 & 0 & 0 & 0 & 0.0065 & 0.9862 & 0.0074 & 0 & 0 \\
\hline $\mathbf{8 0} \%$ & 0 & 0 & 0 & 0 & 0 & 0 & 0.0084 & 0.9792 & 0.0124 & 0 \\
\hline $\mathbf{9 0} \%$ & 0 & 0 & 0 & 0 & 0 & 0 & 0 & 0.0096 & 0.9762 & 0.0141 \\
\hline $\mathbf{1 0 0} \%$ & 0 & 0 & 0 & 0 & 0 & 0 & 0 & 0 & 0.0102 & 0.9898 \\
\hline
\end{tabular}

State transition rates computed with 1-minute average power data show a slightly different pattern (Table 7). The most prominent feature of Table 7 is that the non-zero values no longer tightly cluster diagonally, which indicates that given more time, much larger power level changes will occur.

Table 7. State Transition Rates with 1-Minute Average Power Data

\begin{tabular}{|l|c|c|c|c|c|c|c|c|c|c|}
\hline & $\mathbf{1 0} \%$ & $\mathbf{2 0} \%$ & $\mathbf{3 0} \%$ & $\mathbf{4 0} \%$ & $\mathbf{5 0} \%$ & $\mathbf{6 0} \%$ & $\mathbf{7 0} \%$ & $\mathbf{8 0} \%$ & $\mathbf{9 0} \%$ & $\mathbf{1 0 0} \%$ \\
\hline $\mathbf{1 0} \%$ & 0.9928 & 0.0072 & 0 & 0 & 0 & 0 & 0 & 0 & 0 & 0 \\
\hline $\mathbf{2 0} \%$ & 0.0140 & 0.9679 & 0.0181 & 0.0000 & 0 & 0 & 0 & 0 & 0 & 0 \\
\hline $\mathbf{3 0} \%$ & 0 & 0.0212 & 0.9560 & 0.0228 & 0 & 0 & 0 & 0 & 0 & 0 \\
\hline $\mathbf{4 0} \%$ & 0 & 0 & 0.0318 & 0.9385 & 0.0296 & 0.0001 & 0 & 0 & 0 & 0 \\
\hline $\mathbf{5 0} \%$ & 0 & 0 & 0 & 0.0374 & 0.9297 & 0.0328 & 0.0001 & 0 & 0 & 0 \\
\hline $\mathbf{6 0} \%$ & 0 & 0 & 0 & 0 & 0.0405 & 0.9187 & 0.0408 & 0 & 0 & 0 \\
\hline $\mathbf{7 0} \%$ & 0 & 0 & 0 & 0 & 0 & 0.0435 & 0.9161 & 0.0403 & 0.0001 & 0 \\
\hline $\mathbf{8 0} \%$ & 0 & 0 & 0 & 0 & 0 & 0.0001 & 0.0459 & 0.9076 & 0.0464 & 0 \\
\hline $\mathbf{9 0} \%$ & 0 & 0 & 0 & 0 & 0 & 0 & 0.0001 & 0.0359 & 0.9376 & 0.0265 \\
\hline $\mathbf{1 0 0} \%$ & 0 & 0 & 0 & 0 & 0 & 0 & 0 & 0 & 0.0191 & 0.9809 \\
\hline
\end{tabular}

The hourly state transition rates are significantly different from 1-second and 1-minute state transition rates. The step change and ramping analyses clearly demonstrate that wind power can experience big changes in hourly time frames, especially when the plant is operating at around $50 \%$ capacity level. At 50\% power level, the power level will remain at 50\% the next hour only $32 \%$ of the time. Some of the outlying values in Table 7 result from forced or planned plant outages, not from dramatic wind speed changes. Also, the total amount of time wind power is at high level (above $80 \%$ of its capacity) is relatively small. Table 8 shows that for this particular plant, if the output level is currently at $90 \%$ of capacity, it may drop to $50 \%$ of capacity (a $40 \%$ drop, or $40 \mathrm{MW}$ for $100 \mathrm{MW}$ plant) the next hour $1.3 \%$ of the time. However, the plant produces $90 \%$ of its capacity less than $9 \%$ of the time during the 12-month period the data are used to calculate Table 8 . Overall, this $40 \%$ drop in 1 hour happened $0.1 \%$ of time (10 times based on 8,760 hourly data points). 
Table 8. State Transition Rates with Hourly Average Power Data

\begin{tabular}{|l|c|c|c|c|c|c|c|c|c|c|}
\hline & $\mathbf{1 0} \%$ & $\mathbf{2 0} \%$ & $\mathbf{3 0} \%$ & $\mathbf{4 0} \%$ & $\mathbf{5 0} \%$ & $\mathbf{6 0} \%$ & $\mathbf{7 0} \%$ & $\mathbf{8 0} \%$ & $\mathbf{9 0} \%$ & $\mathbf{1 0 0} \%$ \\
\hline $\mathbf{1 0 \%}$ & 0.8567 & 0.1199 & 0.0167 & 0.0043 & 0.0019 & 0.0005 & 0 & 0 & 0 & 0 \\
\hline $\mathbf{2 0} \%$ & 0.2196 & 0.4947 & 0.1975 & 0.0697 & 0.0115 & 0.0026 & 0.0018 & 0.0026 & 0 & 0 \\
\hline $\mathbf{3 0} \%$ & 0.0446 & 0.2418 & 0.4252 & 0.2091 & 0.0456 & 0.0228 & 0.0089 & 0.0020 & 0 & 0 \\
\hline $\mathbf{4 0 \%}$ & 0.0051 & 0.0803 & 0.2764 & 0.3439 & 0.1771 & 0.0764 & 0.0306 & 0.0089 & 0.0013 & 0 \\
\hline $\mathbf{5 0} \%$ & 0.0033 & 0.0130 & 0.1317 & 0.2114 & 0.3171 & 0.1805 & 0.0959 & 0.0309 & 0.0130 & 0.0033 \\
\hline $\mathbf{6 0} \%$ & 0 & 0.0089 & 0.0302 & 0.1032 & 0.2402 & 0.3132 & 0.1833 & 0.0890 & 0.0249 & 0.0071 \\
\hline $\mathbf{7 0} \%$ & 0 & 0.0038 & 0.0076 & 0.0440 & 0.1033 & 0.2447 & 0.2849 & 0.2237 & 0.0803 & 0.0076 \\
\hline $\mathbf{8 0} \%$ & 0 & 0 & 0.0073 & 0.0054 & 0.0345 & 0.0726 & 0.2341 & 0.3593 & 0.2523 & 0.0345 \\
\hline $\mathbf{9 0 \%}$ & 0 & 0 & 0 & 0.0026 & 0.0128 & 0.0217 & 0.0562 & 0.1801 & 0.6066 & 0.1201 \\
\hline $\mathbf{1 0 0} \%$ & 0 & 0 & 0 & 0 & 0 & 0.0028 & 0.0028 & 0.0212 & 0.1487 & 0.8244 \\
\hline
\end{tabular}

An obvious use of wind power persistence is wind power forecasting to aid in system operation. Forecasting based on persistence takes advantage of the fact that wind power persists and simply assumes that the current wind power level will persist over the next period. The step change analysis of hourly power data shows that this simple method will produce an average error of about $7 \mathrm{MW}$ with a standard deviation of $8 \mathrm{MW}$ over a 12-month period. Although not good, this is better than entering the next hour with no knowledge of wind power behavior.

\subsection{Daily Wind Power Profile}

The particular hourly power profile in Figure 10 does not resemble an electric system's typical daily load profile. The available data show that the daily wind power profile occasionally has a shape that is similar to an electric system's typical daily load profile. To determine whether daily wind power has a pattern, the average hourly power of a month is calculated to obtain a 24data-point series (from hour 0 to hour 23) for each month. The correlations between the data series of the same months (of different years) are then examined to determine whether any similarities exist. The results suggest that the daily wind power does have distinctive monthly patterns; some months are more prominent than others. For example, Figure 13 plots the wind power hourly profiles for August 2001, 2002, and 2003. There is a diurnal cycle of wind power for the month: The wind power generally peaked at midnight and was at its lowest in early evening. During other months, the patterns are not clearly discernable. However, there are apparently seasonal patterns of hourly power (see Figures 14, 15, 16, and 17). These average daily wind power profiles show that for this particular site, wind power levels are generally higher during the night and early morning hours than those during the day. 


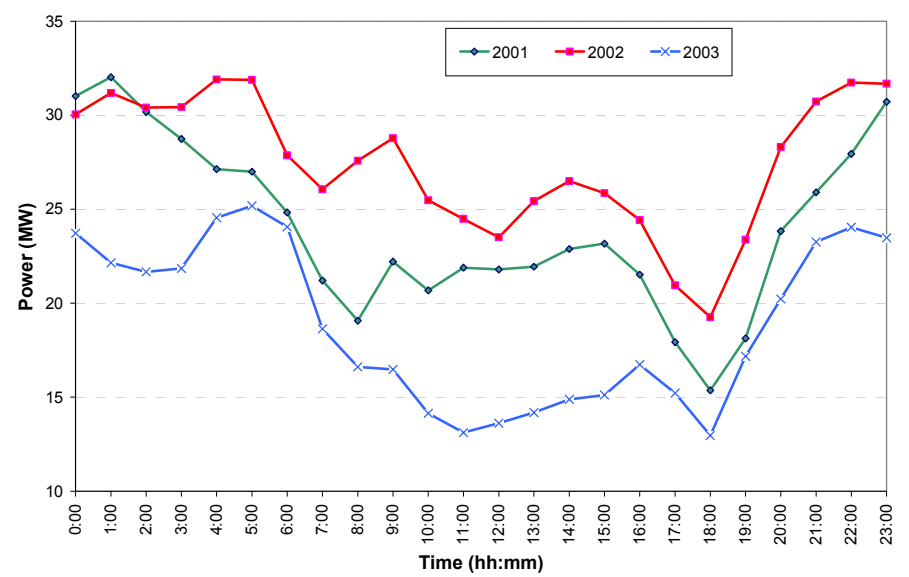

Figure 13. Average hourly power profile for the month of August

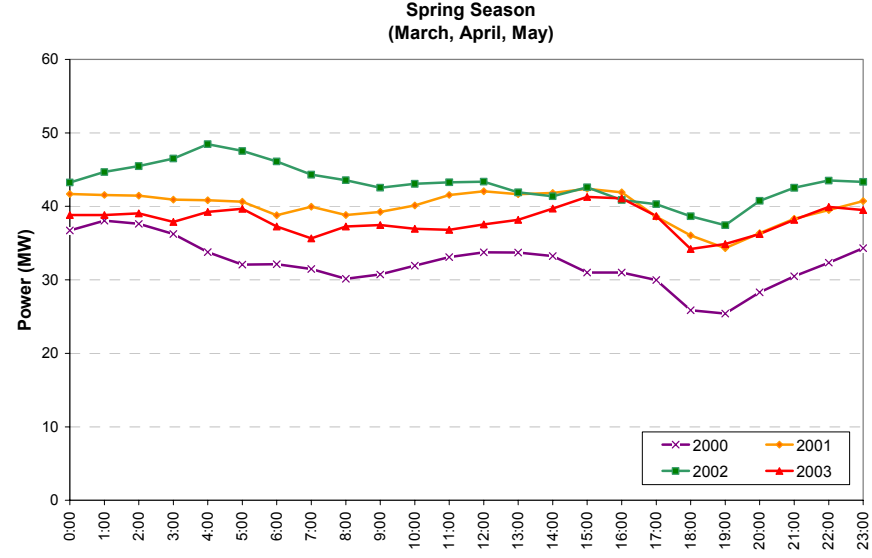

Figure 14. Average hourly power profiles of spring months

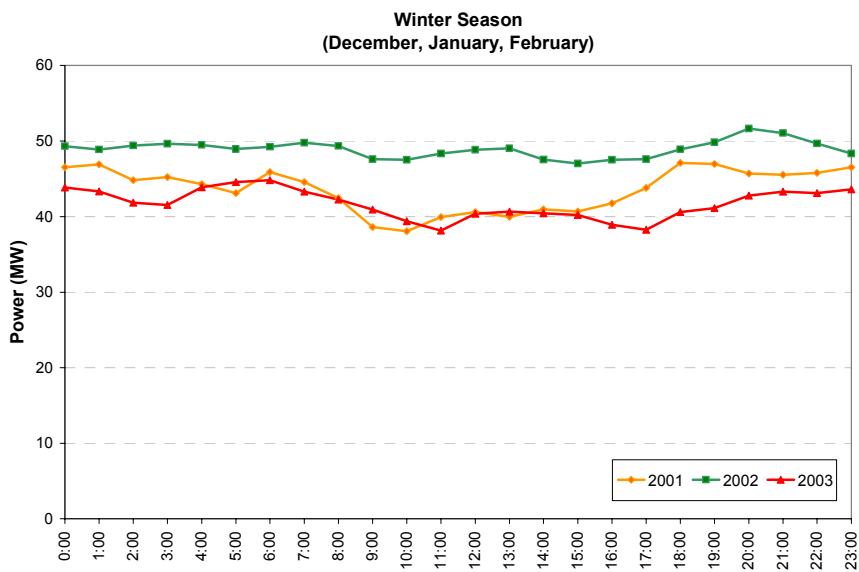

Figure 15. Average hourly power profiles of winter months 


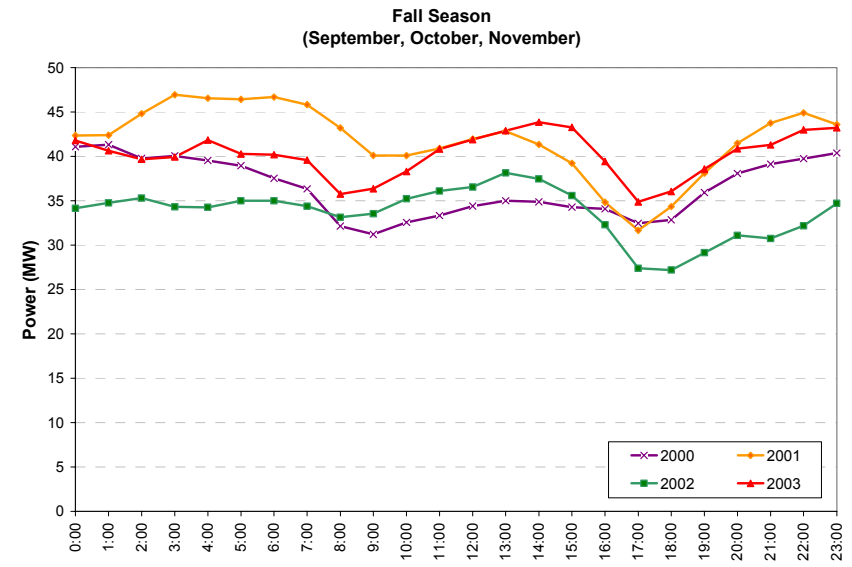

Figure 16. Average hourly power profiles of fall months

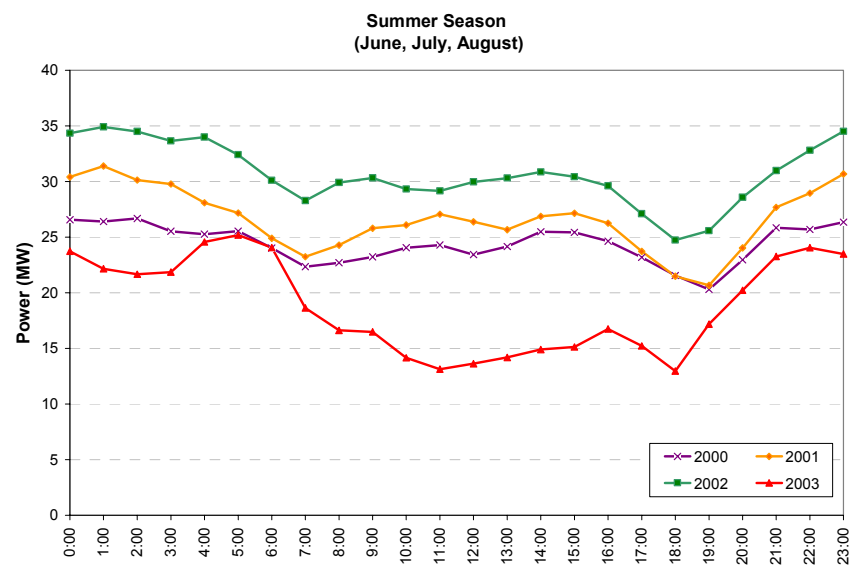

Figure 17. Average hourly power profiles of summer months

It should be emphasized that the monthly and seasonal patterns of the hourly wind power profile shown in Figures 14 through 17 are site specific. Variations in wind energy production are determined primarily by local wind resources, which are affected by local climate conditions. Different sites have different patterns. It can also be seen that significant yearly variations exist. Currently insufficient data exists to establish seasonal patterns of other regions.

\subsection{The Effect of Aggregating Wind Turbines}

Despite their close proximity, instantaneous outputs from individual turbines of a large wind power plant are not synchronized. Physical separations and differences of local terrains cause wind speeds at each turbine to vary. Output power from individual turbines will vary as each turbine is likely operating at different states (e.g., outputs from some turbines increase while others decrease). The diverse outputs from many turbines will make the aggregate output from large numbers of turbines less volatile, especially in short time frames. However, similar wind conditions will eventually sweep over the entire plant. During longer time frames, outputs of individual turbines or groups of turbines should be similar and are likely to move in the same directions. 
The 138 turbines at SW Minnesota wind power plant are installed over an area of approximately $11 \mathrm{~km}$ by $14 \mathrm{~km}$. The turbines are divided into four groups, and four distribution lines are used to feed output power to the utility substation. The numbers of turbines in these four groups are $55,39,30$, and 14. Power data recorded at each line allowed us to examine the effect of large numbers of wind turbines on the power fluctuations.

The differences in short- and long-period wind power correlations can be illustrated with the correlation coefficients among the outputs of these four groups. To show the short-period correlation among the outputs of turbine groups, 1 -second power data are used to calculate the linear correlation coefficients for 15 -second intervals. For long-period correlation, correlation coefficients of 12-hour intervals are calculated with hourly wind power data. The correlation coefficients of 15-minute intervals are also calculated (with 1-minute wind power data) to show the trend of wind power behaviors during the transition period of the intermediate time frame.

The values of correlation coefficients from the 15 -second intervals vary from 0.99 (powers from different turbine groups are almost completely in sync) to -0.99 (powers from different turbine groups move in totally opposite directions) with almost every value in between. The range of 15 -second correlation coefficients suggests that output powers from even nearby wind turbines are not related in short time frames. On the other hand, the correlation coefficients from the 12hour intervals are almost all positive and close to 1 , which indicates that output power from the same turbine groups are highly related in longer time frames. Figure 18 plots the distribution of correlation coefficients from the three chosen time intervals. ${ }^{4}$

Figure 18 shows that the 15 -second interval correlation coefficients are somewhat evenly distributed between -1.0 and 1.0, except for a spike at 0.0 . The high frequencies of zero correlation coefficient values are the results of bin size selected for plotting and zero output in the data stream. This suggests that short-term output power from two nearby groups of turbines can be considered random and independent of each other. If two random variable series are independent, their correlation coefficients have an average value of 0 and a standard deviation value of $0.577(1 / \sqrt{3})$. The average value of the 15 -second interval correlation coefficients is 0.004 with a standard deviation value of 0.606 . Both are very close to the theoretical values. The average value of 15 -minute interval correlation coefficients is 0.108 , which indicates a positive, albeit weak, correlation between output powers from groups of turbines of a large plant in the intermediate time frame. For a longer time frame, the strong positive correlation (i.e., output powers move in sync) is obvious. The average value of the 12 -hour interval correlation coefficients is 0.876 .

\footnotetext{
${ }^{4}$ Total numbers of correlation coefficients are very large. Figure 18 only shows correlation coefficients between the 30 -turbine group and the 55-turbine group. In order for the three correlation coefficients (15-second interval, 15minute interval, and 12-hour interval) to have approximately the same numbers of data points in the plots, the wind power data series used to calculate the three correlation coefficients must be of different lengths. For the 15 -second interval plot, 20 days of 1-second data series are used. For the 15-minute interval plot, 1 month (30 days) of 1minute data series are used. For the 12-hour interval plot, 6 months (184 days) of hourly data series are used.
} 


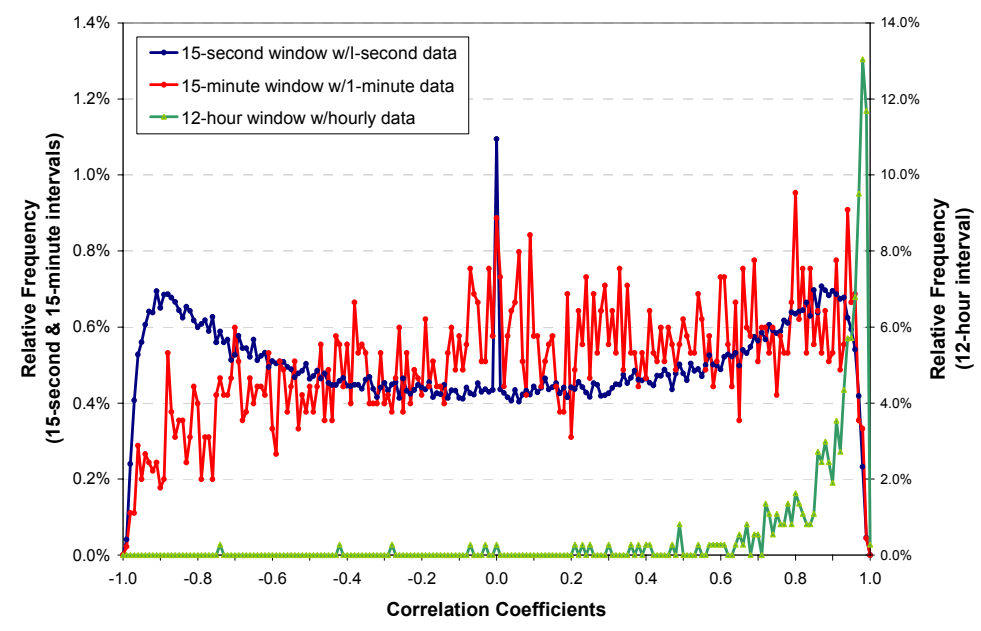

Figure 18. Distribution of correlation coefficients of three time intervals

The effect of aggregation on wind power fluctuations can easily be seen from the statistics of wind power step changes and ramping rates. Table 9 shows average 1-minute step changes of the output powers from the four groups of turbines and the entire wind power plant at the SW Minnesota wind power plant. Table 10 shows the average magnitudes of ramping rates and average lengths of the ramping periods of the 14-turbine group, 39-turbine group, and the entire wind power plant. As the number of turbines increases, the power level changes relative to the total capacity decreases. The wind power ramping rates expressed in terms of total capacity also decrease while the ramping periods become longer with the increasing numbers of wind turbines.

Table 9. Average Magnitudes of 1-Minute Step Changes of Turbine Groups

\begin{tabular}{|c|c|c|c|c|c|c|c|c|c|c|}
\hline & \multicolumn{2}{|c|}{14 Turbines } & \multicolumn{2}{|c|}{30 Turbines } & \multicolumn{2}{|c|}{39 Turbines } & \multicolumn{2}{|c|}{55 Turbines } & \multicolumn{2}{|c|}{ SW Minn. } \\
\hline & (kW) & $\begin{array}{c}(\% \text { of } \\
\text { Capacity) }\end{array}$ & (kW) & $\begin{array}{c}\text { (\% of } \\
\text { Capacity) }\end{array}$ & $(\mathrm{kW})$ & $\begin{array}{c}\text { (\% of } \\
\text { Capacity) }\end{array}$ & $(\mathrm{kW})$ & $\begin{array}{c}(\% \text { of } \\
\text { Capacity) }\end{array}$ & (kW) & $\begin{array}{c}\text { (\% of } \\
\text { Capacity) }\end{array}$ \\
\hline \begin{tabular}{|l|} 
July 2001 \\
\end{tabular} & 106 & $1.0 \%$ & 162 & $0.7 \%$ & 188 & $0.6 \%$ & 227 & $0.6 \%$ & 399 & $0.4 \%$ \\
\hline August & 109 & $1.0 \%$ & 160 & $0.7 \%$ & 186 & $0.6 \%$ & 222 & $0.5 \%$ & 384 & $0.4 \%$ \\
\hline September & 110 & $1.0 \%$ & 170 & $0.8 \%$ & 185 & $0.6 \%$ & 235 & $0.6 \%$ & 384 & $0.4 \%$ \\
\hline October & 146 & $1.4 \%$ & 244 & $1.1 \%$ & 260 & $0.9 \%$ & 313 & $0.8 \%$ & 549 & $0.5 \%$ \\
\hline November & 109 & $1.0 \%$ & 179 & $0.8 \%$ & 202 & $0.7 \%$ & 241 & $0.6 \%$ & 434 & $0.4 \%$ \\
\hline December & 112 & $1.1 \%$ & 189 & $0.8 \%$ & 210 & $0.7 \%$ & 263 & $0.6 \%$ & 464 & $0.5 \%$ \\
\hline \begin{tabular}{|l|} 
January 2002 \\
\end{tabular} & 119 & $1.1 \%$ & 195 & $0.9 \%$ & 217 & $0.7 \%$ & 272 & $0.7 \%$ & 475 & $0.5 \%$ \\
\hline February & 127 & $1.2 \%$ & 209 & $0.9 \%$ & 232 & $0.8 \%$ & 287 & $0.7 \%$ & 491 & $0.5 \%$ \\
\hline March & 123 & $1.2 \%$ & 191 & $0.8 \%$ & 207 & $0.7 \%$ & 258 & $0.6 \%$ & 449 & $0.4 \%$ \\
\hline April & 152 & $1.4 \%$ & 251 & $1.1 \%$ & 263 & $0.9 \%$ & 319 & $0.8 \%$ & 564 & $0.5 \%$ \\
\hline May & 156 & $1.5 \%$ & 247 & $1.1 \%$ & 270 & $0.9 \%$ & 308 & $0.7 \%$ & 554 & $0.5 \%$ \\
\hline June & 162 & $1.5 \%$ & 270 & $1.2 \%$ & 297 & $1.0 \%$ & 356 & $0.9 \%$ & 631 & $0.6 \%$ \\
\hline
\end{tabular}


Table 10. Average Magnitudes of Ramping Rates and Ramping Periods

\begin{tabular}{|l|c|c|c|c|c|c|c|c|c|}
\hline & \multicolumn{3}{|c|}{ 14 Turbines } & \multicolumn{3}{c|}{ 39 Turbines } & \multicolumn{3}{c|}{ SW Minn. } \\
\hline & $\mathbf{( k W / m i n})$ & $\mathbf{( \% / m i n )}$ & $\mathbf{( m i n})$ & $\mathbf{( k W / m i n}$ & $\mathbf{( \% / m i n )}$ & (min) & (kW/min) & (\%/min) & (min) \\
\hline July 2001 & 129 & $1.2 \%$ & 2.7 & 229 & $0.8 \%$ & 3.0 & 443 & $0.4 \%$ & 3.3 \\
\hline August & 126 & $1.2 \%$ & 2.6 & 214 & $0.7 \%$ & 2.8 & 417 & $0.4 \%$ & 3.0 \\
\hline September & 136 & $1.3 \%$ & 2.6 & 234 & $0.8 \%$ & 2.8 & 452 & $0.4 \%$ & 3.0 \\
\hline October & 155 & $1.5 \%$ & 2.2 & 276 & $0.9 \%$ & 2.5 & 556 & $0.5 \%$ & 2.7 \\
\hline November & 113 & $1.1 \%$ & 2.3 & 202 & $0.7 \%$ & 2.5 & 401 & $0.4 \%$ & 2.8 \\
\hline December & 112 & $1.1 \%$ & 2.2 & 199 & $0.7 \%$ & 2.5 & 415 & $0.4 \%$ & 2.9 \\
\hline January 2002 & 129 & $1.2 \%$ & 2.5 & 225 & $0.8 \%$ & 2.8 & 437 & $0.4 \%$ & 3.0 \\
\hline February & 127 & $1.2 \%$ & 2.0 & 228 & $0.8 \%$ & 2.3 & 459 & $0.4 \%$ & 2.5 \\
\hline March & 141 & $1.3 \%$ & 2.4 & 233 & $0.8 \%$ & 2.6 & 440 & $0.4 \%$ & 2.7 \\
\hline April & 159 & $1.5 \%$ & 2.3 & 272 & $0.9 \%$ & 2.5 & 550 & $0.5 \%$ & 2.6 \\
\hline May & 161 & $1.5 \%$ & 2.4 & 280 & $1.0 \%$ & 2.6 & 536 & $0.5 \%$ & 2.8 \\
\hline June & 181 & $1.7 \%$ & 2.6 & 317 & $1.1 \%$ & 2.7 & 606 & $0.6 \%$ & 2.9 \\
\hline
\end{tabular}

Another way to show the effect of turbine aggregation is to scale up the output from a small group to match the output from a large group and compare their step change statistics. Table 11 is an example of such an analysis. In Table 11, the average and standard deviation values under the four turbine groups are calculated with each group's data scaled up so that peak outputs from all groups and the entire SW Minnesota wind power plant are the same. For example, the output from the group of 14 turbines was multiplied by a factor of about $9.7^{5}$ to make it the same as the output of the entire SW Minnesota wind power plant. For the 55-turbine group, the multiplying factor is around 2.4 to scale up its output to the level of the entire plant.

Table 11. Average Magnitudes of 1-Minute Step Changes of Scaled-Up Data

\begin{tabular}{|c|c|c|c|c|c|c|c|c|c|c|}
\hline & \multicolumn{2}{|c|}{14 Turbines } & \multicolumn{2}{|c|}{30 Turbines } & \multicolumn{2}{|c|}{39 Turbines } & \multicolumn{2}{|c|}{55 Turbines } & \multicolumn{2}{|c|}{ SW Minn. } \\
\hline & (kW) & $\begin{array}{c}(\% \text { of } \\
\text { capacity) }\end{array}$ & (kW) & $\begin{array}{c}\text { (\% of } \\
\text { capacity) }\end{array}$ & (kW) & $\begin{array}{c}\text { (\% of } \\
\text { capacity) }\end{array}$ & $(\mathrm{kW})$ & $\begin{array}{c}\text { (\% of } \\
\text { capacity) }\end{array}$ & $(\mathbf{k W})$ & $\begin{array}{c}\text { (\% of } \\
\text { capacity) }\end{array}$ \\
\hline \begin{tabular}{|l|} 
July 2001 \\
\end{tabular} & 1,003 & $1.0 \%$ & 753 & $0.7 \%$ & 643 & $0.6 \%$ & 558 & $0.5 \%$ & 399 & $0.4 \%$ \\
\hline August & 964 & $0.9 \%$ & 708 & $0.7 \%$ & 604 & $0.6 \%$ & 533 & $0.5 \%$ & 384 & $0.4 \%$ \\
\hline September & 1,018 & $1.0 \%$ & 763 & $0.7 \%$ & 645 & $0.6 \%$ & 566 & $0.5 \%$ & 384 & $0.4 \%$ \\
\hline October & 1,416 & $1.4 \%$ & 1,107 & $1.1 \%$ & 918 & $0.9 \%$ & 775 & $0.7 \%$ & 549 & $0.5 \%$ \\
\hline November & 1,049 & $1.0 \%$ & 822 & $0.8 \%$ & 703 & $0.7 \%$ & 599 & $0.6 \%$ & 434 & $0.4 \%$ \\
\hline December & 1,079 & $1.0 \%$ & 853 & $0.8 \%$ & 740 & $0.7 \%$ & 646 & $0.6 \%$ & 464 & $0.5 \%$ \\
\hline \begin{tabular}{|l} 
January 2002 \\
\end{tabular} & 1,141 & $1.1 \%$ & 871 & $0.8 \%$ & 775 & $0.7 \%$ & 666 & $0.6 \%$ & 475 & $0.5 \%$ \\
\hline February & 1,221 & $1.2 \%$ & 929 & $0.9 \%$ & 823 & $0.8 \%$ & 706 & $0.7 \%$ & 491 & $0.5 \%$ \\
\hline March & 1,152 & $1.1 \%$ & 838 & $0.8 \%$ & 766 & $0.7 \%$ & 626 & $0.6 \%$ & 449 & $0.4 \%$ \\
\hline April & 1,424 & $1.4 \%$ & 1,146 & $1.1 \%$ & 973 & $0.9 \%$ & 770 & $0.7 \%$ & 564 & $0.5 \%$ \\
\hline May & 1,421 & $1.4 \%$ & 1,111 & $1.1 \%$ & 977 & $0.9 \%$ & 751 & $0.7 \%$ & 554 & $0.5 \%$ \\
\hline June & 1,468 & $1.4 \%$ & 1,204 & $1.2 \%$ & 1,065 & $1.0 \%$ & 850 & $0.8 \%$ & 631 & $0.6 \%$ \\
\hline
\end{tabular}

Table 11 shows that one cannot simply multiply the output of one turbine or a group of several turbines to find the total output of a plant. The simple scaling operation will exaggerate the fluctuations of wind power and make fluctuation characteristics worse than the actual performance. For example, in July 2001, the scaled-up power from the 14-turbine group had an average 1-minute step change value of $1,003 \mathrm{~kW}$ (or about $1 \%$ of the total plant capacity); the

\footnotetext{
${ }^{5}$ This factor changes with each month as peak outputs are not the same every month.
} 
average 1-minute step change value from the real output of the plant is only $399 \mathrm{~kW}$ (or $0.4 \%$ of the plant capacity) - an increase of $250 \%$. For the 55-turbine group, the average values of 1minute step changes increased $140 \%$ compared to the real output. The output of the group with more turbines already included the aggregation effect, and the scaling effect was less prominent. The relation is close to $\sqrt{n}$, where $n$ is the ratio of total turbines (138 in this case) to the numbers of turbines in the group.

The effect of aggregating more wind turbines can also be seen from a simple statistic: the hourly production. For example, the wind power data of 2003 show that during the 12-month period, the SW Minnesota plant had zero power for 397 hours. For the same period, the Storm Lake outputs were at zero for 834 hours. However, when outputs from both wind power plants were summed up hour by hour, there were only 191 hours and the combined hourly outputs were zero. Furthermore, if the outputs from the Texas wind power plants were added to the combined SW Minnesota and Storm Lake outputs hour by hour, there were only 5 hours during the 12-month period when the wind power was zero. ${ }^{6}$

\subsection{Spatial Diversity of Wind Power}

Large wind power plants that are hundreds of kilometers apart experience significantly more spatial variations of wind resources, and their outputs should be less correlated than those among different turbine groups within a single plant. Their short time frame power fluctuations are independent, and their longer time frame power fluctuations are expected to be less related. This implies that the combined power output of all wind sites under consideration has a lower variability than either site on its own.

Storm Lake is located about $200 \mathrm{~km}$ southeast of the SW Minnesota wind power plant and consists of 151 turbines of the same type as in the SW Minnesota plant. The operations characteristics of individual turbines and the entire plant at Storm Lake are therefore very similar to those of the SW Minnesota wind power plant. The linear correlation coefficients between Storm Lake output and SW Minnesota output are calculated for the same three time intervals (15-second, 15-minute, and 12-hour). Figure 19 plots their distribution.

\footnotetext{
${ }^{6}$ Outputs from Midwest and Texas wind power plants cannot be physically combined because the electric grids that interconnect these faraway plants are not in sync. This calculation is carried out to illustrate the spatial diversity of wind resources.
} 


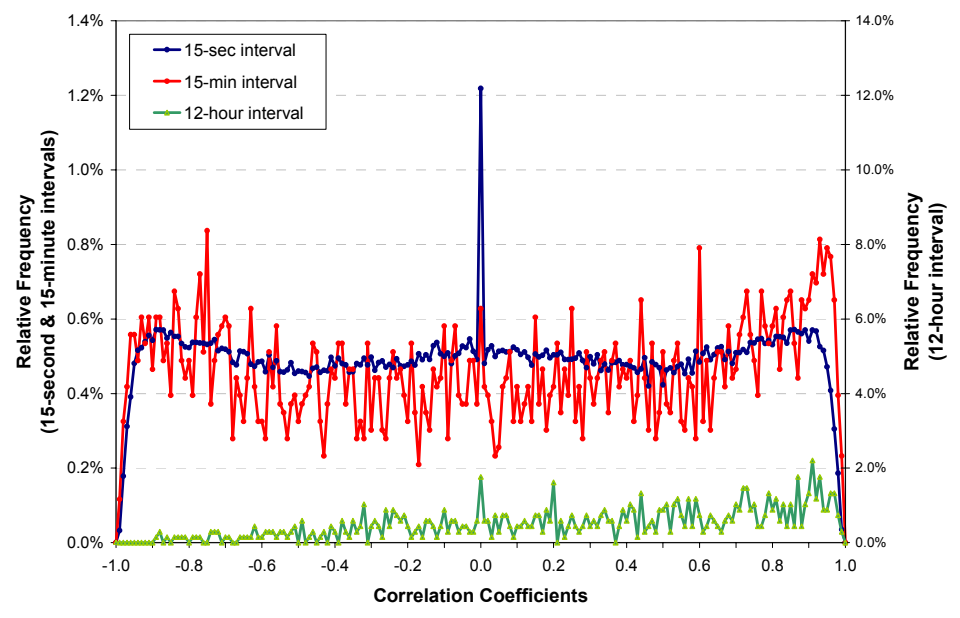

Figure 19. Distribution of correlation coefficients between SW Minn. and Storm Lake

By comparing Figures 19 and 18, the effects of wider physical separation of wind turbines on output power are immediately clear. The distribution of 15-second interval correlation coefficients in Figure 19 is "flatter" than the distribution of 15-second correlation coefficients in Figure 18. Its average value of 0.002 and standard deviation value of 0.573 are "closer" to the theoretical values of a random variable evenly distributed between -1.0 and 1.0 . Unlike the distribution of 15-minute interval correlation coefficients in Figure 18, the distribution of 15minute interval correlation coefficients (the intermediate time frame) in Figure 19 does not show a clear trend toward positive values. The average value of the 15-minute interval correlation coefficients in Figure 19 is only 0.03 . This small value suggests that minute-by-minute outputs from SW Minnesota and Storm Lake are also not related. The distribution of 12-hour interval (longer time frame) correlation coefficients in Figure 19 is significantly different from the 12hour interval correlation coefficient plot in Figure 18. Instead of a predominance of positive values, the plot in Figure 19 shows a trend toward positive values. The average value of the 12hour interval correlation coefficients in Figure 19 is 0.34 . It shows that hourly outputs from SW Minnesota and Storm Lake are weakly correlated despite being $200 \mathrm{~km}$ apart. This is counterintuitive, but a closer examination of the output power time series of these two sites reveals that this is indeed the case. The following section discusses their correlation.

\subsubsection{Output Correlation between Adjacent Wind Power Plants}

Both SW Minnesota and Storm Lake are located in the Buffalo Ridge region. Strong winds here are generally associated with the movements of low-pressure systems that originate from the leeside of the Rocky Mountains to the west and cold arctic air from Canada. The wind direction is mainly north to northwest in all seasons except summer. The plants are about $200 \mathrm{~km}$ apart. The terrain between them is generally flat with little surface roughness. Both plants have similar layouts and the same make of wind turbines. Because of these similarities, and because both sites are often under the influence of the same weather systems, outputs power from the wind power plants at SW Minnesota and Storm Lake over longer time frames, such as hours and days, show a high degree of correlation, especially in the winter. Figure 20, which shows the daily outputs of SW Minnesota and Storm Lake wind power plants, is an example of the high 
correlation during longer time frames between these two plants. During this 120-day period, the correlation coefficient of the daily outputs is 0.77 .

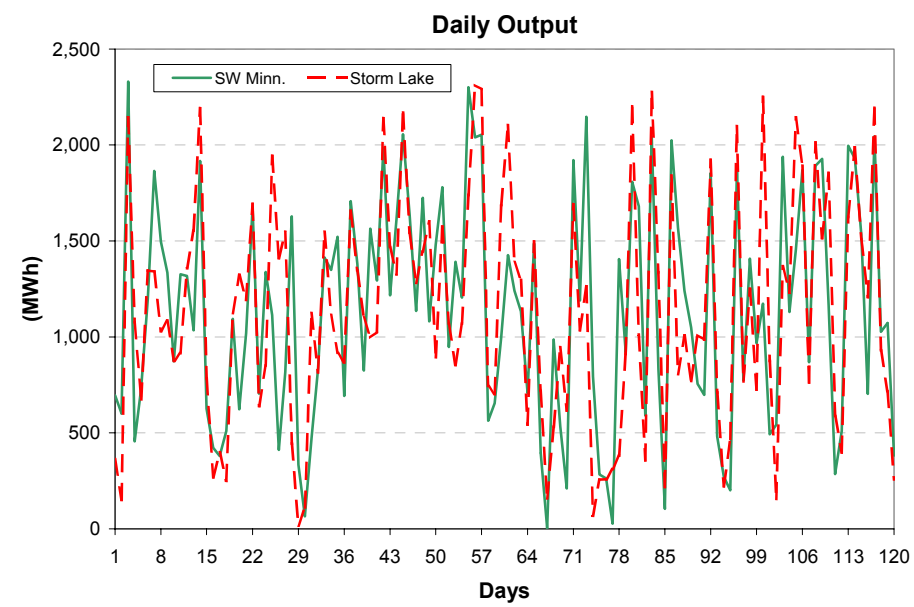

Figure 20. Correlation of daily outputs between SW Minn. and Storm Lake

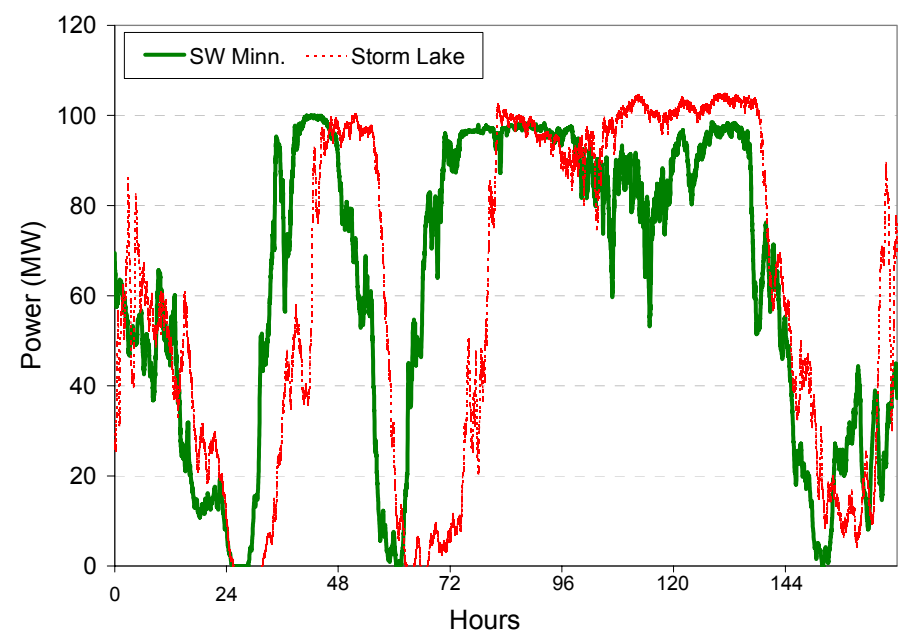

Figure 21. Example of weekly 1-minute average power from SW Minn. and Storm Lake

Figure 21 plots 1-minute average power profiles from both wind power plants for a 7-day period $(168 \mathrm{~h})$. The similarity between the two profiles in Figure 21 clearly shows how Storm Lake outputs are related to SW Minnesota wind power plant outputs during this period. The daily output correlation coefficient for this period is 0.851. The shape of the Storm Lake output profile (red trace) looks like the SW Minnesota plant output profile (green trace) shifted to the right. It suggests a certain temporal relationship between the outputs of these two plants. Calculation of cross-correlation coefficients between SW Minnesota Storm Lake reveals more information about this relationship. 
Figure 22 plots the cross-correlation coefficients between SW Minnesota wind power plant and Storm Lake for the first 96-hour period (from Day 1 to Day 4) in Figure 21. The figure shows the corresponding correlation coefficients when the Storm Lake power signal is shifted from 720 minutes (i.e., delaying the Storm Lake data series 12 hours relative to that of the SW Minnesota) to +1080 minutes (advancing the Storm Lake data series 18 hours relative to the SW Minnesota) in 1-minute increments. The cross-correlation coefficient plot reveals a strong correlation between these two power series when SW Minnesota data are advanced about 6 hours and 40 minutes. This confirms the observation that Storm Lake outputs are indeed similar to those of the SW Minnesota plant at an earlier time.

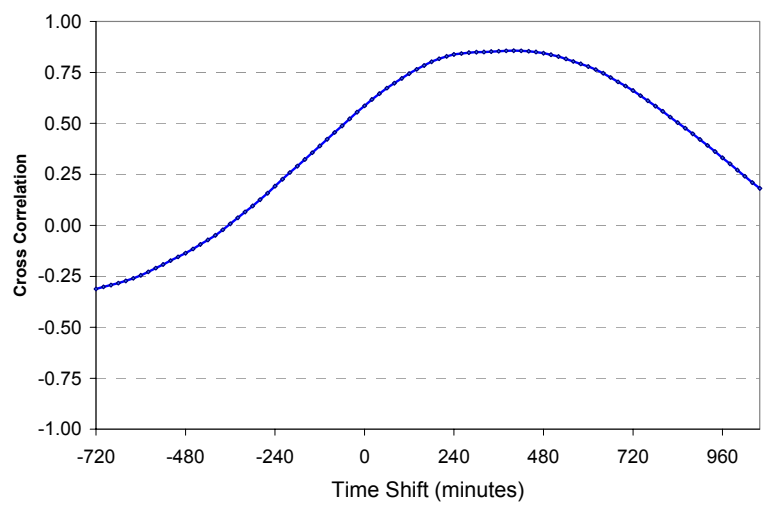

Figure 22. Cross-correlation between SW Minn. and Storm Lake

The example in Figures 21 and 22 shows that well-defined weather systems passed through both plants. The weather systems at SW Minnesota through Storm Lake after a delay that can be estimated from a cross-correlation plot. Because the same types of turbines are installed at SW Minnesota wind power plant and Storm Lake and the plant layouts are similar, the resulting power output profiles from both plants are similar. Meteorologists can predict how fast a weather front travels and when it will reach a certain point. With this knowledge and knowledge of the wind power plant characteristics, the output of the downwind plant can be predicted from the output power of the upwind wind power plant. This phenomenon also explains why longer time frame output powers from these two sites are correlated.

\subsubsection{Output Correlation between Distant Wind Power Plants}

The four wind power plants in Texas are in similar wind regimes, but the distances between them range from $40 \mathrm{~km}$ (between S Upton and SW Upton) to $490 \mathrm{~km}$ (between TWPP in Culberson County and Trent Mesa). Their output correlation is expected to be strongly affected by the differences in distances. Figure 23 plots 1 -minute average power of these plants for a 24 -hour period. It provides some clues on how outputs from the plants correlate. Output profiles of S Upton and SW Upton wind power plants bear some resemblance. The output powers of Trent Mesa and TWPP have much different profiles. This simple observation suggests that during this particular period, outputs from S Upton and SW Upton wind power plants have a higher correlation, but output from Trent Mesa bears little relation to outputs from either S Upton or 
SW Upton. Calculation of correlation coefficients from these three data series confirms it. ${ }^{7}$ The shapes of these profiles indicate that the distance between S Upton and SW Upton is much shorter than that between Trent Mesa and either S Upton or SW Upton. Therefore, S Upton and SW Upton tend to experience similar wind speed patterns. Wind speed patterns at Trent Mesa tend to be different from S Upton or SW Upton because it is farther away. More discussions about output correlations among these plants and between wind power plants in Texas and the Midwest will be presented later.

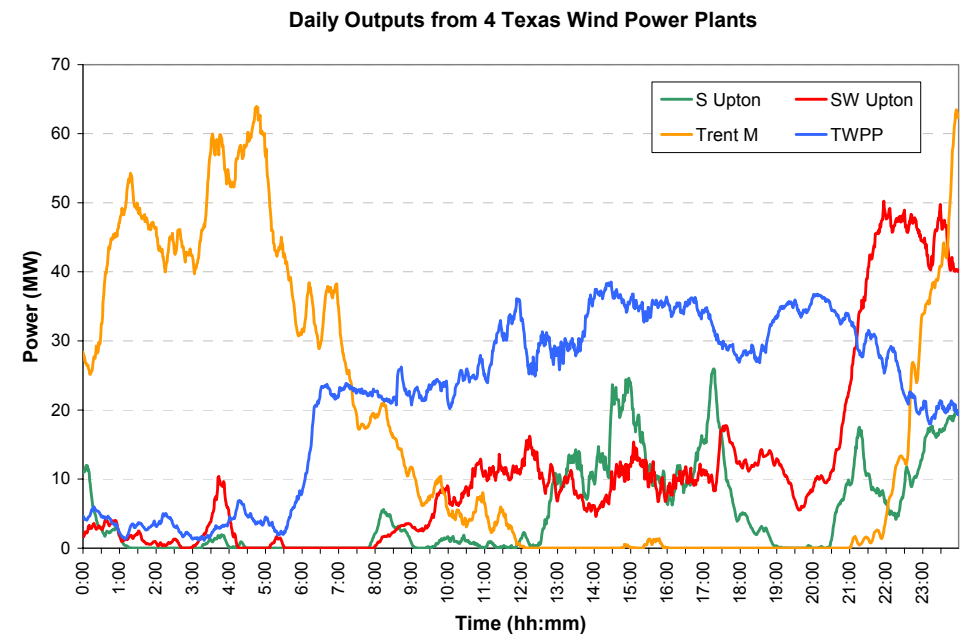

Figure 23. Example daily output profiles of four Texas wind power plants

Despite the differences in wind resources and turbine types, the step changes and ramping rates of Texas plants are similar to those of plants in the Midwest. Table 12 lists the statistics of 1minute step changes expressed as percentages of the total capacity of the respective plants for a 12-month period. Table 13 lists the statistics of 1-minute and hourly ramping rates for the same 12 -month period. The step change values for 1 -minute interval are about $0.4 \%$ to $0.8 \%$ of the total wind plant capacity. All the average hourly step change values are less than $7 \%$ of the plant capacity. The magnitudes of hourly step changes are much larger than that of 1-second and 1minute, but the values of COV become smaller indicating that as the time step increases, the relative changes of power level lessen. Also, as plant capacity increases, the average step changes and their standard deviation values are expressed as percentages of the total capacity decrease.

Table 12. 1-Minute and 1-Hour Step Changes of Texas Wind Power Plants

\begin{tabular}{|l|c|c|c|c|}
\hline & \multicolumn{2}{|c|}{ 1-Minute Step Changes } & \multicolumn{2}{c|}{ Hourly Step Changes } \\
\hline & (\% of Capacity) & COV & (\% of Capacity) & COV \\
\hline S Upton & $0.5 \%$ & 1.72 & $4.8 \%$ & 1.35 \\
\hline SW Upton & $0.8 \%$ & 1.38 & $4.7 \%$ & 1.24 \\
\hline Trent Mesa & $0.5 \%$ & 1.45 & $6.1 \%$ & 1.28 \\
\hline TWPP & $0.8 \%$ & 1.74 & $5.8 \%$ & 1.35 \\
\hline Total Texas & $0.4 \%$ & 1.23 & $4.1 \%$ & 1.06 \\
\hline
\end{tabular}

\footnotetext{
${ }^{7}$ During this 24-hour period, the 1-minute average power correlation coefficient between South Upton and Southwest Upton 0.68 . It is -0.132 between South Upton and Southwest Upton, and -0.005 between Southwest Upton and Trent Mesa.
} 
Table 13. 1-Minute and 1-Hour Ramping Rates of Texas Wind Power Plants

\begin{tabular}{|c|c|c|c|c|c|c|c|c|}
\hline \multicolumn{9}{|c|}{ 1-Minute Power } \\
\hline & \multicolumn{2}{|c|}{ Average (+) } & \multicolumn{2}{|c|}{ Maximum (+) } & \multicolumn{2}{|c|}{ Average (-) } & \multicolumn{2}{|c|}{ Maximum (-) } \\
\hline & $\begin{array}{l}\text { (kW/ } \\
\min )\end{array}$ & $\begin{array}{c}\text { (\% cap/ } \\
\text { min) }\end{array}$ & $\begin{array}{l}\text { (MWI } \\
\text { min) }\end{array}$ & $\begin{array}{c}\text { (\% cap/ } \\
\text { min) }\end{array}$ & $\begin{array}{l}\text { (kW/ } \\
\text { min) }\end{array}$ & $\begin{array}{c}\text { (\% cap/ } \\
\text { min) }\end{array}$ & $\begin{array}{l}\text { (kW/ } \\
\text { min) }\end{array}$ & $\begin{array}{c}\text { (\% capl } \\
\text { min) }\end{array}$ \\
\hline S Upton & 429 & $0.5 \%$ & 12.3 & $14.9 \%$ & -435 & $-0.5 \%$ & -15.3 & $-18.5 \%$ \\
\hline SW Upton & 649 & $0.8 \%$ & 15.4 & $19.5 \%$ & -634 & $-0.8 \%$ & -15.8 & $-19.9 \%$ \\
\hline Trent Mesa & 866 & $0.6 \%$ & 22.4 & $14.9 \%$ & -872 & $-0.6 \%$ & -34.5 & $-23.0 \%$ \\
\hline TWPP & 324 & $0.9 \%$ & 7.8 & $22.4 \%$ & -315 & $-0.9 \%$ & -9.2 & $-26.4 \%$ \\
\hline Total Texas & 1,179 & $0.4 \%$ & 22.1 & $7.1 \%$ & $-1,180$ & $-0.4 \%$ & -44.4 & $-14.3 \%$ \\
\hline \multicolumn{9}{|c|}{ Hourly Power } \\
\hline & \multicolumn{2}{|c|}{ Average (+) } & \multicolumn{2}{|c|}{ Maximum (+) } & \multicolumn{2}{|c|}{ Average (-) } & \multicolumn{2}{|c|}{ Maximum (-) } \\
\hline & $\begin{array}{c}\text { (MWI } \\
\text { h) }\end{array}$ & $\begin{array}{c}(\% \\
\text { cap/h) }\end{array}$ & $\begin{array}{c}\text { (MWI } \\
\text { h) }\end{array}$ & $\begin{array}{c}\text { (\% capl } \\
\text { hr) }\end{array}$ & $\begin{array}{c}\text { (MWI } \\
\text { h) }\end{array}$ & $\begin{array}{c}\text { (\% cap } / \\
\text { h) }\end{array}$ & (MW/h) & $\begin{array}{c}\text { (\% capl } \\
\text { h) }\end{array}$ \\
\hline S Upton & 4.5 & $5.4 \%$ & 46.8 & $56.8 \%$ & -4.2 & $-5.1 \%$ & -28.8 & $-34.9 \%$ \\
\hline SW Upton & 3.8 & $4.7 \%$ & 36.0 & $45.4 \%$ & -3.6 & $-4.8 \%$ & -37.2 & $-46.9 \%$ \\
\hline Trent Mesa & 9.0 & $6.0 \%$ & 73.0 & $48.7 \%$ & -9.0 & $-6.0 \%$ & -82.2 & $-54.8 \%$ \\
\hline TWPP & 2.1 & $6.1 \%$ & 29.5 & $84.2 \%$ & -2.0 & $-5.7 \%$ & -27.8 & $-79.5 \%$ \\
\hline Total Texas & 11.9 & $3.8 \%$ & 83.8 & $26.9 \%$ & -12.0 & $-3.9 \%$ & -96.7 & $-31.0 \%$ \\
\hline
\end{tabular}

The average distance between the plants in the Midwest and Texas is more than $1,450 \mathrm{~km}$. With such a wide separation, their wind resources vary more than those within the same region. The step change statistics of the combined outputs of the Midwest plants and the Texas plants should show even less variability than either group alone. Table 14 shows the results. ${ }^{8}$ The Texas Combined and Midwest Combined columns show the values for the combined outputs of Texas plants and the combined outputs of the SW Minnesota wind power plant and Storm Lake. The Total column shows the values calculated from the sum of outputs of all six plants. The average and standard deviation values of the combined outputs and the COV values decrease.

Table 14. Effect of Aggregating Wind Power

\begin{tabular}{|l|c|c|c|}
\hline & $\begin{array}{c}\text { Midwest } \\
\text { Combined }\end{array}$ & $\begin{array}{c}\text { Texas } \\
\text { Combined }\end{array}$ & Total \\
\hline 1-minute step changes (\% capacity) & $0.3 \%$ & $0.4 \%$ & $0.3 \%$ \\
\hline COV 1-minute step changes & 1.53 & 1.23 & 1.17 \\
\hline 1-hour step changes (\% capacity) & $4.6 \%$ & $4.1 \%$ & $3.4 \%$ \\
\hline COV 1-hour step changes & 1.07 & 1.06 & 0.93 \\
\hline 1-minute data ramping (\%/min) & $0.3 \%$ & $0.4 \%$ & $0.3 \%$ \\
\hline Hourly data ramping (\%/h) & $4.4 \%$ & $3.8 \%$ & $3.2 \%$ \\
\hline
\end{tabular}

Previous analyses have shown that short time wind power series from group of turbines within the same wind power plant are nearly independent. As the time step increases, the wind power series become more dependent. Also, as the distance between plants increases, their output power time series become less related. With such a wide separation, the wind resources at the

\footnotetext{
${ }^{8}$ As previously noted, the electric grids that interconnect these faraway plants are not in sync, and the output of the Midwest plants and the Texas plants cannot be combined. Table 14 shows the relation between aggregation effect and distance.
} 
Midwest and Texas wind power plants are not expected to have a high correlation (even daily). Table 15 shows the monthly average values of correlation coefficients among the four Texas plants. Table 16 shows the average values of wind power correlation coefficients among Texas and Midwest plants. Because previous analyses already show that wind power from groups of turbines within the same plants and from nearby plants are almost independent, only correlation coefficients of 15-minute (calculated from 1-minute power data series) and 12-hour intervals (calculated from hourly power data series) are calculated for Tables 14 and $16 .{ }^{9}$

Table 15. Monthly Average Correlation Coefficients of Powers among Texas Wind Power Plants

\begin{tabular}{|c|c|c|c|c|c|c|}
\hline \multicolumn{7}{|c|}{ Average 15-Minute Correlation Coefficients with 1-Minute Data Series } \\
\hline 2003 & $\begin{array}{l}\text { SW Upton } \\
\text { S Upton }\end{array}$ & $\begin{array}{l}\text { SW Upton } \\
\text { Trent Mesa }\end{array}$ & $\begin{array}{l}\text { SW Upton } \\
\text { TWPP }\end{array}$ & $\begin{array}{l}\text { S Upton } \\
\text { Trent Mesa }\end{array}$ & $\begin{array}{c}\text { S Upton } \\
\text { TWPP }\end{array}$ & $\begin{array}{c}\text { Trent Mesa } \\
\text { TWPP }\end{array}$ \\
\hline January & 0.01 & 0.01 & & 0.00 & & \\
\hline February & 0.02 & 0.02 & & 0.01 & & \\
\hline March & 0.02 & 0.01 & & $(0.01)$ & & \\
\hline April & 0.03 & 0.02 & 0.01 & 0.02 & $(0.00)$ & $(0.00)$ \\
\hline May & 0.02 & 0.01 & 0.01 & 0.01 & 0.00 & 0.00 \\
\hline June & 0.03 & 0.00 & $(0.01)$ & 0.01 & $(0.01)$ & $(0.00)$ \\
\hline July & 0.01 & 0.00 & 0.00 & 0.03 & $(0.00)$ & 0.00 \\
\hline August & 0.01 & $(0.00)$ & $(0.01)$ & $(0.00)$ & 0.00 & $(0.00)$ \\
\hline September & 0.03 & 0.01 & 0.00 & 0.03 & 0.01 & 0.00 \\
\hline October & 0.02 & 0.01 & $(0.02)$ & 0.03 & $(0.00)$ & 0.01 \\
\hline November & 0.02 & 0.01 & 0.02 & 0.02 & 0.00 & 0.01 \\
\hline December & 0.03 & 0.01 & 0.00 & 0.01 & 0.01 & 0.01 \\
\hline Year & 0.02 & 0.01 & 0.00 & 0.01 & 0.00 & 0.00 \\
\hline \multicolumn{7}{|c|}{ Average 12-Hour Correlation Coefficients with Hourly Data Series } \\
\hline January & 0.42 & 0.30 & & 0.29 & & \\
\hline February & 0.48 & 0.17 & & 0.20 & & \\
\hline March & 0.53 & 0.27 & & 0.22 & & \\
\hline April & 0.58 & 0.30 & $(0.04)$ & 0.31 & $(0.09)$ & $(0.05)$ \\
\hline May & 0.33 & 0.29 & 0.05 & 0.16 & 0.08 & $(0.02)$ \\
\hline June & 0.54 & 0.28 & 0.03 & 0.28 & 0.06 & 0.02 \\
\hline July & 0.61 & 0.40 & 0.20 & 0.50 & 0.10 & 0.17 \\
\hline August & 0.61 & 0.35 & 0.08 & 0.47 & 0.13 & 0.06 \\
\hline September & 0.54 & 0.25 & $(0.03)$ & 0.32 & $(0.12)$ & 0.05 \\
\hline October & 0.36 & 0.30 & $(0.01)$ & 0.43 & $(0.01)$ & 0.06 \\
\hline November & 0.37 & 0.30 & 0.03 & 0.12 & $(0.08)$ & $(0.08)$ \\
\hline December & 0.44 & 0.30 & 0.18 & 0.23 & 0.19 & 0.06 \\
\hline Year & 0.49 & 0.29 & 0.06 & 0.30 & 0.02 & 0.03 \\
\hline
\end{tabular}

\footnotetext{
${ }^{9}$ Numbers in Tables 14 and 15 are rounded to the second decimal place. Numbers in parentheses indicate negative values.
} 
Table 16. Monthly Average Correlation Coefficients of Powers from Texas and Midwest Wind Power Plants

\begin{tabular}{|c|c|c|c|c|c|c|c|c|c|}
\hline \multicolumn{10}{|c|}{ Average 15-Minute Correlation Coefficients with 1-Minute Data Series } \\
\hline 2003 & $\begin{array}{c}\text { Storm } \\
\text { Lake/ } \\
\text { SW } \\
\text { Minn. }\end{array}$ & $\begin{array}{c}\text { Storm } \\
\text { Lake/ } \\
\text { Trent } \\
\text { Mesa }\end{array}$ & $\begin{array}{l}\text { Storm } \\
\text { Lake/ } \\
\text { SW } \\
\text { Upton }\end{array}$ & \begin{tabular}{|c|} 
Storm \\
Lake/ \\
S Upton
\end{tabular} & $\begin{array}{l}\text { Storm } \\
\text { Lake/ } \\
\text { TWPP }\end{array}$ & \begin{tabular}{|c|} 
SW \\
Minn.I \\
Trent \\
Mesa
\end{tabular} & $\begin{array}{c}\text { SW } \\
\text { Minn.I } \\
\text { SW } \\
\text { Upton }\end{array}$ & $\begin{array}{c}\text { SW } \\
\text { Minn.l } \\
\text { S Upton }\end{array}$ & $\begin{array}{c}\text { SW } \\
\text { Minn.I } \\
\text { TWPP }\end{array}$ \\
\hline January & 0.01 & $(0.01)$ & 0.01 & 0.01 & & 0.00 & 0.01 & $(0.00)$ & \\
\hline February & 0.03 & $(0.00)$ & $(0.00)$ & 0.01 & & $(0.01)$ & $(0.00)$ & 0.02 & \\
\hline March & 0.04 & $(0.00)$ & $(0.00)$ & 0.02 & & 0.02 & 0.01 & 0.02 & \\
\hline April & 0.03 & 0.01 & 0.00 & 0.01 & $\begin{array}{l}(0.02) \\
\end{array}$ & 0.01 & 0.02 & 0.00 & $(0.02)$ \\
\hline May & 0.02 & 0.01 & 0.01 & 0.00 & 0.00 & 0.01 & $(0.02)$ & 0.01 & $(0.01)$ \\
\hline June & 0.02 & 0.01 & 0.00 & $(0.00)$ & 0.01 & 0.00 & $(0.02)$ & 0.01 & $(0.00)$ \\
\hline \begin{tabular}{|l|} 
July \\
\end{tabular} & 0.02 & 0.01 & 0.01 & $(0.01)$ & 0.01 & $(0.00)$ & 0.01 & 0.00 & 0.02 \\
\hline August & 0.04 & 0.02 & $(0.00)$ & 0.01 & $(0.00)$ & 0.00 & 0.01 & $(0.00)$ & $(0.00)$ \\
\hline September & 0.04 & 0.02 & 0.00 & $(0.00)$ & 0.01 & 0.01 & 0.01 & $(0.01)$ & $(0.01)$ \\
\hline October & 0.01 & $(0.01)$ & 0.00 & 0.01 & 0.01 & $(0.00)$ & 0.00 & 0.00 & 0.01 \\
\hline November & 0.04 & 0.01 & 0.01 & 0.00 & 0.00 & 0.03 & 0.02 & 0.00 & $(0.01)$ \\
\hline December & 0.03 & $(0.00)$ & $(0.02)$ & 0.01 & 0.02 & $(0.01)$ & $(0.00)$ & 0.01 & $(0.01)$ \\
\hline Year & 0.03 & 0.01 & 0.00 & 0.00 & 0.00 & 0.01 & 0.00 & 0.00 & $(0.00)$ \\
\hline \multicolumn{10}{|c|}{ Average 12-Hour Correlation Coefficients with Hourly Data Series } \\
\hline January & 0.29 & 0.05 & $(0.03)$ & $(0.07)$ & & 0.03 & $(0.07)$ & $(0.08)$ & \\
\hline February & 0.24 & $(0.06)$ & 0.02 & 0.04 & & 0.00 & 0.18 & 0.13 & \\
\hline March & 0.31 & 0.09 & 0.17 & 0.35 & & 0.02 & 0.09 & 0.12 & \\
\hline April & 0.42 & 0.11 & 0.12 & 0.11 & 0.06 & 0.11 & 0.07 & 0.12 & 0.07 \\
\hline May & 0.40 & $(0.02)$ & 0.10 & 0.11 & 0.03 & 0.03 & $(0.06)$ & $(0.00)$ & 0.02 \\
\hline June & 0.32 & 0.15 & 0.19 & 0.19 & 0.09 & 0.02 & 0.06 & 0.05 & $(0.06)$ \\
\hline July & 0.20 & 0.20 & 0.08 & 0.08 & 0.18 & 0.11 & 0.03 & 0.09 & 0.07 \\
\hline August & 0.34 & 0.22 & 0.13 & 0.24 & 0.08 & 0.21 & 0.15 & 0.19 & 0.09 \\
\hline September & 0.51 & 0.12 & 0.05 & 0.05 & 0.06 & 0.10 & $(0.02)$ & $(0.06)$ & $(0.02)$ \\
\hline October & 0.39 & 0.09 & 0.07 & 0.02 & $\begin{array}{l}(0.01) \\
\end{array}$ & 0.04 & 0.17 & 0.01 & $(0.00)$ \\
\hline November & 0.24 & 0.11 & 0.10 & 0.02 & 0.07 & 0.21 & 0.05 & 0.03 & $(0.02)$ \\
\hline December & 0.21 & 0.14 & 0.06 & 0.04 & 0.02 & 0.05 & 0.05 & 0.09 & $(0.04)$ \\
\hline Year & 0.33 & 0.11 & 0.09 & 0.09 & 0.07 & 0.08 & 0.06 & 0.06 & 0.01 \\
\hline
\end{tabular}

The second column of Table 16 lists the correlation coefficients of Storm Lake and SW Minnesota wind power plant. The average values of 15 -minute interval correlation coefficients are small, which indicate independence of wind power during short periods. Although the average values of the 12-hour interval correlation coefficients are larger than their counterparts of 15 -minute intervals, their magnitudes are still small (less than 0.1 in all cases). The effect of distances between plants on the correlation of wind power can still be detected from the values in Tables 15 and 16-the farther apart the plants, the less their output powers are related to each other. The outputs from SW Minnesota wind plant and Storm Lake have a high degree of correlation, but they bear little resemblance to the outputs from the Texas plants. Figure 24 is an example of monthly (September 2003) average hourly outputs of these six plants. Because of the differences in plant capacity, the average hourly outputs are normalized in Figure 24 to better illustrate the interrelationships. The six average hourly output profiles confirm the numbers list in Tables 14 and 15. Figure 24 shows that three Texas wind power plants (S Upton, SW Upton, and Trent Mesa) have significantly different hourly profiles from the others. As stated earlier, 
the hourly power profiles are site specific. Long-term data are needed to establish a typical wind power profile for a given location.

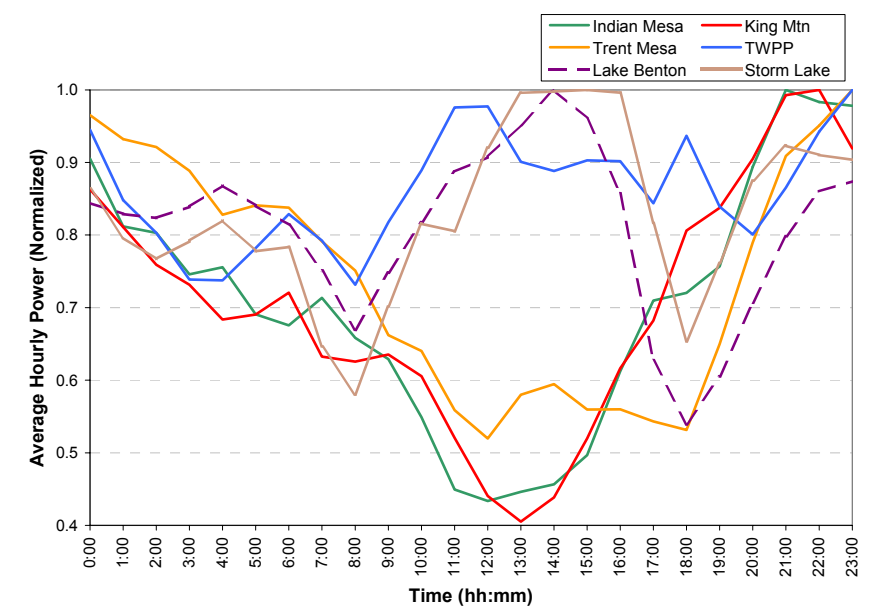

Figure 24. Example of hourly output profiles of Midwest and Texas wind power plants

\subsubsection{Rare Situations}

The analyses of 1-second, 1-minute, and hourly wind power series have established that wind power fluctuations are limited in narrow ranges and their average values are relatively small. With strong winds sweeping across the plant, the output power can increase quickly, as indicated by the maximum values of wind power step changes and ramping rates. However, during such an event, if the ramping up rate needs to be controlled, the plant operators can change the ramping up rate by delaying some of the turbine startups.

Another concern about big wind power change is that power from large wind plants will drop from full capacity to zero very quickly. Grid disturbances or equipment malfunctions can certainly cause the entire wind power plant to trip off line in a very short time. However, other than such forced outage events, wind does not cause the power from large wind power plants to drop instantly. Wind over the entire wind power plant will not change simultaneously. It has been surmised that during certain weather events, the continuously increasing wind speed will be over the turbine cut-off speed at some point and causes all the turbines to shut down after they have been operating at full capacity. Such an event may burden the power system considerably as it tries to bring up generation reserves to compensate for the sudden loss of a large amount of wind power.

In theory this condition is possible; however, data gathered from multiple sites so far have never shown evidence of such an event happening. High wind will exceed wind turbine cut-off speed and cause the turbines to shut down. Power level from those turbines will drop from full capacity to zero quickly (in 1 to 2 seconds). The available data show that the wind power plants as a whole never behave like this. 


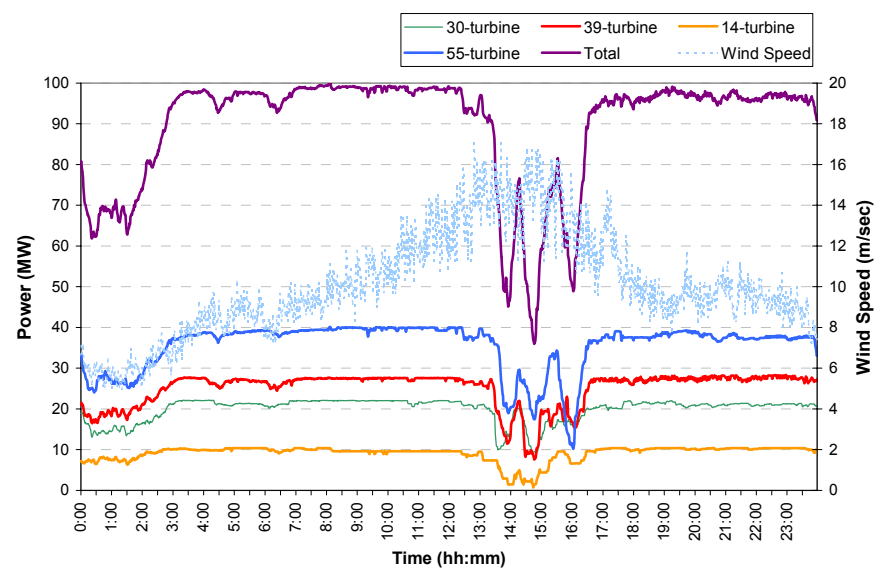

Figure 25. Example of wind power during high wind period

Figure 25 is an example of strong winds that exceeded turbine cut-off speed and caused output to drop. In Figure 25, 1-minute average powers from four turbine groups and the total plant of the SW Minnesota are plotted along with the reference wind speed at the site ${ }^{10}$ for a 24 -hour period. It shows that the plant had been generating at full capacity (about $100 \mathrm{MW}$ ) since 3:00 a.m. with continuously increasing wind. Shortly after 12:00 noon, the output power began to drop, and at about 15:00 when wind speed appeared to be at peak, the output power dropped to the lowest point for the day. After 15:00, wind speed began to decrease, but the output power of the wind plant began to increase (with some fluctuations closely related to the recorded wind speed). At about 17:00, the plant finally generated full power and remained at that level for the rest of the day.

The resolution in Figure 25 does not provide enough information about plant operations during a high wind period. Figure 26 plots 1 -second output power from the four turbine groups during the 3-hour period from 12:00 noon to 15:00. The step changes in the turbine group output traces are about $750 \mathrm{~kW}$ in magnitude (average) and within 2 seconds ( 2 data points). The fact that there are down-steps and up-steps during this period provides further evidence of wind diversities within the plant. These step changes show the shutdown of individual turbines during this high wind period. They also show that all turbines do not shut down at the same instant, although some did appear to occur in rapid succession. The largest 1-second power drop during this 3-hour period was 1.4 MW (two turbines shut down at the same time), but the average ramping was only $293 \mathrm{~kW} / \mathrm{s}$ (less than $0.3 \%$ of total capacity per second). Using 1 -minute power data for this period, the average ramping rate was only $586 \mathrm{~kW} / \mathrm{min}$ with the magnitude of the maximum ramping at $2.2 \mathrm{MW} / \mathrm{min}$. Figure 26 offers clear evidence that output from a large plant does not drop from full power to zero rapidly because of a very strong wind that exceeds turbine cut-off wind speed. Physical separation and local terrain will cause variations in wind speed at individual wind turbines, and therefore all turbines will not be at the same operating status.

\footnotetext{
${ }^{10}$ The wind speeds were recorded by an anemometer mounted on a pole about $4 \mathrm{~m}$ above ground inside a fenced area. Although not hub-height wind speeds, they nevertheless give good indications of the wind conditions at the site.
} 


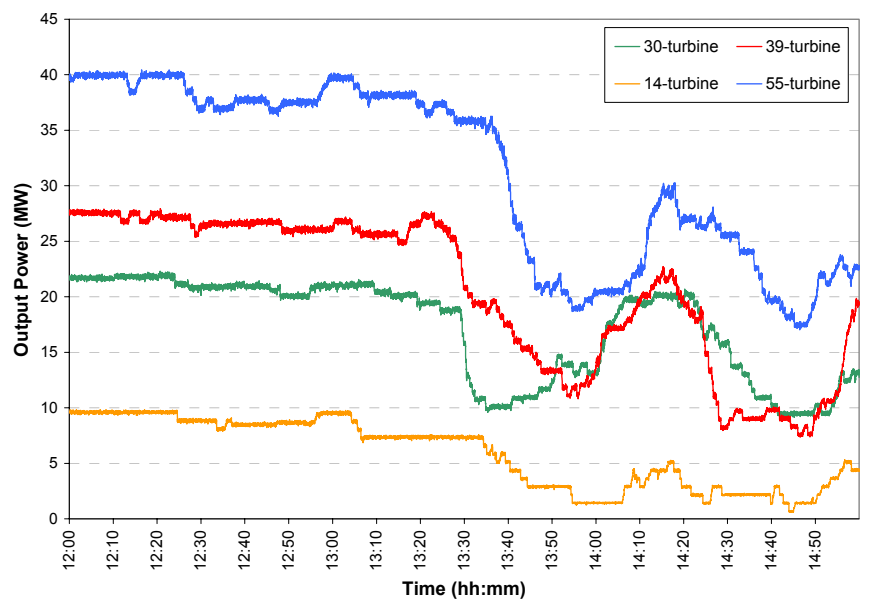

Figure 26. Detail of turbine cut-off with 1-second power data series 


\section{Long-Term Statistics of Wind Power}

Appendices A through $\mathrm{E}$ list additional step change and ramping rate statistics calculated from 1second, 1-minute, 10-minute, and 1-hour wind power data series from the monitored wind power plants in the Midwest and Texas. Appendix A shows the average magnitudes (absolute values) of 1-second step change values, the average values expressed in term of wind power plant capacity, the standard deviation values of step changes, and the monthly maximum positive and negative step change values. Appendix B shows the same statistics calculated with 1-minute wind power data series. Appendix C shows the step change statistics from 10-minute wind power data series. The step change statistics calculated with hourly wind power data series are listed in Appendix D. Appendix E lists statistics of ramping rates from 1-minute wind power data series.

The monthly average 1-second step changes are all very small (ranging from $16 \mathrm{~kW}$ to $259 \mathrm{~kW}$ in value), and the average step change values of large wind power plants are larger than that of small wind power plants. However, when the average step changes are expressed in terms of wind power plant capacity, the differences become much smaller and the relationship between step change value and the wind power plant size also reverses. The 1-second step change values vary from $0.04 \%$ to $0.1 \%$ of the wind power plant capacity. The bigger the wind power plant (or when more wind power is aggregated), the smaller the step changes as a percentage of the total wind power.

The last two columns of the tables in Appendix A list the monthly maximum positive and negative step change values of the monitored wind power plants. Those extreme values are large (especially the maximum negative step changes). The highest wind power level decrease in 1 second is $95 \%$ of the wind power plant capacity — wind plant output from almost full power drops to zero in 1 second. Wind power change of this magnitude apparently is not caused by the wind. It is obvious that such large, instantaneous changes are the result of forced outages of the grid faults or failures of wind power plants. The available data do not reveal the origins of the outages so it is not possible to identify the source of the fault. Figure 27 shows such an example of a large step change of wind power. The red line in Figure 27 is 1-minute average power (leftside scale) of a day, and the dash line shows the corresponding wind speed (right-side scale). 


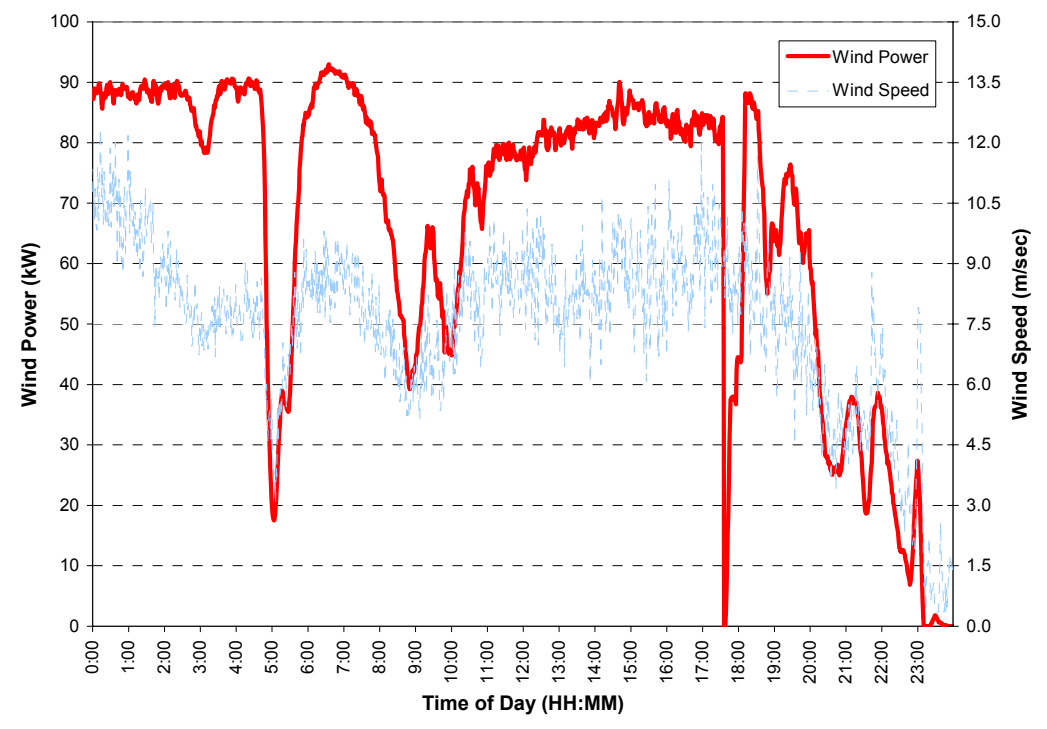

Figure 27. Example of wind power outage

In Figure 27, the wind power generally followed the trend of wind speed. Around 4:40, a large decrease in average wind speed caused the wind power to drop $71 \mathrm{MW}$ (from $89 \mathrm{MW}$ to 18 $\mathrm{MW}$ ) in 23 minutes. This power decrease looks precipitous in Figure 27, but the rate of power decrease was not extraordinary. The largest 1 - second step change was $-530 \mathrm{~kW}(0.5 \%$ of the plant capacity), much less than the maximum negative step change for the month. It is the second large power drop in Figure 27 that is of interest here. The wind power dropped to zero from $84 \mathrm{MW}$ (about $81 \%$ of the plant capacity) in 1 second at around 17:35 and stayed down for about 3 minutes, even though the wind speed did not significantly change during this period. About 3 minutes later, the wind power quickly picked up, but at a much slower rate (1.2 $\mathrm{MW} / \mathrm{second}$ ). Like other such situations in the data stream, the cause of the wind power drop is unclear. In this case, one can rule out the wind turbine fault as the reason for output power drop. It is extremely unlikely that all turbines would fail at the same time, and if it were turbine failure, the wind power plant could not have recovered in such a short time. Although it is likely that momentary grid fault may be the cause, without more information it is not possible to confirm. Nevertheless, the fact that a momentary disturbance of the grid can cause the wind power to drop out of line is also troubling. It implies two critical issues regarding wind power plants.

First, it indicates that the transmission grid connection for the wind power plants is not designed according to the standard practice of power systems. The generally accepted power system planning guidelines call for the system to be designed to withstand any single contingency (first contingency). It appears that some of the large wind power plants currently do not meet this guideline. A single transmission line outage can trip the entire wind power plant off line. Secondly, it implies that the wind turbines do not have the ability to ride through a momentary fault of the transmission grid. This is a design issue of the wind turbines, and turbine manufacturers should be able to solve this issue. Because of the inherent differences between wind power generators (small, induction generators with or without electronic converters) and conventional power generators (large, synchronous generators), it is difficult to require that the wind power plant behave exactly like a conventional power plant. 
Not all large wind power step changes are the results of grid disturbances and wind power plant faults. Some are caused by the failures of monitoring equipments or outages of communication links. Such failures and outages introduce a gap in the data stream and, as a result, large step change values. Discussions with wind power plant operators also revealed that intentional curtailment of wind power plant output is another cause of large wind power changes. Curtailment will occur when the transmission lines around the wind power plant have reached their transfer capacity and cannot accommodate additional wind power. Transfer capacity of transmission lines are determined by conductor thermal limits, voltage limits, and system stability limits, and when any of these limits are reached, system operators issue orders to wind power plants to reduce output. The curtailment of wind power plant output is another indication of the unique situation at wind power plants. As previously noted, conventional power plants are designed to withstand all single contingency conditions, but most of the current wind power plants are not.

For 1-minute data series, the average magnitudes of step changes are between $0.3 \%$ to $1.0 \%$ of the wind power plant capacity, with the small values associated with large wind power plants and vice versa. Tables in Appendix B list step change statistics from 1-minute data series. It should be noted that the standard deviation values of the step change values (a measure of the distribution of step change values around their means) are only slightly bigger than the average values. This confirms that the range of step change values is narrow, as previously discussed. For example, $78 \%$ of the SW Minnesota 1-minute step changes are within the range of $\pm 0.6 \%$ of the plant capacity $( \pm 660 \mathrm{~kW})$ during the 12 -month period included in Appendix A. The extreme 1-minute step change values from a wind power plant are actually smaller than those observed from the 1-second data series of the same wind power plant. It can also be observed that as the wind power plant capacity increases (indicating more turbines in the plant), the extreme step change values expressed as a percentage of the wind plant capacity decreases.

The average 10-minute power level changes are in the range of 0.7 3 MW (Appendix C). Expressed in terms of wind plant capacity, the long-term average 10-minute changes of these six wind power plants are all about $2 \%$ of their respective plant capacity. When the outputs of individual wind power plants are combined, the average magnitudes of step changes of resulting power series become less. The maximum step changes can be large, but these large changes happen infrequently. Most changes are within a narrow range. For example, data from 2003 show that $76 \%$ of the SW Minnesota wind plant 10-minute step changes are within the range of $\pm 2.5 \%$ of its capacity ( $\pm 3 \mathrm{MW}$ or approximately $\pm 1 \sigma$ ), and $91 \%$ of changes are within the range of $\pm 5 \%$ of its capacity $( \pm 2 \sigma)$. The following table shows the distribution of 10 -minute step changes of all six wind power plants. The last column shows the portions of step changes that are greater than $\pm 20 \%$ of the plant capacity. Despite the differences in turbine types and overall wind plant sizes, the step change distributions of these wind power plants are remarkably similar. 
Table 17. Distribution of 10-Minute Wind Power Step Changes as Percentage of Plant Capacity

\begin{tabular}{|l|c|c|c|c|}
\hline \multicolumn{5}{|c|}{ Distribution of 10-minute step changes as percentage of plant capacity } \\
\hline & $<\mathbf{2 . 5 \%}$ & $<\mathbf{\pm 5} \%$ & $<\mathbf{7 . 5} \%$ & $\mathbf{> \mathbf { 2 0 }} \%$ \\
\hline SW Minn. (2002) & $74 \%$ & $90 \%$ & $96 \%$ & $0.2 \%$ \\
\hline SW Minn. (2003) & $76 \%$ & $91 \%$ & $96 \%$ & $0.3 \%$ \\
\hline Storm Lake (2002) & $78 \%$ & $93 \%$ & $97 \%$ & $0.2 \%$ \\
\hline Storm Lake (2003) & $78 \%$ & $93 \%$ & $97 \%$ & $0.3 \%$ \\
\hline S Upton (2003) & $76 \%$ & $90 \%$ & $96 \%$ & $0.4 \%$ \\
\hline SW Upton (2003) & $75 \%$ & $91 \%$ & $97 \%$ & $0.3 \%$ \\
\hline Trent Mesa (2003) & $75 \%$ & $90 \%$ & $96 \%$ & $0.4 \%$ \\
\hline TWPP (2003) & $77 \%$ & $90 \%$ & $95 \%$ & $0.5 \%$ \\
\hline LB \& SL (2002) & $83 \%$ & $96 \%$ & $99 \%$ & $0.08 \%$ \\
\hline LB \& SL (2003) & $84 \%$ & $96 \%$ & $99 \%$ & $0.06 \%$ \\
\hline 4 Texas (2003) & $88 \%$ & $97 \%$ & $99 \%$ & $0.02 \%$ \\
\hline
\end{tabular}

The average magnitude of hourly step changes range from $5 \%$ to $7 \%$ of wind power plant capacity for individual plants (Appendix D). Smaller values are associated with larger wind power plants. For $100 \mathrm{MW}$ wind power, the magnitude of average hourly step changes is around $6 \%$ of the capacity. For $200 \mathrm{MW}$ wind power, the average hourly step changes reduces to about $5 \%$ of the capacity. The average magnitude of hourly step changes further reduces to about $4 \%$ of the capacity for $300 \mathrm{MW}$ wind power. When aggregate wind power reaches $560 \mathrm{MW}$ (outputs Midwest and Texas wind power plants combined), the average magnitude of hourly step changes is about $3 \%$ of the capacity.

The maximum step change values from hourly wind power data series are in the same range of 1 -second and 1-minute extreme step change values, i.e., as high as $80 \%$ of the wind power plant capacity in 1 hour. Closer examination of the wind power hourly step changes reveals that not all of the maximum step change values are the result of wind power plant or grid outages. Some of the maximum step changes are actually caused by the decrease in wind speed from one hour to the next. As expected, the maximum hourly step change expressed in percentage of the total wind power plant capacity decreases when the sizes of wind power plants increase. For example, the maximum hourly step changes at SW Minnesota and Storm Lake are individually about $80 \%$ of the plant capacity, but the maximum hourly step changes of their combined output is only at $48 \%$ of the total capacity. A similar effect of aggregating wind power can also be seen in data from Texas wind power plants. For individual plants, the maximum hourly step changes range from $50 \%$ to $80 \%$ of the plant capacity, and when their outputs are combined, the maximum hourly step change is $36 \%$ of the total capacity.

The average magnitude of wind power ramping is also small (Appendix E). For a small wind power plant of $35 \mathrm{MW}$ capacity, average ramping rate is $0.9 \%$ of capacity per minute (about 310 $\mathrm{kW} / \mathrm{min}$ ). In a larger wind plant with $100 \mathrm{MW}$, the average ramping rate is $0.5 \%$ of capacity per minute $(470 \mathrm{~kW} / \mathrm{min})$. When outputs of more wind power plants are aggregated, the ramping rate in percent of capacity per minute becomes smaller still. The combined SW Minnesota and Storm Lake output has an average ramping rate of about $0.3 \%$ of total capacity per minute $(700$ $\mathrm{kW} / \mathrm{min}$ ). The maximum ramping rates of the monitored wind power plants over a 12-month period can be large. However, closer examination of the data suggests that those large ramping rates are the results of abnormal operations (grid and plant outages and gaps in data stream). 


\section{Planning Considerations}

The analyses of large quantities of high-resolution wind power data series have demonstrated several important aspects of wind power.

1. Although the wind power is stochastic in nature, it is not completely random. It may not be possible to forecast the exact output level of a large wind power plant for any given time, but the persistence of wind power suggests that wind power will not change much from one time step to the next - the shorter the time step, the less the change. Output of a wind power plant follows the changes of wind speed, and wind speed does not change suddenly over a wide area to affect every wind turbine in a large wind power plant at the same time.

2. Wind power fluctuations are concentrated within a narrow range. This is a corollary to the wind power persistence in item 1 above. The average values of second-by-second changes of wind power are less than $0.1 \%$ of plant capacity. Maximum 1-second changes in power level are about $1 \%$ of plant capacity and occur infrequently. The average 1 -minute step changes of wind power are only about $0.3 \% \sim 1.0 \%$ of plant capacity. Higher values are for smaller plants and lower values are for larger plants. Compared to the natural fluctuations of system loads, these short-term fluctuations are too small to have any impact on system operations. The largest 1-minute power level changes can reach $70 \%$ of plant capacity, but those extreme values appear to be caused by outages of the plant or the grid.

The short-term wind power data also highlight a unique attribute of a wind power plant. Unlike other types of large power plants, which can lose all of their generation capacity because of internal faults, the malfunction of a single turbine will not cause all turbines in a wind power plant to trip off line at once. Thus, the reliability of a wind power plant is actually higher than that of a large conventional power plant. The system can lose all the generation of a wind power plant when the line connecting to it trips because of a fault.

For 10-minute intervals, the average magnitudes of wind power step changes vary around $2 \%$ of the wind power plant capacity. For a 100-MW wind power plant, the average absolute values of 10-minute power level changes are around $2 \mathrm{MW}$. This value is smaller than the average magnitude of load forecasting errors expressed in terms of total system load. ${ }^{11}$ The data show that sizes of the plants and turbine types have little effect on 10-minute step change statistics. The 10-minute interval maximum power level changes are only slightly bigger than the corresponding values of the 1-minute interval.

Wind power can change substantially in the hourly time frame. The average magnitudes of hourly step changes are still relatively small, ranging from $4.5 \%$ to $6.4 \%$ of wind plant capacity. These percentage values are calculated with the nameplate capacity of the respective plants. The differences in the average hourly step changes magnitudes, expressed as a percentage of plant capacity, will be smaller if the actually achieved maximum power output is used to calculate the percentage values. It shows that the operations of wind power plants in different regions and with different types of turbines are very similar. The output power variations are a function of short-term wind speed variations, which is similar

\footnotetext{
${ }^{11}$ Hirst, E. "Integrating Wind Energy With the BPA Power System: Preliminary Study," September 2002.
} 
everywhere. Large plants (with more turbines) tend to fluctuate less (relative to total installed capacity) in their outputs and vice versa. It appears that output fluctuations of a wind power plants are determined more by the size of the plant. The types of turbines and locations of the plants have less influence.

3. The maximum magnitudes of hourly wind power level changes can be significant. With favorable wind, a plant can start up and reach its full output in an hour and shut down just as quickly. The largest monthly maximum hourly step changes list in the Appendices is about $80 \%$ of plant capacity. Those large step changes were caused by outages outside the plants. Excluding the grid-outage-induced large step changes, the largest power level change of a plant was about $70 \%$ of plant capacity in an hour during a 12-month period. These changes occur infrequently. The step changes statistics show that even with the outages, wind power plants do not drop from full capacity to zero in an hour or less. The rate of power increase can be modified with a proper control strategy that limits the number of turbines that are allowed to start simultaneously. The rapid decrease of wind power is difficult to remedy. Better wind forecasting can help mitigate the impact on system operation.

4. Wind power profiles are location specific. The data show different regions have different daily, monthly, and seasonal wind power profiles. Wind power data from one region can be used to predict fluctuation behavior from second-to-second up to hourly, but they are not good indicators of daily and monthly performance of plants in other regions. The utility system load follows predictable daily, weekly (weekdays and weekends), and seasonal (summer cooling, winter heating, on-peak, off-peak) patterns. With long-term wind power data, seasonal average output profiles can be assembled for the region, but they may not be applicable to other regions. In addition, the available data do not show that wind power has any distinctive weekday and weekend profiles.

Utility planners usually compile some representative load profiles for system analysis and planning. With wind power, a different approach may be necessary because its stochastic nature makes compiling representative daily or seasonal profiles for a specific region difficult. The critical issue is that the wind power profiles capture the characteristic wind power variations.

Long-term wind power data from several locations are available from the NREL wind farm monitoring project. The data can be made available to utilities for impact analysis and planning. These actual wind power data are better than any power series synthesized from measured or assumed statistical property of wind power.

5. Multiplying the output of single or small numbers of turbines to emulate the expected output (either energy or power) of a large plant does not provide realistic results. The output from a large plant with many turbines will fluctuate less than that from a single turbine or a small group of turbines. The spatial and temporal variations of wind speed within a large plant make the combined output less variable. The effect of simple scaling up is equivalent to force all turbines in a large plant to operate in sync and exaggerate the fluctuations of the output power. The data prove that such a practice, sometimes performed because of lack of data, is not advisable. Also, one cannot simply extrapolate the data from a single 
anemometer to plant output because the resulting plant output will have much worse fluctuation characteristics. This issue has great impact on the planning and integrating of wind power into the grid. Much research has been done in this area and more will be needed to find a solution to this problem.

6. Capacity value or capacity credit of a generating plant to a utility power system is a very important measure in system planning and operation. There are different ways to assess the capacity credit of a power plant. For planning purposes, it is typically calculated with a reliability model that simulates the electricity production under various conditions. In operations, actual output from a power plant during system peak load periods is sometimes used to represent the capacity credit. Long-term statistics of power plant output, especially hydro units, often form the bases for such methods. Regardless of which methods are used to assess the capacity credit of power plants, the results depend on the individual system characteristics, such as load profiles, generation mix, and maintenance practice.

Wind plant capacity credit can be calculated with a standard utility method. Researchers at NREL and other institutes have studied this issue. Their results show that despite the variable nature of wind, wind power can enhance system reliability and thus has capacity value. However, wind power capacity credit is more site specific than conventional generating technologies. In addition to system attributes (load, generation mix, and other operating practices), capacity credit of wind power also depends on wind resources specific to the location of the plant. Using wind resource data or wind power data from other locations to assess wind power capacity credit introduces high uncertainty.

7. Unlike conventional power plants, many present wind power plants do not appear to be able to withstand single contingencies of the grid. A large wind power plant is more reliable than a conventional fossil-fueled power plant of similar size because it is extremely unlikely that all turbines will fail at the same time. Despite this fact, the availability of wind power plants is often negatively impacted by single line outage. Many factors contribute to this situation and a discussion is beyond the scope of this report.

An issue being raised recently is the ride-through capability of wind turbines. When wind power is only a tiny fraction of the system capacity, its operating status generally is of no consequence to the system operation. To avoid complicating the system restoration procedure, utilities usually require the wind power plant to be offline when a disturbance occurs in the system. The wind power plant will remain offline until the disturbance is cleared and the normal system state is reached. Wind turbine manufacturers and wind power plant operators adopt this practice to protect wind turbines from being damaged by the system disturbance. With increasing wind power penetration, utilities begin to take a different approach to this issue. Because of the inherent differences between wind power plants and conventional power plants, it is difficult to require a wind turbine to behave exactly like a synchronous generator. For a large wind power plant consisting of many wind turbines, the behavior of each individual turbine is of little consequence to the utility grid operation, but the performance of the wind power plant is of higher importance. 
To facilitate the integration of a large amount of wind power into the electric system, the American Wind Energy Association (AWEA) filed recommendations with the Federal Energy Regulatory Commission (FERC) regarding the treatment of wind generating plants under FERC's rulemaking (Order 2003 A, which established national standards for interconnection of new generators to the interstate electric grid). ${ }^{12}$ Based on industry group consensus, AWEA's recommendations include wind turbine and wind power plant lowvoltage ride through capabilities, reactive power and voltage support criteria for the wind power plant, and communication and control standards for wind power plants to allow for remote control. In addition, AWEA's filing also recommended formal processes for the involved parties to develop and update engineering models of wind power plants for interconnection analysis.

AWEA filing represents the first step the industry has taken for a balanced approach to the issue. The requirements for wind power plants may change as the wind power technology continues to improve.

8. Impact from wind power to a system cannot be quantified without a detailed analysis. The power system response to the wind power changes is a critical issue. Several utilities have initiated studies to examine this issue. Some of the studies are in progress. Links to some of the reports are given in Appendix F. Generally accepted models are available for utilities to simulate the system operations with conventional power plants and plan future expansion to meet the expected load. Models can accurately simulate the wind power plant operation, and their impacts on the system operations are still being developed. One of the difficulties facing industry members trying to answer this question is lack of information. NREL wind power data only show the behavior of wind power plants, but the corresponding system data such as load, generation, and utility area control error (ACE) are not available. For a complete understanding of the interactions between wind power and the rest of the system, it is imperative to have both wind power data and system data.

\footnotetext{
${ }^{12}$ FERC Docket No. RM02-1-005, Petition for ruling making or, in the alternative, request for clarification of Order
} 2003-A, and request for technical conference of the American Wind Energy Association. May 20, 2004. 


\section{Summary and Conclusions}

It is clear that for normal operation, the short-term fluctuations of a wind power plant are very small: about $0.1 \%$ of plant capacity for 1 -second data series, less than $1 \%$ for 1 -minute data series, and from $3 \%$ to $7 \%$ for hourly data series. For a $100 \mathrm{MW}$ wind power plant the average minute-by-minute power level change is only about $1 \mathrm{MW}$. Average ramping rates range from $1 \% / \mathrm{min}$ for a wind plant of $35 \mathrm{MW}(350 \mathrm{~kW} / \mathrm{min})$ to $0.2 \% / \mathrm{min}$ for aggregate wind power of 560 MW (1.4 MW/min). For most systems, these small variations are well within the range of normal system load variations. The addition of wind power may or may not appreciably increase system regulation duties, depending on the correlation between the wind fluctuations and load fluctuations. The distribution of hourly step change values is wider than that from the short-term data series. The maximum hourly step change values can be large (up to $80 \%$ of plant capacity in an hour). However, the data show that such large step changes occur infrequently. Furthermore, weak transmission lines interconnecting wind power plants to the power system are responsible for the large wind power changes experienced by the power system.

The data also suggest that output fluctuations are influenced mainly by the size of the wind power plants. Differences in turbine types and plant locations play much lesser roles in determining the step changes of wind power. For two wind power plants of the same installed capacity, the statistics of their step changes will be very similar.

When more wind power plants are connected to the system, the diverse wind resources of various locations will make the aggregate output less volatile. The statistics of power fluctuations (step changes and ramping rates), when expressed in terms of total wind power capacity, will be smaller than those of an individual wind power plant. However, the actual magnitudes of step changes in MW or kW will be larger than those of an individual wind power plant. In this situation, the system control areas will face higher regulation duty. Although the probability of calm wind at every wind power plant becomes smaller and smaller as more plants are scattered over wider areas, such an event is still possible. The maximum step changes will also be higher in magnitude. Studies are underway to examine and quantify the impacts of conditions. Better wind forecasting can alleviate the impacts.

A corollary to the observed wind power temporal and spatial diversity is the cautionary note on the attempts to simply scale up or down wind power from available wind power data and wind speed data. The actual wind power data have shown that simple scaling the output of a small wind plant to match the expected output (either power or total energy) of a large wind power plant will exacerbate the fluctuation of wind power. Scaling down the output of a large wind power plant to match the expected output of a smaller wind power plant will have the opposite effect. Simple extrapolating from a single anemometer reading to the output of a wind power plant will produce even worse effect. The resulting wind power profiles from either approach will not show the true behavior of the intended wind power plant. 
APPENDIX A. Statistics of Wind Power Step Changes with 1-Second Data Series

\begin{tabular}{|l|c|c|c|c|c|}
\hline SW Minn. & $\begin{array}{c}\text { Average } \\
(\mathbf{k W})\end{array}$ & $\begin{array}{c}\text { Average } \\
(\% \text { capacity) }\end{array}$ & $\begin{array}{c}\text { Standard } \\
\text { Deviation (kW) }\end{array}$ & $\begin{array}{c}\text { Maximum (+) } \\
\mathbf{( k W )}\end{array}$ & $\begin{array}{c}\text { Maximum (-) } \\
(\mathbf{k W})\end{array}$ \\
\hline July 2001 & 57 & $0.06 \%$ & 92 & 1,602 & $(1,620)$ \\
\hline August & 53 & $0.05 \%$ & 72 & 1,680 & $(1,550)$ \\
\hline September & 72 & $0.07 \%$ & 110 & 2,090 & $(2,040)$ \\
\hline October & 114 & $0.11 \%$ & 157 & 3,060 & $(2,490)$ \\
\hline November & 121 & $0.12 \%$ & 176 & 2,990 & $(2,300)$ \\
\hline December & 105 & $0.10 \%$ & 142 & 2,930 & $(2,200)$ \\
\hline January 2002 & 88 & $0.09 \%$ & 129 & 4,740 & $(4,420)$ \\
\hline February & 133 & $0.13 \%$ & 170 & 3,770 & $(2,460)$ \\
\hline March & 97 & $0.09 \%$ & 138 & 3,090 & $(4,890)$ \\
\hline April & 112 & $0.11 \%$ & 152 & 2,230 & $(9,290)$ \\
\hline May & 99 & $0.10 \%$ & 149 & 2,260 & $(4,040)$ \\
\hline June & 89 & $0.09 \%$ & 132 & 2,400 & $(5,730)$ \\
\hline
\end{tabular}

\begin{tabular}{|l|c|c|c|c|c|}
\hline Storm Lake & $\begin{array}{c}\text { Average } \\
(\mathbf{k W})\end{array}$ & $\begin{array}{c}\text { Average } \\
\text { (\% capacity) }\end{array}$ & $\begin{array}{c}\text { Standard } \\
\text { Deviation (kW) }\end{array}$ & $\begin{array}{c}\text { Maximum (+) } \\
(\mathbf{k W})\end{array}$ & $\begin{array}{c}\text { Maximum (-) } \\
\mathbf{( k W )}\end{array}$ \\
\hline July 2001 & 42 & $0.04 \%$ & 60 & 1,089 & $(5,158)$ \\
\hline August & 43 & $0.04 \%$ & 57 & 1,379 & $(14,466)$ \\
\hline September & 48 & $0.04 \%$ & 69 & 3,950 & $(11,333)$ \\
\hline October & 70 & $0.06 \%$ & 98 & 10,209 & $(1,321)$ \\
\hline November & 63 & $0.06 \%$ & 73 & 955 & $(3,454)$ \\
\hline December & 45 & $0.04 \%$ & 89 & 971 & $(807)$ \\
\hline January 2002 & 60 & $0.06 \%$ & 70 & 887 & $(948)$ \\
\hline February & 77 & $0.07 \%$ & 172 & 4,990 & $(94,138)$ \\
\hline March & 71 & $0.06 \%$ & 128 & 4,444 & $(75,356)$ \\
\hline April & 81 & $0.07 \%$ & 131 & 11,144 & $(95,373)$ \\
\hline May & 74 & $0.07 \%$ & 98 & 8,136 & $(82,246)$ \\
\hline June & 71 & $0.06 \%$ & 93 & 5,590 & $(49,706)$ \\
\hline
\end{tabular}

\begin{tabular}{|l|c|c|c|c|c|}
\hline \multicolumn{7}{|c|}{$\begin{array}{c}\text { Cverage } \\
(\mathbf{k W})\end{array}$} & $\begin{array}{c}\text { Average } \\
(\% \text { capacity) }\end{array}$ & $\begin{array}{c}\text { Standard } \\
\text { Deviation (kW) }\end{array}$ & $\begin{array}{c}\text { Maximum (+) } \\
\mathbf{( k W )}\end{array}$ & $\begin{array}{c}\text { Maximum (-) } \\
\mathbf{( k W )}\end{array}$ \\
\hline July 2001 & 78 & $0.04 \%$ & 106 & 10,652 & $(16,552)$ \\
\hline August & 74 & $0.03 \%$ & 87 & 1,635 & $(14,472)$ \\
\hline September & 95 & $0.04 \%$ & 124 & 4,288 & $(11,433)$ \\
\hline October & 141 & $0.07 \%$ & 180 & 10,669 & $(2,541)$ \\
\hline November & 145 & $0.06 \%$ & 184 & 3,078 & $(3,877)$ \\
\hline December & 100 & $0.05 \%$ & 135 & 1,721 & $(1,631)$ \\
\hline January 2002 & 116 & $0.05 \%$ & 140 & 4,736 & $(4,434)$ \\
\hline February & 162 & $0.07 \%$ & 238 & 5,180 & $(95,105)$ \\
\hline March & 132 & $0.06 \%$ & 181 & 4,382 & $(75,035)$ \\
\hline April & 147 & $0.07 \%$ & 196 & 13,588 & $(95,793)$ \\
\hline May & 131 & $0.06 \%$ & 175 & 37,827 & $(82,266)$ \\
\hline June & 123 & $0.06 \%$ & 156 & 5,560 & $(50,925)$ \\
\hline
\end{tabular}




\begin{tabular}{|l|c|c|c|c|c|}
\hline S Upton & $\begin{array}{c}\text { Average } \\
\mathbf{( k W )}\end{array}$ & $\begin{array}{c}\text { Average } \\
(\% \text { capacity) }\end{array}$ & $\begin{array}{c}\text { Standard } \\
\text { Deviation (kW) }\end{array}$ & $\begin{array}{c}\text { Maximum (+) } \\
\mathbf{( k W )}\end{array}$ & $\begin{array}{c}\text { Maximum (-) } \\
\mathbf{( k W )}\end{array}$ \\
\hline January 2003 & 66 & $0.08 \%$ & 82 & 1,146 & $(23,568)$ \\
\hline February & 83 & $0.10 \%$ & 95 & 1,184 & $(16,136)$ \\
\hline March & 81 & $0.10 \%$ & 97 & 2,929 & $(2,889)$ \\
\hline April & 97 & $0.12 \%$ & 102 & 1,747 & $(2,426)$ \\
\hline May & 71 & $0.09 \%$ & 92 & 2,683 & $(2,607)$ \\
\hline June & 103 & $0.12 \%$ & 109 & 1,959 & $(37,479)$ \\
\hline July & 120 & $0.15 \%$ & 121 & 45,591 & $(26,307)$ \\
\hline August & 102 & $0.12 \%$ & 105 & 3,512 & $(9,445)$ \\
\hline September & 84 & $0.10 \%$ & 98 & 4,898 & $(2,874)$ \\
\hline October & 68 & $0.08 \%$ & 81 & 1,331 & $(3,261)$ \\
\hline November & 79 & $0.10 \%$ & 96 & 2,279 & $(2,394)$ \\
\hline December & 90 & $0.11 \%$ & 103 & 3,316 & $(3,596)$ \\
\hline Year & 87 & $0.11 \%$ & 100 & 45,591 & $(37,479)$ \\
\hline
\end{tabular}

\begin{tabular}{|l|c|c|c|c|c|}
\hline Trent Mesa & $\begin{array}{c}\text { Average } \\
(\mathbf{k W})\end{array}$ & $\begin{array}{c}\text { Average } \\
(\% \text { capacity) }\end{array}$ & $\begin{array}{c}\text { Standard } \\
\text { Deviation (kW) }\end{array}$ & $\begin{array}{c}\text { Maximum (+) } \\
\mathbf{( k W )}\end{array}$ & $\begin{array}{c}\text { Maximum (-) } \\
\mathbf{( k W )}\end{array}$ \\
\hline January 2003 & 74 & $0.05 \%$ & 104 & 1,699 & $(23,649)$ \\
\hline February & 90 & $0.06 \%$ & 159 & 2,883 & $(94,536)$ \\
\hline March & 94 & $0.06 \%$ & 137 & 2,932 & $(71,593)$ \\
\hline April & 108 & $0.07 \%$ & 197 & 2,482 & $(119,337)$ \\
\hline May & 89 & $0.06 \%$ & 122 & 1,975 & $(45,783)$ \\
\hline June & 86 & $0.06 \%$ & 124 & 3,236 & $(38,715)$ \\
\hline July & 74 & $0.05 \%$ & 125 & 4,750 & $(4,978)$ \\
\hline August & 59 & $0.04 \%$ & 98 & 3,198 & $(45,015)$ \\
\hline September & 77 & $0.05 \%$ & 116 & 4,818 & $(53,710)$ \\
\hline October & 73 & $0.05 \%$ & 121 & 7,153 & $(63,789)$ \\
\hline November & 98 & $0.07 \%$ & 133 & 2,634 & $(42,137)$ \\
\hline December & 94 & $0.06 \%$ & 119 & 2,248 & $(3,681)$ \\
\hline Year & 85 & $0.06 \%$ & 133 & 7,153 & $(119,337)$ \\
\hline
\end{tabular}

\begin{tabular}{|l|c|c|c|c|c|}
\hline SW Upton & $\begin{array}{c}\text { Average } \\
(\mathbf{k W})\end{array}$ & $\begin{array}{c}\text { Average } \\
(\% \text { capacity) }\end{array}$ & $\begin{array}{c}\text { Standard } \\
\text { Deviation (kW) }\end{array}$ & $\begin{array}{c}\text { Maximum (+) } \\
\mathbf{( k W )}\end{array}$ & $\begin{array}{c}\text { Maximum (-) } \\
(\mathbf{k W})\end{array}$ \\
\hline January 2003 & 81 & $0.10 \%$ & 94 & 8,061 & $(14,092)$ \\
\hline February & 104 & $0.13 \%$ & 111 & 2,348 & $(3,924)$ \\
\hline March & 111 & $0.14 \%$ & 128 & 2,274 & $(3,578)$ \\
\hline April & 131 & $0.16 \%$ & 143 & 3,595 & $(27,272)$ \\
\hline May & 102 & $0.13 \%$ & 118 & 4,864 & $(31,130)$ \\
\hline June & 114 & $0.14 \%$ & 121 & 2,210 & $(15,650)$ \\
\hline July & 101 & $0.13 \%$ & 105 & 11,738 & $(14,324)$ \\
\hline August & 102 & $0.13 \%$ & 102 & 1,639 & $(29,641)$ \\
\hline September & 98 & $0.12 \%$ & 111 & 1,483 & $(15,237)$ \\
\hline October & 120 & $0.15 \%$ & 117 & 1,403 & $(1,822)$ \\
\hline November & 106 & $0.13 \%$ & 117 & 1,695 & $(2,578)$ \\
\hline December & 119 & $0.15 \%$ & 140 & 1,908 & $(48,520)$ \\
\hline Year & 107 & $0.13 \%$ & 119 & 11,738 & $(48,520)$ \\
\hline
\end{tabular}




\begin{tabular}{|l|c|c|c|c|c|}
\hline TWPP & $\begin{array}{c}\text { Average } \\
\mathbf{( k W )}\end{array}$ & $\begin{array}{c}\text { Average } \\
(\% \text { capacity) }\end{array}$ & $\begin{array}{c}\text { Standard } \\
\text { Deviation (kW) }\end{array}$ & $\begin{array}{c}\text { Maximum (+) } \\
\mathbf{( k W )}\end{array}$ & $\begin{array}{c}\text { Maximum (-) } \\
\mathbf{( k W )}\end{array}$ \\
\hline January 2003 & & & & & \\
\hline February & & & & & \\
\hline March & & & & & \\
\hline April & 32 & $0.09 \%$ & 44 & 806 & $(17,509)$ \\
\hline May & 25 & $0.07 \%$ & 36 & 884 & $(3,684)$ \\
\hline June & 23 & $0.07 \%$ & 46 & 1,532 & $(33,204)$ \\
\hline July & 16 & $0.05 \%$ & 38 & 1,026 & $(31,778)$ \\
\hline August & 18 & $0.05 \%$ & 28 & 964 & $(3,328)$ \\
\hline September & 17 & $0.05 \%$ & 26 & 837 & $(1,009)$ \\
\hline October & 18 & $0.05 \%$ & 30 & 829 & $(1,293)$ \\
\hline November & 26 & $0.07 \%$ & 37 & 886 & $(14,357)$ \\
\hline December & 31 & $0.09 \%$ & 42 & 603 & $(1,765)$ \\
\hline Year & 22 & $0.06 \%$ & 37 & 1,532 & $(33,204)$ \\
\hline
\end{tabular}

\begin{tabular}{|l|c|c|c|c|c|}
\hline \multicolumn{7}{|c|}{ Four Texas Wind Farms Combined } \\
\hline & $\begin{array}{c}\text { Average } \\
(\mathbf{k W})\end{array}$ & $\begin{array}{c}\text { Average } \\
(\% \text { capacity) }\end{array}$ & $\begin{array}{c}\text { Standard } \\
\text { Deviation (kW) }\end{array}$ & $\begin{array}{c}\text { Maximum (+) } \\
(\mathbf{k W})\end{array}$ & $\begin{array}{c}\text { Maximum (-) } \\
(\mathbf{k W})\end{array}$ \\
\hline January 2003 & 130 & $0.04 \%$ & 154 & 8,182 & $(88,315)$ \\
\hline February & 166 & $0.05 \%$ & 201 & 27,789 & $(94,873)$ \\
\hline March & 181 & $0.05 \%$ & 197 & 2,926 & $(72,078)$ \\
\hline April & 212 & $0.06 \%$ & 251 & 3,707 & $(119,028)$ \\
\hline May & 161 & $0.05 \%$ & 171 & 19,829 & $(46,147)$ \\
\hline June & 194 & $0.06 \%$ & 199 & 9,401 & $(38,213)$ \\
\hline July & 186 & $0.05 \%$ & 188 & 45,585 & $(31,970)$ \\
\hline August & 171 & $0.05 \%$ & 165 & 3,745 & $(45,613)$ \\
\hline September & 165 & $0.05 \%$ & 178 & 4,725 & $(53,711)$ \\
\hline October & 121 & $0.03 \%$ & 149 & 7,153 & $(63,827)$ \\
\hline November & 182 & $0.05 \%$ & 190 & 3,282 & $(42,315)$ \\
\hline December & 195 & $0.06 \%$ & 195 & 3,732 & $(48,857)$ \\
\hline Year & 172 & $0.05 \%$ & 190 & 45,585 & $(119,028)$ \\
\hline
\end{tabular}

\begin{tabular}{|l|c|c|c|c|c|}
\hline \multicolumn{7}{|c|}{ Midwest and Texas Combined } \\
\hline & $\begin{array}{c}\text { Average } \\
\text { (kW) }\end{array}$ & $\begin{array}{c}\text { Average } \\
\text { (\% capacity) }\end{array}$ & $\begin{array}{c}\text { Standard } \\
\text { Deviation (kW) }\end{array}$ & $\begin{array}{c}\text { Maximum (+) } \\
\text { (kW) }\end{array}$ & $\begin{array}{c}\text { Maximum (-) } \\
\text { (kW) }\end{array}$ \\
\hline January 2003 & 190 & $0.03 \%$ & 191 & 35,039 & $(88,384)$ \\
\hline February & 222 & $0.04 \%$ & 263 & 27,816 & $(94,858)$ \\
\hline March & 230 & $0.04 \%$ & 225 & 54,388 & $(71,953)$ \\
\hline April & 259 & $0.05 \%$ & 287 & 10,695 & $(119,000)$ \\
\hline May & 206 & $0.04 \%$ & 201 & 19,895 & $(46,296)$ \\
\hline June & 223 & $0.04 \%$ & 218 & 9,324 & $(41,803)$ \\
\hline July & 222 & $0.04 \%$ & 209 & 45,642 & $(34,462)$ \\
\hline August & 198 & $0.04 \%$ & 182 & 3,709 & $(45,604)$ \\
\hline September & 214 & $0.04 \%$ & 208 & 4,513 & $(53,747)$ \\
\hline October & 179 & $0.03 \%$ & 179 & 7,087 & $(63,771)$ \\
\hline November & 241 & $0.04 \%$ & 240 & 4,037 & $(66,171)$ \\
\hline December & 245 & $0.04 \%$ & 246 & 6,453 & $(51,242)$ \\
\hline Year & 219 & $0.04 \%$ & 224 & 54,388 & $(119,000)$ \\
\hline
\end{tabular}


APPENDIX B. Statistics of Wind Power Step Changes with 1-Minute Data Series

\begin{tabular}{|l|c|c|c|c|c|}
\hline SW Minn. & $\begin{array}{c}\text { Average } \\
(\mathbf{k W})\end{array}$ & $\begin{array}{c}\text { Average } \\
\text { (\% capacity) }\end{array}$ & $\begin{array}{c}\text { Standard } \\
\text { Deviation (kW) }\end{array}$ & $\begin{array}{c}\text { Maximum (+) } \\
\text { (MW) }\end{array}$ & $\begin{array}{c}\text { Maximum (-) } \\
\text { (MW) }\end{array}$ \\
\hline July 2001 & 399 & $0.4 \%$ & 565 & 16.9 & $(7.9)$ \\
\hline August & 384 & $0.4 \%$ & 541 & 22.7 & $(19.4)$ \\
\hline September & 384 & $0.4 \%$ & 509 & 7.9 & $(5.5)$ \\
\hline October & 549 & $0.5 \%$ & 672 & 7.8 & $(6.5)$ \\
\hline November & 434 & $0.4 \%$ & 530 & 14.6 & $(12.0)$ \\
\hline December & 464 & $0.5 \%$ & 518 & 12.2 & $(8.2)$ \\
\hline January 2002 & 475 & $0.5 \%$ & 535 & 5.6 & $(4.8)$ \\
\hline February & 491 & $0.5 \%$ & 591 & 17.4 & $(21.4)$ \\
\hline March & 449 & $0.4 \%$ & 582 & 6.6 & $(20.0)$ \\
\hline April & 564 & $0.5 \%$ & 856 & 14.7 & $(27.6)$ \\
\hline May & 554 & $0.5 \%$ & 819 & 18.0 & $(28.5)$ \\
\hline June & 631 & $0.6 \%$ & 937 & 16.3 & $(21.7)$ \\
\hline 12-month & 481 & $0.5 \%$ & 657 & 22.7 & $(28.5)$ \\
\hline
\end{tabular}

\begin{tabular}{|l|c|c|c|c|c|}
\hline Storm Lake & $\begin{array}{c}\text { Average } \\
\text { (kW) }\end{array}$ & $\begin{array}{c}\text { Average } \\
(\% \text { capacity) }\end{array}$ & $\begin{array}{c}\text { Standard } \\
\text { Deviation (kW) }\end{array}$ & $\begin{array}{c}\text { Maximum (+) } \\
\text { (MW) }\end{array}$ & $\begin{array}{c}\text { Maximum (-) } \\
\text { (MW) }\end{array}$ \\
\hline July 2001 & 351 & $0.3 \%$ & 508 & 11.8 & $(8.1)$ \\
\hline August & 319 & $0.3 \%$ & 481 & 15.6 & $(12.0)$ \\
\hline September & 324 & $0.3 \%$ & 474 & 6.3 & $(9.0)$ \\
\hline October & 495 & $0.4 \%$ & 612 & 7.6 & $(7.6)$ \\
\hline November & 438 & $0.4 \%$ & 489 & 6.4 & $(6.7)$ \\
\hline December & 369 & $0.3 \%$ & 385 & 3.9 & $(3.0)$ \\
\hline January 2002 & 448 & $0.4 \%$ & 508 & 6.0 & $(5.8)$ \\
\hline February & 506 & $0.4 \%$ & 1,357 & 62.7 & $(81.3)$ \\
\hline March & 489 & $0.4 \%$ & 996 & 55.4 & $(85.6)$ \\
\hline April & 563 & $0.5 \%$ & 748 & 15.7 & $(48.1)$ \\
\hline May & 570 & $0.5 \%$ & 835 & 28.5 & $(81.7)$ \\
\hline June & 552 & $0.5 \%$ & 760 & 17.1 & $(63.7)$ \\
\hline 12-month & 457 & $0.4 \%$ & 748 & 62.7 & $(85.6)$ \\
\hline
\end{tabular}

\begin{tabular}{|l|c|c|c|c|c|}
\hline \multicolumn{7}{|c|}{ Combined SW Minn. and Storm Lake } \\
\hline & $\begin{array}{c}\text { Average } \\
(\mathbf{k W})\end{array}$ & $\begin{array}{c}\text { Average } \\
(\% \text { capacity) }\end{array}$ & $\begin{array}{c}\text { Standard } \\
\text { Deviation (kW) }\end{array}$ & $\begin{array}{c}\text { Maximum (+) } \\
\text { (MW) }\end{array}$ & $\begin{array}{c}\text { Maximum (-) } \\
\text { (MW) }\end{array}$ \\
\hline July 2001 & 576 & $0.3 \%$ & 736 & 17.2 & $(10.4)$ \\
\hline August & 542 & $0.3 \%$ & 705 & 22.0 & $(18.5)$ \\
\hline September & 534 & $0.2 \%$ & 672 & 7.0 & $(9.8)$ \\
\hline October & 777 & $0.4 \%$ & 878 & 10.3 & $(9.0)$ \\
\hline November & 661 & $0.3 \%$ & 692 & 15.8 & $(11.0)$ \\
\hline December & 589 & $0.3 \%$ & 567 & 4.7 & $(4.7)$ \\
\hline January 2002 & 695 & $0.3 \%$ & 703 & 8.3 & $(5.7)$ \\
\hline February & 764 & $0.4 \%$ & 1,465 & 63.5 & $(81.4)$ \\
\hline March & 711 & $0.3 \%$ & 1,126 & 55.5 & $(85.7)$ \\
\hline April & 849 & $0.4 \%$ & 1,119 & 20.5 & $(78.5)$ \\
\hline May & 846 & $0.4 \%$ & 1,135 & 28.5 & $(82.0)$ \\
\hline June & 883 & $0.4 \%$ & 1,176 & 16.7 & $(63.8)$ \\
\hline 12-month & 709 & $0.3 \%$ & 976 & 63.5 & $(85.7)$ \\
\hline
\end{tabular}




\begin{tabular}{|l|c|c|c|c|c|}
\hline S Upton & $\begin{array}{c}\text { Average } \\
\text { (kW) }\end{array}$ & $\begin{array}{c}\text { Average } \\
\text { (\% capacity) }\end{array}$ & $\begin{array}{c}\text { Standard } \\
\text { Deviation (kW) }\end{array}$ & $\begin{array}{c}\text { Maximum (+) } \\
\text { (MW) }\end{array}$ & $\begin{array}{c}\text { Maximum (-) } \\
\text { (MW) }\end{array}$ \\
\hline January 2003 & 314 & $0.4 \%$ & 581 & 15.5 & $(16.5)$ \\
\hline February & 411 & $0.5 \%$ & 707 & 27.2 & $(38.5)$ \\
\hline March & 420 & $0.5 \%$ & 788 & 19.8 & $(34.1)$ \\
\hline April & 434 & $0.5 \%$ & 610 & 16.5 & $(22.1)$ \\
\hline May & 388 & $0.5 \%$ & 748 & 14.5 & $(22.1)$ \\
\hline June & 564 & $0.7 \%$ & 952 & 19.3 & $(38.9)$ \\
\hline July & 571 & $0.7 \%$ & 728 & 29.0 & $(27.2)$ \\
\hline August & 491 & $0.6 \%$ & 663 & 17.7 & $(21.4)$ \\
\hline September & 370 & $0.5 \%$ & 617 & 30.7 & $(24.7)$ \\
\hline October & 305 & $0.4 \%$ & 521 & 15.3 & $(19.1)$ \\
\hline November & 336 & $0.4 \%$ & 667 & 29.7 & $(39.9)$ \\
\hline December & 362 & $0.4 \%$ & 582 & 41.0 & $(39.4)$ \\
\hline Year & 401 & $0.5 \%$ & 694 & 41.0 & $(39.4)$ \\
\hline
\end{tabular}

\begin{tabular}{|l|c|c|c|c|c|}
\hline Trent Mesa & $\begin{array}{c}\text { Average } \\
(\mathbf{k W})\end{array}$ & $\begin{array}{c}\text { Average } \\
(\% \text { capacity) }\end{array}$ & $\begin{array}{c}\text { Standard } \\
\text { Deviation (kW) }\end{array}$ & $\begin{array}{c}\text { Maximum (+) } \\
(\mathbf{M W})\end{array}$ & $\begin{array}{c}\text { Maximum (-) } \\
(\mathbf{M W})\end{array}$ \\
\hline January 2003 & 685 & $0.5 \%$ & 961 & 12.8 & $(46.1)$ \\
\hline February & 855 & $0.6 \%$ & 1,360 & 36.4 & $(83.4)$ \\
\hline March & 968 & $0.7 \%$ & 1,379 & 46.0 & $(81.3)$ \\
\hline April & 1,090 & $0.7 \%$ & 1,552 & 62.3 & $(96.8)$ \\
\hline May & 969 & $0.7 \%$ & 1,234 & 21.8 & $(19.3)$ \\
\hline June & 908 & $0.6 \%$ & 1,328 & 30.6 & $(33.2)$ \\
\hline July & 745 & $0.5 \%$ & 929 & 81.3 & $(8.8)$ \\
\hline August & 643 & $0.4 \%$ & 969 & 34.4 & $(37.0)$ \\
\hline September & 722 & $0.5 \%$ & 1,001 & 27.6 & $(35.6)$ \\
\hline October & 673 & $0.5 \%$ & 1,047 & 38.2 & $(36.8)$ \\
\hline November & 824 & $0.5 \%$ & 1,136 & 25.0 & $(55.3)$ \\
\hline December & 745 & $0.5 \%$ & 1,131 & 34.9 & $(35.5)$ \\
\hline Year & 821 & $0.6 \%$ & 1,194 & 81.3 & $(96.8)$ \\
\hline
\end{tabular}

\begin{tabular}{|l|c|c|c|c|c|}
\hline SW Upton & $\begin{array}{c}\text { Average } \\
\text { (kW) }\end{array}$ & $\begin{array}{c}\text { Average } \\
\text { (\% capacity) }\end{array}$ & $\begin{array}{c}\text { Standard } \\
\text { Deviation (kW) }\end{array}$ & $\begin{array}{c}\text { Maximum (+) } \\
\text { (MW) }\end{array}$ & $\begin{array}{c}\text { Maximum (-) } \\
\text { (MW) }\end{array}$ \\
\hline January 2003 & 389 & $0.5 \%$ & 535 & 9.4 & $(9.8)$ \\
\hline February & 576 & $0.7 \%$ & 743 & 16.0 & $(14.0)$ \\
\hline March & 629 & $0.8 \%$ & 944 & 18.8 & $(12.6)$ \\
\hline April & 731 & $0.9 \%$ & 959 & 14.2 & $(35.9)$ \\
\hline May & 689 & $0.9 \%$ & 1,041 & 24.2 & $(30.9)$ \\
\hline June & 750 & $0.9 \%$ & 995 & 24.4 & $(26.0)$ \\
\hline July & 705 & $0.9 \%$ & 894 & 18.2 & $(14.5)$ \\
\hline August & 632 & $0.8 \%$ & 824 & 10.9 & $(26.9)$ \\
\hline September & 561 & $0.7 \%$ & 750 & 14.5 & $(20.9)$ \\
\hline October & 523 & $0.7 \%$ & 642 & 6.7 & $(12.0)$ \\
\hline November & 509 & $0.6 \%$ & 667 & 10.2 & $(10.5)$ \\
\hline December & 513 & $0.6 \%$ & 667 & 10.9 & $(10.6)$ \\
\hline Year & 606 & $0.8 \%$ & 838 & 24.4 & $(35.9)$ \\
\hline
\end{tabular}




\begin{tabular}{|l|c|c|c|c|c|}
\hline TWPP & $\begin{array}{c}\text { Average } \\
\text { (kW) }\end{array}$ & $\begin{array}{c}\text { Average } \\
\text { (\% capacity) }\end{array}$ & $\begin{array}{c}\text { Standard } \\
\text { Deviation (kW) }\end{array}$ & $\begin{array}{c}\text { Maximum (+) } \\
\text { (MW) }\end{array}$ & $\begin{array}{c}\text { Maximum (-) } \\
\text { (MW) }\end{array}$ \\
\hline January 2003 & & & & & \\
\hline February & & & & & \\
\hline March & & & & 11.2 & $(18.0)$ \\
\hline April & 347 & $1.0 \%$ & 580 & 9.7 & $(10.0)$ \\
\hline May & 275 & $0.8 \%$ & 455 & 13.9 & $(34.9)$ \\
\hline June & 349 & $1.0 \%$ & 590 & 7.0 & $(19.7)$ \\
\hline July & 273 & $0.8 \%$ & 520 & 10.0 & $(7.7)$ \\
\hline August & 298 & $0.9 \%$ & 522 & 7.9 & $(5.0)$ \\
\hline September & 250 & $0.7 \%$ & 411 & 7.6 & $(4.8)$ \\
\hline October & 167 & $0.5 \%$ & 278 & 12.2 & $(11.5)$ \\
\hline November & 224 & $0.6 \%$ & 319 & 12.0 & $(15.3)$ \\
\hline December & 239 & $0.7 \%$ & 417 & 13.9 & $(34.9)$ \\
\hline Year & 272 & $0.8 \%$ & 473 & &
\end{tabular}

\begin{tabular}{|l|r|c|c|c|c|}
\hline \multicolumn{7}{|c|}{ Four Texas Wind Farms Combined } \\
\hline & $\begin{array}{c}\text { Average } \\
\text { (kW) }\end{array}$ & $\begin{array}{c}\text { Average } \\
\text { (\% capacity) }\end{array}$ & $\begin{array}{c}\text { Standard } \\
\text { Deviation (kW) }\end{array}$ & $\begin{array}{c}\text { Maximum (+) } \\
\text { (MW) }\end{array}$ & $\begin{array}{c}\text { Maximum (-) } \\
\text { (MW) }\end{array}$ \\
\hline January 2003 & 825 & $0.2 \%$ & 1,083 & 15.7 & $(45.9)$ \\
\hline February & 1,207 & $0.3 \%$ & 1,580 & 41.0 & $(83.5)$ \\
\hline March & 1,370 & $0.4 \%$ & 1,737 & 44.9 & $(80.6)$ \\
\hline April & 1,634 & $0.5 \%$ & 1,917 & 61.8 & $(97.0)$ \\
\hline May & 1,391 & $0.4 \%$ & 1,622 & 21.9 & $(32.0)$ \\
\hline June & 1,551 & $0.4 \%$ & 1,856 & 30.8 & $(32.6)$ \\
\hline July & 1,334 & $0.4 \%$ & 1,454 & 79.2 & $(28.1)$ \\
\hline August & 1,253 & $0.3 \%$ & 1,402 & 34.4 & $(36.9)$ \\
\hline September & 1,184 & $0.5 \%$ & 1,348 & 31.4 & $(35.2)$ \\
\hline October & 878 & $0.3 \%$ & 1,163 & 36.8 & $(37.9)$ \\
\hline November & 1,183 & $0.3 \%$ & 1,411 & 25.4 & $(56.0)$ \\
\hline December & 1,126 & $0.3 \%$ & 1,379 & 40.8 & $(47.0)$ \\
\hline Year & 1,241 & $0.4 \%$ & 1,531 & 79.2 & $(97.0)$ \\
\hline
\end{tabular}

\begin{tabular}{|l|c|c|c|c|c|}
\hline \multicolumn{7}{|c|}{ Midwest and Texas Plants Combined } \\
\hline & $\begin{array}{c}\text { Average } \\
\text { (kW) }\end{array}$ & $\begin{array}{c}\text { Average } \\
(\% \text { capacity) }\end{array}$ & $\begin{array}{c}\text { Standard } \\
\text { Deviation (kW) }\end{array}$ & $\begin{array}{c}\text { Maximum (+) } \\
\text { (MW) }\end{array}$ & $\begin{array}{c}\text { Maximum (-) } \\
\text { (MW) }\end{array}$ \\
\hline January 2003 & 1,164 & $0.2 \%$ & 1,198 & 16.9 & $(45.9)$ \\
\hline February & 1,516 & $0.3 \%$ & 2,134 & 75.7 & $(90.5)$ \\
\hline March & 1,614 & $0.3 \%$ & 1,833 & 45.1 & $(79.5)$ \\
\hline April & 1,897 & $0.3 \%$ & 2,208 & 62.8 & $(96.7)$ \\
\hline May & 1,652 & $0.3 \%$ & 1,811 & 47.0 & $(32.8)$ \\
\hline June & 1,780 & $0.3 \%$ & 1,994 & 30.5 & $(43.7)$ \\
\hline July & 1,614 & $0.3 \%$ & 1,607 & 80.2 & $(32.0)$ \\
\hline August & 1,391 & $0.2 \%$ & 1,507 & 34.5 & $(38.9)$ \\
\hline September & 1,481 & $0.3 \%$ & 1,581 & 31.2 & $(33.3)$ \\
\hline October & 1,194 & $0.2 \%$ & 1,338 & 37.2 & $(37.7)$ \\
\hline November & 1,434 & $0.3 \%$ & 1,828 & 76.9 & $(90.1)$ \\
\hline December & 1,379 & $0.2 \%$ & 1,779 & 43.5 & $(85.7)$ \\
\hline Year & 1,508 & $0.3 \%$ & 1,767 & 80.2 & $(96.7)$ \\
\hline
\end{tabular}


APPENDIX C. Statistics of Wind Power Step Changes with 10-Minute Data Series

\begin{tabular}{|l|c|c|c|c|c|}
\hline SW Minn. & $\begin{array}{c}\text { Average } \\
(\mathbf{k W})\end{array}$ & $\begin{array}{c}\text { Average } \\
\text { (\% capacity) }\end{array}$ & $\begin{array}{c}\text { Standard } \\
\text { Deviation (kW) }\end{array}$ & $\begin{array}{c}\text { Maximum (+) } \\
\text { (MW) }\end{array}$ & $\begin{array}{c}\text { Maximum (-) } \\
(\mathbf{M W})\end{array}$ \\
\hline July 2001 & 1,849 & $1.8 \%$ & 2,552 & 45.0 & $(25.6)$ \\
\hline August & 1,832 & $1.8 \%$ & 2,457 & 38.7 & $(26.6)$ \\
\hline September & 1,608 & $1.6 \%$ & 2,169 & 28.4 & $(28.4)$ \\
\hline October & 2,396 & $2.3 \%$ & 3,050 & 36.8 & $(31.3)$ \\
\hline November & 2,146 & $2.1 \%$ & 2,675 & 43.4 & $(25.0)$ \\
\hline December & 2,458 & $2.4 \%$ & 2,773 & 27.5 & $(34.4)$ \\
\hline January 2002 & 2,509 & $2.4 \%$ & 2,810 & 28.7 & $(16.2)$ \\
\hline February & 2,211 & $2.1 \%$ & 2,923 & 48.5 & $(55.3)$ \\
\hline March & 2,022 & $2.0 \%$ & 2,618 & 43.5 & $(27.5)$ \\
\hline April & 2,214 & $2.1 \%$ & 2,931 & 29.5 & $(30.6)$ \\
\hline May & 2,440 & $2.4 \%$ & 3,281 & 28.9 & $(32.9)$ \\
\hline June & 2,715 & $2.6 \%$ & 3,533 & 33.3 & $(35.5)$ \\
\hline 12-month & 2,200 & $2.1 \%$ & 2,853 & 48.5 & $(55.3)$ \\
\hline
\end{tabular}

\begin{tabular}{|l|c|c|c|c|c|}
\hline Storm Lake & $\begin{array}{c}\text { Average } \\
\text { (kW) }\end{array}$ & $\begin{array}{c}\text { Average } \\
\text { (\% capacity) }\end{array}$ & $\begin{array}{c}\text { Standard } \\
\text { Deviation (kW) }\end{array}$ & $\begin{array}{c}\text { Maximum (+) } \\
\text { (MW) }\end{array}$ & $\begin{array}{c}\text { Maximum (-) } \\
(\mathbf{M W})\end{array}$ \\
\hline July 2001 & 1,803 & $1.6 \%$ & 2,774 & 34.1 & $(40.4)$ \\
\hline August & 1,748 & $1.5 \%$ & 2,734 & 47.2 & $(29.3)$ \\
\hline September & 1,622 & $1.4 \%$ & 2,417 & 31.0 & $(41.1)$ \\
\hline October & 2,115 & $1.9 \%$ & 2,610 & 27.0 & $(26.6)$ \\
\hline November & 2,158 & $1.9 \%$ & 2,432 & 25.3 & $(29.2)$ \\
\hline December & 2,111 & $1.9 \%$ & 2,020 & 14.9 & $(15.8)$ \\
\hline January 2002 & 2,343 & $2.1 \%$ & 2,627 & 31.2 & $(20.1)$ \\
\hline February & 2,473 & $2.2 \%$ & 3,996 & 88.6 & $(71.3)$ \\
\hline March & 2,165 & $1.9 \%$ & 3,734 & 81.8 & $(75.6)$ \\
\hline April & 2,481 & $2.2 \%$ & 4,477 & 94.6 & $(96.8)$ \\
\hline May & 2,543 & $2.2 \%$ & 3,692 & 50.1 & $(87.6)$ \\
\hline June & 2,231 & $2.0 \%$ & 3,267 & 34.2 & $(52.1)$ \\
\hline 12-month & 2,150 & $1.9 \%$ & 3,219 & 94.6 & $(96.8)$ \\
\hline
\end{tabular}

\begin{tabular}{|l|c|c|c|c|c|}
\hline \multicolumn{7}{|c|}{ Combined SW Minn. and Storm Lake } \\
\hline & $\begin{array}{c}\text { Average } \\
(\mathbf{k W})\end{array}$ & $\begin{array}{c}\text { Average } \\
(\% \text { capacity) }\end{array}$ & $\begin{array}{c}\text { Standard } \\
\text { Deviation (kW) }\end{array}$ & $\begin{array}{c}\text { Maximum (+) } \\
(\mathbf{M W})\end{array}$ & $\begin{array}{c}\text { Maximum (-) } \\
\text { (MW) }\end{array}$ \\
\hline July 2001 & 2,824 & $1.3 \%$ & 3,644 & 46.0 & $(40.5)$ \\
\hline August & 2,804 & $1.3 \%$ & 3,646 & 49.2 & $(33.2)$ \\
\hline September & 2,509 & $1.2 \%$ & 3,097 & 27.7 & $(40.7)$ \\
\hline October & 3,500 & $1.6 \%$ & 3,837 & 35.9 & $(47.7)$ \\
\hline November & 3,376 & $1.6 \%$ & 3,487 & 42.5 & $(29.1)$ \\
\hline December & 3,505 & $1.6 \%$ & 4,179 & 82.2 & $(22.5)$ \\
\hline January 2002 & 3,687 & $1.7 \%$ & 3,671 & 38.4 & $(23.8)$ \\
\hline February & 3,714 & $1.7 \%$ & 4,880 & 89.2 & $(71.3)$ \\
\hline March & 3,291 & $1.5 \%$ & 4,383 & 81.8 & $(76.4)$ \\
\hline April & 3,729 & $1.7 \%$ & 5,039 & 81.2 & $(91.5)$ \\
\hline May & 3,981 & $1.8 \%$ & 4,979 & 50.8 & $(88.4)$ \\
\hline June & 3,920 & $1.8 \%$ & 5,108 & 51.8 & $(61.0)$ \\
\hline 12-month & 3,393 & $1.6 \%$ & 4,235 & 89.2 & $(91.5)$ \\
\hline S Upton & Average & Average & Standard & Maximum (+) & Maximum (-) \\
\hline
\end{tabular}




\begin{tabular}{|l|c|c|c|c|c|}
\hline & $\mathbf{( k W )}$ & $\mathbf{( \% ~ c a p a c i t y ) ~}$ & Deviation (kW) & $\mathbf{( M W )}$ & $\mathbf{( M W )}$ \\
\hline January 2003 & 1,374 & $1.7 \%$ & 2,104 & 22.3 & $(19.6)$ \\
\hline February & 1,851 & $2.2 \%$ & 2,708 & 33.0 & $(31.4)$ \\
\hline March & 1,670 & $2.0 \%$ & 2,551 & 35.8 & $(30.8)$ \\
\hline April & 1,817 & $2.2 \%$ & 2,723 & 35.4 & $(24.5)$ \\
\hline May & 1,640 & $2.0 \%$ & 2,977 & 34.5 & $(23.7)$ \\
\hline June & 2,401 & $2.9 \%$ & 3,653 & 49.3 & $(39.2)$ \\
\hline July & 2,104 & $2.6 \%$ & 2,489 & 34.6 & $(25.9)$ \\
\hline August & 1,862 & $2.3 \%$ & 2,497 & 46.3 & $(22.8)$ \\
\hline September & 1,402 & $1.7 \%$ & 2,319 & 39.3 & $(30.0)$ \\
\hline October & 1,335 & $1.6 \%$ & 2,063 & 25.7 & $(26.3)$ \\
\hline November & 1,281 & $1.6 \%$ & 2,478 & 31.5 & $(42.0)$ \\
\hline December & 1,205 & $1.5 \%$ & 2,075 & 27.3 & $(23.6)$ \\
\hline Year & 1,588 & $1.9 \%$ & 2,557 & 49.3 & $(42.0)$ \\
\hline
\end{tabular}

\begin{tabular}{|l|c|c|c|c|c|}
\hline Trent Mesa & $\begin{array}{c}\text { Average } \\
(\mathbf{k W})\end{array}$ & $\begin{array}{c}\text { Average } \\
\text { (\% capacity) }\end{array}$ & $\begin{array}{c}\text { Standard } \\
\text { Deviation (kW) }\end{array}$ & $\begin{array}{c}\text { Maximum (+) } \\
(\mathbf{M W})\end{array}$ & $\begin{array}{c}\text { Maximum (-) } \\
\text { (MW) }\end{array}$ \\
\hline January 2003 & 3,052 & $2.0 \%$ & 4,276 & 32.9 & $(78.6)$ \\
\hline February & 3,424 & $2.3 \%$ & 4,733 & 40.5 & $(75.8)$ \\
\hline March & 3,592 & $2.4 \%$ & 4,701 & 53.6 & $(64.5)$ \\
\hline April & 3,824 & $2.5 \%$ & 5,206 & 52.8 & $(60.7)$ \\
\hline May & 3,747 & $2.5 \%$ & 5,354 & 61.7 & $(56.9)$ \\
\hline June & 4,056 & $2.7 \%$ & 7,145 & 78.8 & $(87.9)$ \\
\hline July & 3,026 & $2.0 \%$ & 3,687 & 61.6 & $(38.8)$ \\
\hline August & 2,745 & $1.8 \%$ & 4,842 & 95.3 & $(56.8)$ \\
\hline September & 2,585 & $1.7 \%$ & 3,615 & 44.9 & $(57.9)$ \\
\hline October & 2,686 & $1.8 \%$ & 4,077 & 62.9 & $(62.7)$ \\
\hline November & 2,641 & $1.8 \%$ & 3,587 & 32.6 & $(35.4)$ \\
\hline December & 2,680 & $1.8 \%$ & 3,975 & 41.5 & $(52.2)$ \\
\hline Year & 3,170 & $2.1 \%$ & 4,732 & 95.3 & $(87.9)$ \\
\hline
\end{tabular}

\begin{tabular}{|l|c|c|c|c|c|}
\hline SW Upton & $\begin{array}{c}\text { Average } \\
(\mathbf{k W})\end{array}$ & $\begin{array}{c}\text { Average } \\
\text { (\% capacity) }\end{array}$ & $\begin{array}{c}\text { Standard } \\
\text { Deviation (kW) }\end{array}$ & $\begin{array}{c}\text { Maximum (+) } \\
(\mathbf{M W})\end{array}$ & $\begin{array}{c}\text { Maximum (-) } \\
(\mathbf{M W})\end{array}$ \\
\hline January 2003 & 1,077 & $1.4 \%$ & 1,353 & 19.6 & $(22.4)$ \\
\hline February & 1,786 & $2.3 \%$ & 2,193 & 27.2 & $(26.5)$ \\
\hline March & 1,672 & $2.1 \%$ & 2,256 & 33.0 & $(25.9)$ \\
\hline April & 1,716 & $2.2 \%$ & 2,492 & 34.7 & $(36.7)$ \\
\hline May & 1,804 & $2.3 \%$ & 2,554 & 50.6 & $(30.2)$ \\
\hline June & 2,113 & $2.7 \%$ & 2,743 & 26.3 & $(24.2)$ \\
\hline July & 1,775 & $2.2 \%$ & 2,045 & 31.2 & $(13.1)$ \\
\hline August & 1,875 & $2.4 \%$ & 2,421 & 36.2 & $(34.1)$ \\
\hline September & 1,480 & $1.9 \%$ & 2,041 & 32.3 & $(23.4)$ \\
\hline October & 1,289 & $1.6 \%$ & 1,564 & 7.3 & $(20.8)$ \\
\hline November & 1,340 & $1.7 \%$ & 1,583 & 24.4 & $(15.7)$ \\
\hline December & 1,566 & $2.0 \%$ & 1,949 & 22.5 & $(28.4)$ \\
\hline Year & 1,648 & $2.1 \%$ & 2,192 & 50.6 & $(36.7)$ \\
\hline
\end{tabular}




\begin{tabular}{|l|c|c|c|c|c|}
\hline TWPP & $\begin{array}{c}\text { Average } \\
\mathbf{( k W )}\end{array}$ & $\begin{array}{c}\text { Average } \\
(\% \text { capacity) }\end{array}$ & $\begin{array}{c}\text { Standard } \\
\text { Deviation (kW) }\end{array}$ & $\begin{array}{c}\text { Maximum (+) } \\
(\mathbf{M W})\end{array}$ & $\begin{array}{c}\text { Maximum (-) } \\
(\mathbf{M W})\end{array}$ \\
\hline January 2003 & & & & & \\
\hline February & & & & & \\
\hline March & & & & 16.5 & $(18.9)$ \\
\hline April & 896 & $2.6 \%$ & 1,404 & 18.8 & $(8.5)$ \\
\hline May & 722 & $2.1 \%$ & 1,147 & 21.6 & $(33.7)$ \\
\hline June & 993 & $2.8 \%$ & 1,709 & 17.6 & $(19.6)$ \\
\hline July & 590 & $1.7 \%$ & 1,050 & 10.3 & $(7.6)$ \\
\hline August & 730 & $2.1 \%$ & 1,018 & 16.6 & $(12.3)$ \\
\hline September & 581 & $1.7 \%$ & 903 & 23.1 & $(6.9)$ \\
\hline October & 531 & $1.5 \%$ & 932 & 23.3 & $(9.7)$ \\
\hline November & 680 & $1.9 \%$ & 930 & 19.1 & $(20.0)$ \\
\hline December & 864 & $2.5 \%$ & 1,489 & 23.3 & $(33.8)$ \\
\hline Year & 724 & $2.1 \%$ & 1,197 & & \\
\hline
\end{tabular}

\begin{tabular}{|l|c|c|c|c|c|}
\hline \multicolumn{7}{|c|}{ Four Texas Plants Combined } \\
\hline & $\begin{array}{c}\text { Average } \\
\text { (kW) }\end{array}$ & $\begin{array}{c}\text { Average } \\
\text { (\% capacity) }\end{array}$ & $\begin{array}{c}\text { Standard } \\
\text { Deviation (kW) }\end{array}$ & $\begin{array}{c}\text { Maximum (+) } \\
\text { (MW) }\end{array}$ & $\begin{array}{c}\text { Maximum (-) } \\
\text { (MW) }\end{array}$ \\
\hline January 2003 & 3,369 & $1.0 \%$ & 4,254 & 34.0 & $(77.8)$ \\
\hline February & 4,834 & $1.4 \%$ & 5,623 & 53.5 & $(78.6)$ \\
\hline March & 4,837 & $1.4 \%$ & 5,480 & 60.6 & $(65.4)$ \\
\hline April & 5,305 & $1.5 \%$ & 6,136 & 72.2 & $(62.8)$ \\
\hline May & 4,935 & $1.4 \%$ & 5,917 & 71.7 & $(63.7)$ \\
\hline June & 6,085 & $1.7 \%$ & 8,159 & 84.4 & $(86.1)$ \\
\hline July & 4,636 & $1.3 \%$ & 4,743 & 64.5 & $(38.7)$ \\
\hline August & 4,442 & $1.3 \%$ & 5,747 & 102.9 & $(60.0)$ \\
\hline September & 3,831 & $1.1 \%$ & 4,616 & 43.8 & $(59.0)$ \\
\hline October & 3,511 & $1.0 \%$ & 4,514 & 62.5 & $(62.1)$ \\
\hline November & 3,945 & $1.1 \%$ & 4,491 & 36.2 & $(40.6)$ \\
\hline December & 4,069 & $1.2 \%$ & 4,646 & 39.8 & $(55.9)$ \\
\hline Year & 4,476 & $1.3 \%$ & 5,504 & 102.9 & $(86.1)$ \\
\hline
\end{tabular}

\begin{tabular}{|l|c|c|c|c|c|}
\hline \multicolumn{7}{|c|}{ Midwest and Texas Plants Combined } \\
\hline & $\begin{array}{c}\text { Average } \\
(\mathbf{k W})\end{array}$ & $\begin{array}{c}\text { Average } \\
(\% \text { capacity) }\end{array}$ & $\begin{array}{c}\text { Standard } \\
\text { Deviation (kW) }\end{array}$ & $\begin{array}{c}\text { Maximum (+) } \\
(\mathbf{M W})\end{array}$ & $\begin{array}{c}\text { Maximum (-) } \\
\text { (MW) }\end{array}$ \\
\hline January 2003 & 5,257 & $0.9 \%$ & 5,137 & 40.8 & $(80.6)$ \\
\hline February & 6,455 & $1.1 \%$ & 6,992 & 58.8 & $(81.1)$ \\
\hline March & 6,311 & $1.1 \%$ & 6,206 & 64.1 & $(61.8)$ \\
\hline April & 6,912 & $1.2 \%$ & 7,136 & 70.9 & $(68.6)$ \\
\hline May & 6,456 & $1.1 \%$ & 6,685 & 73.5 & $(58.1)$ \\
\hline June & 7,339 & $1.3 \%$ & 8,722 & 80.7 & $(88.8)$ \\
\hline July & 6,362 & $1.1 \%$ & 6,249 & 64.9 & $(62.6)$ \\
\hline August & 5,293 & $0.9 \%$ & 6,247 & 101.1 & $(62.8)$ \\
\hline September & 5,635 & $1.0 \%$ & 5,639 & 47.7 & $(69.6)$ \\
\hline October & 5,163 & $0.9 \%$ & 5,387 & 62.0 & $(64.6)$ \\
\hline November & 5,693 & $1.0 \%$ & 6,439 & 82.5 & $(81.7)$ \\
\hline December & 5,866 & $1.0 \%$ & 6,187 & 56.3 & $(77.5)$ \\
\hline Year & 6,053 & $1.1 \%$ & 6,501 & 101.1 & $(88.8)$ \\
\hline
\end{tabular}


APPENDIX D. Statistics of Wind Power Step Changes with 1-Hour Data Series

\begin{tabular}{|l|c|c|c|c|c|}
\hline SW Minn. & $\begin{array}{c}\text { Average } \\
\text { (MW) }\end{array}$ & $\begin{array}{c}\text { Average } \\
\text { (\% capacity) }\end{array}$ & $\begin{array}{c}\text { Standard } \\
\text { Deviation (MW) }\end{array}$ & $\begin{array}{c}\text { Maximum (+) } \\
\text { (MW) }\end{array}$ & $\begin{array}{c}\text { Maximum (-) } \\
\text { (MW) }\end{array}$ \\
\hline July 2001 & 5.6 & $5.4 \%$ & 6.5 & 31.8 & $(36.9)$ \\
\hline August & 5.8 & $5.6 \%$ & 6.4 & 33.0 & $(47.5)$ \\
\hline September & 5.2 & $5.0 \%$ & 6.1 & 32.5 & $(68.6)$ \\
\hline October & 7.1 & $6.9 \%$ & 8.4 & 66.6 & $(45.3)$ \\
\hline November & 6.7 & $6.5 \%$ & 7.8 & 42.5 & $(47.9)$ \\
\hline December & 7.5 & $6.9 \%$ & 7.7 & 49.2 & $(39.4)$ \\
\hline January 2002 & 7.4 & $7.2 \%$ & 7.4 & 40.7 & $(38.2)$ \\
\hline February & 7.2 & $6.9 \%$ & 8.5 & 81.6 & $(57.8)$ \\
\hline March & 6.3 & $6.1 \%$ & 7.4 & 59.4 & $(47.8)$ \\
\hline April & 6.9 & $6.7 \%$ & 8.3 & 58.1 & $(48.3)$ \\
\hline May & 7.3 & $7.1 \%$ & 8.7 & 59.4 & $(73.9)$ \\
\hline June & 7.2 & $6.9 \%$ & 8.3 & 45.0 & $(48.8)$ \\
\hline 12-month & 6.7 & $6.5 \%$ & 7.7 & 81.6 & $(73.9)$ \\
\hline
\end{tabular}

\begin{tabular}{|l|c|c|c|c|c|}
\hline Storm Lake & $\begin{array}{c}\text { Average } \\
\text { (MW) }\end{array}$ & $\begin{array}{c}\text { Average } \\
\text { (\% capacity) }\end{array}$ & $\begin{array}{c}\text { Standard } \\
\text { Deviation (MW) }\end{array}$ & $\begin{array}{c}\text { Maximum (+) } \\
\text { (MW) }\end{array}$ & $\begin{array}{c}\text { Maximum (-) } \\
\text { (MW) }\end{array}$ \\
\hline July 2001 & 5.0 & $4.4 \%$ & 6.1 & 50.1 & $(35.4)$ \\
\hline August & 5.5 & $4.9 \%$ & 6.9 & 45.4 & $(52.8)$ \\
\hline September & 4.9 & $4.3 \%$ & 6.3 & 47.0 & $(36.7)$ \\
\hline October & 6.6 & $5.8 \%$ & 7.4 & 54.0 & $(49.8)$ \\
\hline November & 7.3 & $6.4 \%$ & 8.0 & 53.7 & $(79.7)$ \\
\hline December & 5.9 & $4.3 \%$ & 5.6 & 24.9 & $(32.0)$ \\
\hline January 2002 & 7.1 & $6.3 \%$ & 7.6 & 40.0 & $(38.3)$ \\
\hline February & 7.5 & $6.6 \%$ & 8.8 & 80.0 & $(79.0)$ \\
\hline March & 7.2 & $6.4 \%$ & 9.4 & 72.2 & $(88.6)$ \\
\hline April & 7.4 & $6.5 \%$ & 7.9 & 47.0 & $(50.6)$ \\
\hline May & 7.4 & $6.5 \%$ & 8.8 & 54.8 & $(50.1)$ \\
\hline June & 6.7 & $5.9 \%$ & 7.7 & 44.8 & $(49.9)$ \\
\hline 12-month & 6.6 & $5.8 \%$ & 7.8 & 80.0 & $(88.6)$ \\
\hline
\end{tabular}

\begin{tabular}{|l|r|c|c|c|c|}
\hline \multicolumn{7}{|c|}{ Combined SW Minn. and Storm Lake } \\
\hline & $\begin{array}{c}\text { Average } \\
\text { (MW) }\end{array}$ & $\begin{array}{c}\text { Average } \\
\text { (\% capacity) }\end{array}$ & $\begin{array}{c}\text { Standard } \\
\text { Deviation (MW) }\end{array}$ & $\begin{array}{c}\text { Maximum (+) } \\
\text { (MW) }\end{array}$ & $\begin{array}{c}\text { Maximum (-) } \\
\text { (MW) }\end{array}$ \\
\hline July 2001 & 8.2 & $3.8 \%$ & 8.7 & 68.3 & $(47.3)$ \\
\hline August & 8.9 & $4.1 \%$ & 9.5 & 48.2 & $(62.5)$ \\
\hline September & 8.2 & $3.8 \%$ & 8.7 & 54.7 & $(60.4)$ \\
\hline October & 11.2 & $5.2 \%$ & 11.3 & 64.6 & $(63.0)$ \\
\hline November & 11.5 & $5.3 \%$ & 11.1 & 57.1 & $(79.5)$ \\
\hline December & 10.8 & $5.0 \%$ & 10.0 & 61.4 & $(37.9)$ \\
\hline January 2002 & 11.4 & $5.3 \%$ & 10.7 & 47.7 & $(65.1)$ \\
\hline February & 12.0 & $5.5 \%$ & 12.5 & 81.3 & $(78.7)$ \\
\hline March & 11.3 & $5.2 \%$ & 12.2 & 72.9 & $(91.1)$ \\
\hline April & 11.9 & $5.5 \%$ & 12.1 & 78.5 & $(72.1)$ \\
\hline May & 11.9 & $5.5 \%$ & 13.1 & 78.5 & $(104.1)$ \\
\hline June & 10.8 & $5.0 \%$ & 11.5 & 51.8 & $(81.8)$ \\
\hline 12-month & 10.7 & $4.9 \%$ & 11.2 & 81.3 & $(104.1)$ \\
\hline
\end{tabular}




\begin{tabular}{|l|c|c|c|c|c|}
\hline S Upton & $\begin{array}{c}\text { Average } \\
\text { (MW) }\end{array}$ & $\begin{array}{c}\text { Average } \\
\text { (\% capacity) }\end{array}$ & $\begin{array}{c}\text { Standard } \\
\text { Deviation (MW) }\end{array}$ & $\begin{array}{c}\text { Maximum (+) } \\
\text { (MW) }\end{array}$ & $\begin{array}{c}\text { Maximum (-) } \\
\text { (MW) }\end{array}$ \\
\hline January 2003 & 3.3 & $4.0 \%$ & 4.6 & 35.0 & $(34.0)$ \\
\hline February & 4.6 & $5.6 \%$ & 5.7 & 30.9 & $(40.3)$ \\
\hline March & 4.0 & $4.8 \%$ & 5.0 & 30.7 & $(24.2)$ \\
\hline April & 4.2 & $5.1 \%$ & 5.4 & 36.0 & $(28.8)$ \\
\hline May & 3.8 & $4.5 \%$ & 5.7 & 39.7 & $(32.6)$ \\
\hline June & 5.7 & $6.9 \%$ & 6.4 & 34.8 & $(34.4)$ \\
\hline July & 5.5 & $6.7 \%$ & 5.9 & 46.8 & $(32.8)$ \\
\hline August & 4.8 & $5.8 \%$ & 5.6 & 41.5 & $(32.0)$ \\
\hline September & 3.6 & $4.4 \%$ & 4.8 & 31.4 & $(35.3)$ \\
\hline October & 3.4 & $4.1 \%$ & 4.4 & 26.8 & $(24.9)$ \\
\hline November & 3.5 & $4.2 \%$ & 5.4 & 33.9 & $(29.6)$ \\
\hline December & 3.4 & $4.1 \%$ & 5.5 & 35.1 & $(29.2)$ \\
\hline Year & 4.0 & $4.8 \%$ & 5.4 & 46.8 & $(40.3)$ \\
\hline
\end{tabular}

\begin{tabular}{|l|c|c|c|c|c|}
\hline Trent Mesa & $\begin{array}{c}\text { Average } \\
\text { (MW) }\end{array}$ & $\begin{array}{c}\text { Average } \\
\text { (\% capacity) }\end{array}$ & $\begin{array}{c}\text { Standard } \\
\text { Deviation (MW) }\end{array}$ & $\begin{array}{c}\text { Maximum (+) } \\
\text { (MW) }\end{array}$ & $\begin{array}{c}\text { Maximum (-) } \\
\text { (MW) }\end{array}$ \\
\hline January 2003 & 9.0 & $6.0 \%$ & 10.9 & 58.8 & $(64.0)$ \\
\hline February & 8.9 & $5.9 \%$ & 11.4 & 61.1 & $(66.6)$ \\
\hline March & 10.6 & $7.1 \%$ & 12.1 & 81.2 & $(86.9)$ \\
\hline April & 10.9 & $7.3 \%$ & 12.5 & 68.9 & $(64.2)$ \\
\hline May & 10.9 & $7.3 \%$ & 13.3 & 105.8 & $(97.7)$ \\
\hline June & 11.3 & $7.5 \%$ & 15.7 & 100.4 & $(98.6)$ \\
\hline July & 9.2 & $6.1 \%$ & 9.9 & 66.4 & $(63.0)$ \\
\hline August & 7.7 & $5.1 \%$ & 11.0 & 60.4 & $(106.3)$ \\
\hline September & 7.5 & $5.0 \%$ & 9.6 & 67.4 & $(64.3)$ \\
\hline October & 8.3 & $5.5 \%$ & 10.4 & 73.0 & $(91.9)$ \\
\hline November & 7.1 & $4.7 \%$ & 9.4 & 51.5 & $(50.2)$ \\
\hline December & 8.1 & $5.4 \%$ & 11.2 & 73.7 & $(93.5)$ \\
\hline Year & 9.1 & $6.1 \%$ & 11.7 & 105.8 & $(106.3)$ \\
\hline
\end{tabular}

\begin{tabular}{|l|c|c|c|c|c|}
\hline SW Upton & $\begin{array}{c}\text { Average } \\
\text { (MW) }\end{array}$ & $\begin{array}{c}\text { Average } \\
\text { (\% capacity) }\end{array}$ & $\begin{array}{c}\text { Standard } \\
\text { Deviation (MW) }\end{array}$ & $\begin{array}{c}\text { Maximum (+) } \\
\text { (MW) }\end{array}$ & $\begin{array}{c}\text { Maximum (-) } \\
\text { (MW) }\end{array}$ \\
\hline January 2003 & 2.3 & $2.9 \%$ & 2.8 & 19.2 & $(16.3)$ \\
\hline February & 4.3 & $5.4 \%$ & 4.9 & 40.0 & $(37.2)$ \\
\hline March & 4.1 & $5.1 \%$ & 4.6 & 26.4 & $(23.6)$ \\
\hline April & 3.5 & $4.4 \%$ & 4.7 & 35.1 & $(23.2)$ \\
\hline May & 3.7 & $4.6 \%$ & 4.8 & 29.5 & $(28.0)$ \\
\hline June & 4.7 & $5.9 \%$ & 5.6 & 33.0 & $(33.0)$ \\
\hline July & 3.9 & $4.9 \%$ & 4.4 & 30.3 & $(27.9)$ \\
\hline August & 4.4 & $5.5 \%$ & 5.0 & 36.0 & $(41.6)$ \\
\hline September & 3.5 & $4.4 \%$ & 4.2 & 29.6 & $(25.5)$ \\
\hline October & 2.6 & $3.3 \%$ & 3.3 & 11.3 & $(17.7)$ \\
\hline November & 3.0 & $3.8 \%$ & 3.7 & 30.3 & $(27.4)$ \\
\hline December & 4.0 & $5.1 \%$ & 4.9 & 28.9 & $(31.5)$ \\
\hline Year & 3.7 & $4.7 \%$ & 4.6 & 40.0 & $(41.6)$ \\
\hline
\end{tabular}




\begin{tabular}{|l|c|c|c|c|c|}
\hline TWPP & $\begin{array}{c}\text { Average } \\
\text { (MW) }\end{array}$ & $\begin{array}{c}\text { Average } \\
\text { (\% capacity) }\end{array}$ & $\begin{array}{c}\text { Standard } \\
\text { Deviation (MW) }\end{array}$ & $\begin{array}{c}\text { Maximum (+) } \\
\text { (MW) }\end{array}$ & $\begin{array}{c}\text { Maximum (-) } \\
\text { (MW) }\end{array}$ \\
\hline January 2003 & & & & & \\
\hline February & & & & & \\
\hline March & & & & 24.9 & $(19.9)$ \\
\hline April & 2.6 & $7.4 \%$ & 3.1 & 16.1 & $(16.0)$ \\
\hline May & 1.9 & $5.4 \%$ & 2.5 & 20.5 & $(16.6)$ \\
\hline June & 2.6 & $7.3 \%$ & 3.1 & 12.2 & $(27.8)$ \\
\hline July & 1.5 & $4.3 \%$ & 2.2 & 20.1 & $(15.5)$ \\
\hline August & 1.8 & $5.1 \%$ & 2.3 & 24.3 & $(9.9)$ \\
\hline September & 1.6 & $4.6 \%$ & 2.1 & 29.5 & $(15.0)$ \\
\hline October & 1.6 & $4.6 \%$ & 2.5 & 2.8 & $(19.2)$ \\
\hline November & 2.2 & $6.3 \%$ & 2.7 & 2.7 & $(21.0)$ \\
\hline December & 3.2 & $9.1 \%$ & 4.1 & 23.9 & $(27.8)$ \\
\hline Year & 2.0 & $5.8 \%$ & 2.8 & 29.5 & \\
\hline
\end{tabular}

\begin{tabular}{|l|r|c|c|c|c|}
\hline \multicolumn{7}{|c|}{ Four Texas Plants Combined } \\
\hline & $\begin{array}{c}\text { Average } \\
\text { (MW) }\end{array}$ & $\begin{array}{c}\text { Average } \\
\text { (\% capacity) }\end{array}$ & $\begin{array}{c}\text { Standard } \\
\text { Deviation (MW) }\end{array}$ & $\begin{array}{c}\text { Maximum (+) } \\
\text { (MW) }\end{array}$ & $\begin{array}{c}\text { Maximum (-) } \\
\text { (MW) }\end{array}$ \\
\hline January 2003 & 9.7 & $2.8 \%$ & 11.3 & 79.9 & $(68.9)$ \\
\hline February & 13.5 & $3.9 \%$ & 13.7 & 79.2 & $(72.7)$ \\
\hline March & 14.0 & $4.0 \%$ & 13.6 & 79.6 & $(77.0)$ \\
\hline April & 14.7 & $4.3 \%$ & 15.2 & 107.3 & $(77.3)$ \\
\hline May & 13.6 & $3.9 \%$ & 14.2 & 105.1 & $(96.8)$ \\
\hline June & 16.4 & $4.7 \%$ & 18.1 & 124.9 & $(126.4)$ \\
\hline July & 14.2 & $4.1 \%$ & 12.8 & 104.5 & $(66.2)$ \\
\hline August & 12.9 & $3.7 \%$ & 13.8 & 79.8 & $(103.1)$ \\
\hline September & 11.1 & $3.2 \%$ & 11.5 & 64.4 & $(73.5)$ \\
\hline October & 10.6 & $3.1 \%$ & 11.4 & 74.5 & $(91.2)$ \\
\hline November & 11.1 & $3.2 \%$ & 12.1 & 76.5 & $(69.0)$ \\
\hline December & 13.0 & $3.8 \%$ & 13.2 & 75.5 & $(95.0)$ \\
\hline Year & 12.9 & $3.7 \%$ & 13.7 & 124.9 & $(126.4)$ \\
\hline
\end{tabular}

\begin{tabular}{|l|c|c|c|c|c|}
\hline \multicolumn{7}{|c|}{ Midwest and Texas Plants Combined } \\
\hline & $\begin{array}{c}\text { Average } \\
\text { (MW) }\end{array}$ & $\begin{array}{c}\text { Average } \\
\text { (\% capacity) }\end{array}$ & $\begin{array}{c}\text { Standard } \\
\text { Deviation (MW) }\end{array}$ & $\begin{array}{c}\text { Maximum (+) } \\
\text { (MW) }\end{array}$ & $\begin{array}{c}\text { Maximum (-) } \\
\text { (MW) }\end{array}$ \\
\hline January 2003 & 15.2 & $2.7 \%$ & 14.0 & 79.3 & $(78.2)$ \\
\hline February & 17.6 & $3.1 \%$ & 15.6 & 80.0 & $(90.5)$ \\
\hline March & 20.2 & $3.6 \%$ & 17.8 & 110.0 & $(121.9)$ \\
\hline April & 19.8 & $3.5 \%$ & 19.0 & 111.5 & $(113.0)$ \\
\hline May & 17.9 & $3.2 \%$ & 16.4 & 103.4 & $(90.3)$ \\
\hline June & 20.0 & $3.6 \%$ & 19.4 & 125.1 & $(126.5)$ \\
\hline July & 19.1 & $3.4 \%$ & 16.4 & 106.5 & $(77.7)$ \\
\hline August & 15.7 & $2.8 \%$ & 15.4 & 141.7 & $(110.0)$ \\
\hline September & 17.0 & $3.0 \%$ & 14.9 & 79.3 & $(78.2)$ \\
\hline October & 16.3 & $2.9 \%$ & 14.0 & 65.8 & $(84.8)$ \\
\hline November & 16.4 & $2.9 \%$ & 16.6 & 113.6 & $(82.0)$ \\
\hline December & 18.3 & $3.3 \%$ & 16.5 & 130.0 & $(93.3)$ \\
\hline Year & 17.7 & $3.1 \%$ & 16.5 & 141.7 & $(126.5)$ \\
\hline
\end{tabular}


APPENDIX E. Statistics of Wind Power Ramping Rates with 1-Minute Data Series

\begin{tabular}{|l|c|c|c|c|c|c|}
\hline SW Minn. & \multicolumn{2}{|c|}{ Average } & Stdev. & Avg. time & Max (+) & Max.(-) \\
\hline & (kW/min) & $(\%$ cap) & (kW/min) & (min) & (MW/min) & (MW/min) \\
\hline July 2001 & 436 & $0.4 \%$ & 488 & 3.3 & 7.2 & $(4.7)$ \\
\hline August & 411 & $0.4 \%$ & 457 & 3.0 & 8.5 & $(10.2)$ \\
\hline September & 464 & $0.3 \%$ & 474 & 3.0 & 3.9 & $(4.5)$ \\
\hline October & 552 & $0.5 \%$ & 578 & 2.7 & 6.1 & $(6.5)$ \\
\hline November & 400 & $0.4 \%$ & 427 & 2.8 & 10.6 & $(4.9)$ \\
\hline December & 413 & $0.4 \%$ & 424 & 2.9 & 6.4 & $(4.9)$ \\
\hline January 2002 & 431 & $0.4 \%$ & 432 & 3.0 & 4.0 & $(4.4)$ \\
\hline February & 456 & $0.4 \%$ & 480 & 2.5 & 7.0 & $(8.1)$ \\
\hline March & 434 & $0.4 \%$ & 499 & 2.7 & 5.4 & $(19.2)$ \\
\hline April & 548 & $0.5 \%$ & 602 & 2.6 & 6.8 & $(23.7)$ \\
\hline May & 529 & $0.5 \%$ & 587 & 2.8 & 6.7 & $(13.3)$ \\
\hline June & 598 & $0.6 \%$ & 722 & 2.9 & 7.9 & $(42.1)$ \\
\hline 12-month & 473 & $0.5 \%$ & 526 & 2.8 & 10.6 & $(42.1)$ \\
\hline
\end{tabular}

\begin{tabular}{|l|c|c|c|c|c|c|}
\hline Storm Lake & \multicolumn{2}{|c|}{ Average } & Stdev. & Avg. time & Max (+) & Max.(-) \\
\hline & (kW/min) & (\% cap) & (kW/min) & (min) & (MW/min) & (MW/min) \\
\hline July 2001 & 412 & $0.4 \%$ & 415 & 3.7 & 4.5 & $(4.2)$ \\
\hline August & 344 & $0.3 \%$ & 370 & 3.6 & 6.6 & $(5.3)$ \\
\hline September & 393 & $0.3 \%$ & 417 & 3.6 & 6.4 & $(4.1)$ \\
\hline October & 553 & $0.5 \%$ & 528 & 2.9 & 5.7 & $(4.7)$ \\
\hline November & 458 & $0.4 \%$ & 421 & 3.0 & 4.7 & $(4.5)$ \\
\hline December & 340 & $0.3 \%$ & 450 & 3.4 & 18.0 & $(2.7)$ \\
\hline January 2002 & 447 & $0.4 \%$ & 423 & 3.3 & 3.8 & $(4.2)$ \\
\hline February & 477 & $0.4 \%$ & 1,177 & 2.7 & 45.7 & $(50.4)$ \\
\hline March & 553 & $0.5 \%$ & 815 & 3.1 & 11.0 & $(45.4)$ \\
\hline April & 575 & $0.5 \%$ & 554 & 2.8 & 7.7 & $(10.3)$ \\
\hline May & 570 & $0.5 \%$ & 660 & 2.9 & 6.0 & $(32.6)$ \\
\hline June & 583 & $0.5 \%$ & 552 & 2.7 & 9.5 & $(14.0)$ \\
\hline 12-month & 492 & $0.4 \%$ & 632 & 3.1 & 45.7 & $(50.4)$ \\
\hline
\end{tabular}

\begin{tabular}{|l|c|c|c|c|c|c|}
\hline \multicolumn{7}{|c|}{ Combined SW Minn. and Storm Lake } \\
\hline & \multicolumn{2}{c}{ Average } & \multicolumn{1}{c|}{ Stdev. } & Avg. time & Max (+) & Max.(-) \\
\hline & (kW/min) & (\% cap) & (kW/min) & (min) & (MW/min) & (MW/min) \\
\hline July 2001 & 585 & $0.3 \%$ & 613 & 3.2 & 7.4 & $(10.4)$ \\
\hline August & 540 & $0.2 \%$ & 559 & 3.1 & 6.3 & $(9.2)$ \\
\hline September & 594 & $0.3 \%$ & 609 & 3.0 & 6.7 & $(5.9)$ \\
\hline October & 782 & $0.4 \%$ & 745 & 2.8 & 7.8 & $(7.3)$ \\
\hline November & 626 & $0.3 \%$ & 561 & 2.9 & 7.8 & $(4.3)$ \\
\hline December & 505 & $0.2 \%$ & 713 & 3.0 & 25.3 & $(4.5)$ \\
\hline January 2002 & 636 & $0.3 \%$ & 560 & 3.1 & 4.9 & $(4.5)$ \\
\hline February & 691 & $0.3 \%$ & 1,111 & 2.7 & 46.1 & $(49.0)$ \\
\hline March & 720 & $0.3 \%$ & 866 & 2.9 & 11.4 & $(39.4)$ \\
\hline April & 804 & $0.4 \%$ & 863 & 2.7 & 7.8 & $(46.6)$ \\
\hline May & 792 & $0.4 \%$ & 848 & 2.8 & 9.4 & $(33.1)$ \\
\hline June & 856 & $0.4 \%$ & 859 & 2.8 & 10.7 & $(42.7)$ \\
\hline 12-month & 694 & $0.3 \%$ & 773 & 2.9 & 46.1 & $(49.0)$ \\
\hline
\end{tabular}




\begin{tabular}{|l|c|c|c|c|c|c|}
\hline S Upton & \multicolumn{2}{|c|}{ Average } & Stdev. & Avg. time & \multicolumn{1}{c|}{ Max (+) } & Max.(-) \\
\hline & $(\mathbf{k W / m i n})$ & $\mathbf{( \% ~ c a p )}$ & $\mathbf{( k W / m i n})$ & (min) & (kW/min) & (kW/min) \\
\hline January 2003 & 350 & $0.4 \%$ & 452 & 3.2 & 9.0 & $(11.8)$ \\
\hline February & 433 & $0.5 \%$ & 586 & 3.2 & 27.2 & $(19.3)$ \\
\hline March & 444 & $0.5 \%$ & 608 & 2.9 & 9.5 & $(15.3)$ \\
\hline April & 442 & $0.5 \%$ & 570 & 2.4 & 7.6 & $(12.2)$ \\
\hline May & 424 & $0.5 \%$ & 581 & 6.5 & 7.6 & $(13.1)$ \\
\hline June & 498 & $0.6 \%$ & 673 & 2.6 & 12.2 & $(12.0)$ \\
\hline July & 551 & $0.7 \%$ & 566 & 2.4 & 11.7 & $(12.9)$ \\
\hline August & 469 & $0.6 \%$ & 491 & 2.6 & 7.9 & $(10.4)$ \\
\hline September & 394 & $0.5 \%$ & 472 & 2.6 & 12.3 & $(15.2)$ \\
\hline October & 337 & $0.4 \%$ & 424 & 2.9 & 9.0 & $(11.0)$ \\
\hline November & 368 & $0.4 \%$ & 481 & 2.8 & 12.0 & $(15.1)$ \\
\hline December & 389 & $0.5 \%$ & 404 & 2.7 & 8.9 & $(11.0)$ \\
\hline Year & 428 & $0.5 \%$ & 533 & 2.9 & 27.2 & $(19.3)$ \\
\hline
\end{tabular}

\begin{tabular}{|l|c|c|c|c|c|c|}
\hline Trent Mesa & \multicolumn{2}{|c|}{ Average } & Stdev. & Avg. time & Max (+) & Max.(-) \\
\hline & (kW/min) & (\% cap) & (kW/min) & (min) & (MW/min) & (MW/min) \\
\hline January 2003 & 739 & $0.5 \%$ & 806 & 2.9 & 8.4 & $(16.7)$ \\
\hline February & 936 & $0.6 \%$ & 1,049 & 2.8 & 22.4 & $(23.6)$ \\
\hline March & 982 & $0.7 \%$ & 1,111 & 2.6 & 14.4 & $(22.1)$ \\
\hline April & 1,080 & $0.7 \%$ & 1,220 & 2.4 & 14.1 & $(34.5)$ \\
\hline May & 974 & $0.6 \%$ & 1,025 & 2.6 & 12.5 & $(11.0)$ \\
\hline June & 877 & $0.6 \%$ & 974 & 2.8 & 16.1 & $(19.8)$ \\
\hline July & 789 & $0.5 \%$ & 734 & 2.8 & 21.6 & $(6.8)$ \\
\hline August & 733 & $0.5 \%$ & 789 & 3.2 & 9.1 & $(30.4)$ \\
\hline September & 806 & $0.5 \%$ & 869 & 2.6 & 11.1 & $(17.6)$ \\
\hline October & 738 & $0.5 \%$ & 855 & 2.8 & 20.0 & $(17.8)$ \\
\hline November & 855 & $0.6 \%$ & 949 & 2.4 & 13.1 & $(32.7)$ \\
\hline December & 782 & $0.5 \%$ & 904 & 2.5 & 19.0 & $(15.4)$ \\
\hline Year & 863 & $0.6 \%$ & 964 & 2.7 & 22.4 & $(34.5)$ \\
\hline
\end{tabular}

\begin{tabular}{|c|c|c|c|c|c|c|}
\hline \multirow[t]{2}{*}{ SW Upton } & \multicolumn{2}{|c|}{ Average } & \multirow{2}{*}{$\begin{array}{c}\text { Stdev. } \\
\text { (kW/min) }\end{array}$} & \multirow{2}{*}{\begin{tabular}{|c} 
Avg. time \\
(min)
\end{tabular}} & \multirow{2}{*}{$\begin{array}{c}\text { Max (+) } \\
\text { (MW/min) }\end{array}$} & \multirow{2}{*}{$\begin{array}{c}\text { Max.(-) } \\
\text { (MW/min) }\end{array}$} \\
\hline & (kW/min) & (\% cap) & & & & \\
\hline \begin{tabular}{|l|} 
January 2003 \\
\end{tabular} & 452 & $0.6 \%$ & 469 & 2.9 & 7.6 & $(7.7)$ \\
\hline February & 606 & $0.8 \%$ & 621 & 2.9 & 6.3 & (6.3) \\
\hline March & 647 & $0.8 \%$ & 775 & 2.6 & 8.2 & (7.8) \\
\hline April & 743 & $0.9 \%$ & 773 & 2.4 & 8.0 & $(13.0)$ \\
\hline May & 747 & $0.9 \%$ & 871 & 2.7 & 15.4 & (15.8) \\
\hline June & 718 & $0.9 \%$ & 786 & 2.5 & 10.3 & (14.2) \\
\hline July & 732 & $0.9 \%$ & 744 & 2.5 & 8.1 & $(8.0)$ \\
\hline August & 639 & $0.8 \%$ & 685 & 2.4 & 8.6 & (14.2) \\
\hline September & 631 & $0.8 \%$ & 655 & 2.5 & 7.1 & (12.5) \\
\hline October & 684 & $0.9 \%$ & 872 & 2.4 & 4.6 & (6.7) \\
\hline November & 541 & $0.7 \%$ & 568 & 2.6 & 8.0 & $(7.1)$ \\
\hline December & 538 & $0.7 \%$ & 559 & 2.5 & 6.4 & (7.6) \\
\hline Year & 637 & $0.8 \%$ & 698 & 2.6 & 15.4 & (15.8) \\
\hline
\end{tabular}




\begin{tabular}{|c|c|c|c|c|c|c|}
\hline TWPP & \multicolumn{2}{|c|}{ Average } & $\begin{array}{l}\text { Stdev. } \\
\text { (kW/min) }\end{array}$ & \begin{tabular}{|c} 
Avg. time \\
(min)
\end{tabular} & \begin{tabular}{|c|} 
Max (+) \\
(kW/min) \\
\end{tabular} & $\begin{array}{c}\text { Max.(-) } \\
\text { (kW/min) }\end{array}$ \\
\hline \begin{tabular}{|l} 
January $20 \mathrm{C}$ \\
\end{tabular} & & & & & & \\
\hline February & & & & & & \\
\hline March & & & & & & \\
\hline April & 384 & $1.1 \%$ & 487 & 2.4 & 6.0 & (6.2) \\
\hline May & 296 & $0.8 \%$ & 396 & 2.4 & 5.0 & $(5.8)$ \\
\hline June & 397 & $1.1 \%$ & 488 & 2.8 & 5.7 & $(9.2)$ \\
\hline July & 336 & $1.0 \%$ & 462 & 3.0 & 5.6 & $(8.0)$ \\
\hline August & 356 & $1.0 \%$ & 492 & 2.8 & 6.1 & $(4.9)$ \\
\hline September & 300 & $0.9 \%$ & 380 & 2.7 & 5.5 & (3.7) \\
\hline October & 216 & $0.6 \%$ & 263 & 2.9 & 3.8 & (3.5) \\
\hline November & 252 & $0.7 \%$ & 275 & 2.4 & 5.8 & (3.8) \\
\hline December & 271 & $0.8 \%$ & 331 & 2.5 & 7.8 & $(9.2)$ \\
\hline Year & 314 & $0.9 \%$ & 414 & 2.6 & 7.8 & $(9.2)$ \\
\hline
\end{tabular}

\begin{tabular}{|l|c|c|c|c|c|c|}
\hline \multicolumn{7}{|l|}{ Four Texas Plants Combined } \\
\hline & \multicolumn{2}{c|}{ Average } & Stdev. & Avg. time & Max (+) & Max.(-) \\
\hline & (kW/min) & (\% cap) & (kW/min) & (min) & (kW/min) & (kW/min) \\
\hline January 2003 & 845 & $0.2 \%$ & 864 & 2.9 & 8.5 & $(12.0)$ \\
\hline February & 1,185 & $0.3 \%$ & 1,272 & 2.7 & 23.3 & $(53.2)$ \\
\hline March & 1,318 & $0.4 \%$ & 1,411 & 2.5 & 14.5 & $(44.4)$ \\
\hline April & 1,523 & $0.4 \%$ & 1,420 & 2.3 & 12.3 & $(21.0)$ \\
\hline May & 1,287 & $0.4 \%$ & 1,294 & 2.4 & 14.2 & $(16.6)$ \\
\hline June & 1,356 & $0.4 \%$ & 1,365 & 2.5 & 13.5 & $(27.3)$ \\
\hline July & 1,251 & $0.4 \%$ & 1,131 & 2.4 & 21.4 & $(16.5)$ \\
\hline August & 1,157 & $0.3 \%$ & 1,079 & 2.4 & 11.2 & $(30.1)$ \\
\hline September & 1,130 & $0.3 \%$ & 1,102 & 2.4 & 11.6 & $(13.3)$ \\
\hline October & 830 & $0.2 \%$ & 894 & 2.4 & 14.7 & $(18.1)$ \\
\hline November & 1,135 & $0.3 \%$ & 1,125 & 2.3 & 13.1 & $(33.6)$ \\
\hline December & 1,086 & $0.3 \%$ & 1,076 & 2.4 & 19.7 & $(21.0)$ \\
\hline Year & 1,177 & $0.3 \%$ & 1,197 & 2.5 & 23.3 & $(53.2)$ \\
\hline
\end{tabular}

\begin{tabular}{|l|c|c|c|c|c|c|}
\hline \multicolumn{7}{|l|}{ Midwest and Texas Plants Combined } \\
\hline & \multicolumn{2}{|c|}{ Average } & Stdev. & Avg. time & Max (+) & Max.(-) \\
\hline & $(\mathbf{k W} / \mathbf{m i n})$ & $\mathbf{( \%}$ cap) & $\mathbf{( k W / m i n )}$ & $\mathbf{( m i n )}$ & $\mathbf{( k W / m i n )}$ & $\mathbf{( k W / m i n )}$ \\
\hline January 2003 & 1,055 & $0.2 \%$ & 922 & 2.6 & 8.1 & $(16.3)$ \\
\hline February & 1,380 & $0.2 \%$ & 1,507 & 2.6 & 31.5 & $(46.9)$ \\
\hline March & 1,511 & $0.3 \%$ & 1,469 & 2.6 & 24.8 & $(31.8)$ \\
\hline April & 1,749 & $0.3 \%$ & 1,622 & 2.4 & 17.3 & $(40.4)$ \\
\hline May & 1,518 & $0.3 \%$ & 1,444 & 2.5 & 23.8 & $(15.1)$ \\
\hline June & 1,564 & $0.3 \%$ & 1,510 & 2.6 & 14.8 & $(43.7)$ \\
\hline July & 1,475 & $0.3 \%$ & 1,227 & 2.5 & 23.0 & $(13.5)$ \\
\hline August & 1,271 & $0.2 \%$ & 1,160 & 2.4 & 11.2 & $(30.1)$ \\
\hline September & 1,418 & $0.3 \%$ & 1,307 & 2.4 & 12.2 & $(22.2)$ \\
\hline October & 1,108 & $0.2 \%$ & 1,057 & 2.5 & 21.0 & $(18.3)$ \\
\hline November & 1,326 & $0.2 \%$ & 1,405 & 2.4 & 33.2 & $(49.6)$ \\
\hline December & 1,285 & $0.2 \%$ & 1,424 & 2.5 & 21.8 & $(56.6)$ \\
\hline Year & 1,389 & $0.2 \%$ & 1,364 & 2.5 & 33.2 & $(56.6)$ \\
\hline
\end{tabular}




\section{APPENDIX F. Links to Related Studies}

\section{Wind Power Capacity Credit}

Milligan, M.; Kirby, B.; Jackson, K.; Shiu, H.; Makarov, Y.; Hawkins, D. (2004). California RPS Integration Study: Phase I Summary and Results; Preprint. 32 pp.; NREL Report No. CP-500-35947.

Dragoon, K.; Milligan, M. (2003). Assessing Wind Integration Costs with Dispatch Models: A Case Study of PacifiCorp; Preprint. 15 pp.; NREL Report No. CP-500-34022.

http://www.nrel.gov/docs/fy03osti/34022.pdf

Milligan, M. (2003). Wind Power Plants and System Operation in the Hourly Time Domain: Preprint. 24 pp.; NREL Report No. CP-500-33955. http://www.nrel.gov/docs/fy03osti/33955.pdf

Milligan, M. (2002). Modeling Utility-Scale Wind Power Plants, Part 2: Capacity Credit. 67 pp.; NREL Report No. TP-500-29701. http://www.nrel.gov/docs/fy02osti/29701.pdf

Milligan, M. (2002). Chronological Reliability Model Incorporating Wind Forecasts to Assess Wind Plant Reserve Allocation: Preprint. 14 pp.; NREL Report No. CP-500-32210. http://www.nrel.gov/docs/fy02osti/32210.pdf

Milligan, M. (2001). Sliding Window Technique for Calculating System LOLP Contributions of Wind Power Plants. 12 pp.; NREL Report No. CP-500-30363. http://www.nrel.gov/docs/fy01osti/30363.pdf

Milligan, M. (2001). Chronological Reliability Model to Assess Operating Reserve Allocation to Wind Power Plants: Preprint. 7 pp.; NREL Report No. CP-500-30490.

http://www.nrel.gov/docs/fy01osti/30490.pdf

Lehr, R. L.; Nielsen, J.; Andrews, S.; Milligan, M. (2001). Colorado Public Utility Commission's Xcel Wind Decision. 12 pp.; NREL Report No. CP-500-30551. http://www.nrel.gov/docs/fy01osti/30551.pdf

\section{Wind Power Characteristics}

Motta, M., Barthelmie, R.J., Vølund, P. (2004) "Stability effects on predicted wind speed profiles and power output at the Vindeby offshore wind farm". The e-WINDENG Journal. http://ejournal.windeng.net/archive/00000001/01/e-paper_motta.pdf

Westrick, K. (2004) "Strategic-Range Wind Energy Forecasting and Assessment: Methods, Benefits and Implications for Wind Energy Development in the 21st Century". Global WINDPOWER 2004 Proceedings. March 28-31, 2004. Chicago, IL.

Wan, Y.; Parsons, B.; Milligan, M. (2003). Output Power Correlation Between Nearby Wind Power Plants. Collection of the 2003 ASME Wind Energy Symposium Technical Papers at the 41st AIAA Aerospace Sciences Meeting and Exhibit, 6-9 January 2003, Reno, Nevada. New York: American Institute of Aeronautics and Astronautics, Inc. (AIAA) and American Society of Mechanical Engineers (ASME); pp. 351-356; NREL Report No. CP-500-32726. http://www.nrel.gov/docs/fy04osti/35953.pdf 
Milligan, M.; Schwartz, M.; Wan, Y. (2003). Statistical Wind Power Forecasting Models: Results for U.S. Wind Farms; Preprint . 17 pp.; NREL Report No. CP-500-33956.

http://www.nrel.gov/docs/fy03osti/33956.pdf

Landberg, L. (2003) "Measurements Related to Modeling of Large Offshore Wind Farms: Ten Years Experience”. WINDPOWER 2003 Proceedings. May 18-21, 2003. Austin, TX.

Cadogan, J.; Milligan, M.; Wan, Y.; Kirby, B. (2001). Short-Term Output Variations in Wind Farms -Implications for Ancillary Services in the United States. Wind Power for the 21st Century: The Challenge of High Wind Power Penetration for the New Energy Markets. Proceedings of the International Conference held 25-27 September 2000, Kassel, Germany (CD-ROM). Germany: WIP-Renewable Energies; 4 pp.; NREL Report No. 31084.

\section{System Impact Studies}

Milligan, M.; Kirby, B.; Jackson, K.; Shiu, H.; Makarov, Y.; Hawkins, D. (2004) California RPS Integration Study: Phase I Summary and Results; Preprint. 32 pp.; NREL Report NO. CP-500-35947. http://www.nrel.gov/docs/fy04osti/35947.pdf

Smith, C.; DeMeo, E.; Parsons, B.; Milligan, M. (2004). Wind Power Impacts on Electric Power System Operating Costs: Summary and Perspective on Work to Date; Preprint. 13 pp.; NREL Report No. CP500-35946. http://www.nrel.gov/docs/fy04osti/35946.pdf

Parsons, B.; et. al. (2003) Grid Impacts of Wind Power: A Summary of Recent Studies in the United States. Presented at the European Wind Energy Conference (EWEC), June 2003. http://www.nrel.gov/wind/pdfs/grid integration_studies_draft.pdf

Electrotek Concepts, Inc. (2003). Characterizing the Impacts of Significant Wind Generation Facilities on Bulk Power System Operations Planning Xcel Energy - North Case Study Final Report.

http://www.uwig.org/UWIGOpImpactsFinal7-15-03.pdf

Electrotek Concepts, Inc. (2003). We Energies Energy System Operations Impact of Wind Generation Integration Study. http://www.uwig.org/WeEnergiesWindImpacts FinalReport.pdf

Hirst, E. (2002) "Integrating Wind Output With Bulk-Power Operations and Wholesale Electricity Markets,” Wind Energy 5, 19-36, 2002.

Hirst, E. (2002) Integrating Wind Energy With the BPA Power System: Preliminary Study. http://www.ehirst.com/PDF/BPAWindIntegration.pdf

Hirst, E. (2001). Interactions of Wind Farms with Bulk-Power Operations and Markets , Project for Sustainable FERC Energy Policy, Alexandria, VA. http://www.ehirst.com/PDF/WindIntegration.pdf

Hirst, E. and Kirby, B. (2000) "Measuring Generator Performance in Providing the Regulation and LoadFollowing Ancillary Services”, ORNL TM/2000-383, Oak Ridge National Laboratory, Oak Ridge, TN, December 2000. 
Hirst, E. and Kirby, B. (1998) "Unbundling Generation and Transmission Services for Competitive Electricity Markets: Examining Ancillary Services”, NRRI 98-05, National Regulatory Research Institute, Columbus, OH, January 1998.

Hirst, E. and Kirby, B. (1996) “Ancillary-Service Details: Regulation, Load Following, and Generator Response". ORNL/CON-433, Oak Ridge National Laboratory, Oak Ridge, TN, September 1996. 


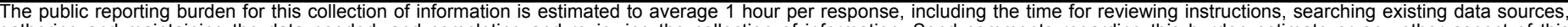

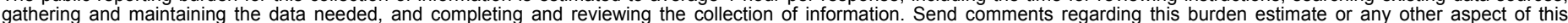

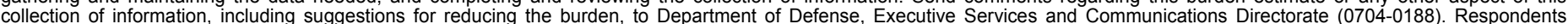

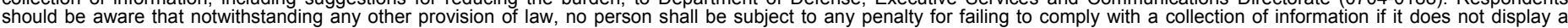

should be aware that notwithstanding

PLEASE DO NOT RETURN YOUR FORM TO THE ABOVE ORGANIZATION.

\begin{tabular}{l|l|l|l} 
1. REPORT DATE $(D D-M M-Y Y Y Y)$ & 2. REPORT TYPE & 3. DATES COVERED (FrOm - TO)
\end{tabular}

September 2004

Technical Report

4. TITLE AND SUBTITLE

Wind Power Plant Behaviors: Analysis of Long-Term Wind Power

Data

6. AUTHOR(S)

Yih-Huei Wan 5a. CONTRACT NUMBER

DE-AC36-99-G010337

5b. GRANT NUMBER

5c. PROGRAM ELEMENT NUMBER

5d. PROJECT NUMBER

NREL/TP-500-36551

5e. TASK NUMBER

WER4.4001

5f. WORK UNIT NUMBER

7. PERFORMING ORGANIZATION NAME(S) AND ADDRESS(ES)

National Renewable Energy Laboratory

1617 Cole Blvd.

Golden, CO 80401-3393

9. SPONSORING/MONITORING AGENCY NAME(S) AND ADDRESS(ES)
8. PERFORMING ORGANIZATION REPORT NUMBER

NREL/TP-500-36551
10. SPONSOR/MONITOR'S ACRONYM(S) NREL

11. SPONSORING/MONITORING AGENCY REPORT NUMBER

12. DISTRIBUTION AVAILABILITY STATEMENT

National Technical Information Service

U.S. Department of Commerce

5285 Port Royal Road

Springfield, VA 22161

\section{SUPPLEMENTARY NOTES}

14. ABSTRACT (Maximum 200 Words)

The wind industry's growth is hampered by many market barriers, some of which stem from utilities' lack of experience with the technology. The effects of wind power fluctuations on power system operations and requirements of ancillary services for wind power have increasingly become concerns for many electric utilities and wind power developers. To rememdy the situation, NREL has undertaken a project to record long-term, high-resolution wind power output data from large wind power plants in various regions.

15. SUBJECT TERMS

wind power plants; market barriers; ancillary services;

16. SECURITY CLASSIFICATION OF:
\begin{tabular}{|l|l|l|}
\hline a. REPORT & b. ABSTRACT & c. THIS PAGE \\
Unclassified & Unclassified & Unclassified \\
& & \\
\hline
\end{tabular}

\begin{tabular}{|c|c|}
\hline $\begin{array}{l}\text { 17. LIMITATION } \\
\text { OF ABSTRACT }\end{array}$ & $\begin{array}{l}\text { 18. NUMBER } \\
\text { OF PAGES }\end{array}$ \\
\hline UL & \\
\hline
\end{tabular}

19a. NAME OF RESPONSIBLE PERSON

19b. TELEPONE NUMBER (Include area code) 